RAFAEL IVENS DA SILVA BUENO

\title{
APROVEITAMENTO DA AREIA GERADA EM OBRA DE DESASSOREAMENTO - CASO: RIO PARAIBUNA / SP
}

\author{
Dissertação apresentada à Escola \\ Politécnica da Universidade de São \\ Paulo como requisito à obtenção do \\ título de Mestre em Engenharia
}

SÃO PAULO 


\title{
APROVEITAMENTO DA AREIA GERADA EM OBRA DE DESASSOREAMENTO - CASO: RIO PARAIBUNA / SP
}

\begin{abstract}
Dissertação apresentada à Escola Politécnica da Universidade de São Paulo como requisito à obtenção do título de Mestre em Engenharia
\end{abstract}

Área de Concentração:

Engenharia Mineral

Orientador: Prof. Dr.

José Renato Baptista de Lima

SÃO PAULO 
Este exemplar foi revisado e alterado em relação à versão original, sob responsabilidade única do autor e com a anuência de seu orientador.

São Paulo, de fevereiro de 2010.

Assinatura do autor

Assinatura do orientador

FICHA CATALOGRÁFICA

Bueno, Rafael Ivens da Silva

Aproveitamento da areia gerada em obra de desassoreamento - caso: Rio Paraibuna/SP / R.I.S. Bueno. -- ed.rev. -- São Paulo, 2010.

$109 \mathrm{p}$.

Dissertação (Mestrado) - Escola Politécnica da Universidade de São Paulo. Departamento de Engenharia de Minas e de Petróleo.

1. Areia (Extração) 2. Resíduos sólidos (Recuperação) 3. Dragagem (Planejamento) I. Universidade de São Paulo. Escola Politécnica. Departamento de Engenharia de Minas e de Petróleo II. t. 


\section{DEDICATÓRIA}

A Deus,

aos meus pais Celso, Isabel, irmãos Renan, Rafaela

e à Camila 


\section{AGRADECIMENTOS}

Agradeço, em primeiro lugar, a Deus que me deu condições de estudar e realizar mais este trabalho.

Aos meus pais Celso da Silva Bueno e Isabel Christina da Silva Bueno, ambos de extrema importância em minha vida, sempre me apoiando e confiando em minha pessoa com todo o carinho e amor.

Ao professor Dr. José Renato Baptista de Lima pela orientação e pelo constante estímulo transmitido durante todo o trabalho.

Aos professores Dr. Lindolfo Soares e Dra. Silvia Selmo pela indicação e possibilidades de execução das complementações deste trabalho.

Ao professor Dr. Henrique Kahn Coordenador do LCT - Laboratório de Caracterização Tecnológica e aos pesquisadores Dra. Maria Manuela Tassinari, Freud S. Campbell e André Borges Braz pela oportunidade e apoio.

Ao professor Alex Thaumaturgo Dias Chefe do Departamento de Engenharia Civil, Ambiental e Sanitária da Universidade de Taubaté disponibilizando retorno ao departamento para a minha formação profissional.

Ao professor Antônio Cláudio e estagiário Luiz Fernando Pereira do Laboratório de Mecânica dos Solos do Departamento de Engenharia Civil, Ambiental e Sanitária da Universidade de Taubaté.

À todos aqueles que, direta ou indiretamente, colaboraram para que este trabalho atingisse os objetivos propostos. 


\section{RESUMO}

Em decorrência do assoreamento do leito do Rio Paraibuna, no município de Paraibuna/SP, a captação de água para a Estação de Tratamento de Águas (ETA) desse município vem enfrentando problemas com a sucção de areia e outros detritos, fato este que diminui a capacidade de captação e aumenta o desgaste de equipamentos. No presente caso, o problema de assoreamento caracteriza uma situação emergencial em virtude do risco iminente de paralisação das bombas na ETA e, consequentemente, do serviço público essencial de distribuição de água potável para o município. Em 2008, o volume de areia acumulado próximo à área de captação de água era tão elevado que foram formados verdadeiros "bancos de areia", prejudicando o abastecimento da cidade, que necessita da captação de 200 litros de água por segundo. Desta forma, fez-se necessário o desenvolvimento do plano de desassoreamento do leito do rio Paraibuna, sendo este avaliado em conjunto com a viabilidade ambiental e econômica da implantação de atividade de explotação de areia como agregado para Construção Civil, na busca de sustentabilidade para tal obra, uma vez que se admite a possibilidade de minimização do impacto ambiental ao desenvolvê-lo em área já degradada. $\mathrm{A}$ realização de uma pesquisa mineral mostra-se necessária para viabilização da implantação de um empreendimento minerário, juntamente com a avaliação das técnicas utilizadas no beneficiamento e na lavra aplicados na atividade de explotação de areia no local. Os resultados obtidos nesta pesquisa indicaram que a caracterização granulométrica está situada entre areia média à fina, nas análises por peneiramento. Também foi observado um considerável nível de impurezas orgânicas no sedimento, e nas análises de composição mineralógica, a predominância de quartzo, além de rutilo, muscovita, microclínio, albita e a possível presença de goethita. Por estas análises foi possível concluir que esta areia tem potencial para aproveitamento industrial. 


\begin{abstract}
As a result of a silting up of the riverbed of the Paraibuna river, the water capitation for the water treatment plants (WTP) of the city have been facing problems with the sand and other debris suction, fact that diminishes the capitation capacity and increases the equipment consuming. In the present case, the problem characterizes an urgent situation in virtue of the imminent risk of stoppage of the bombs in the WTP and, consequently, of the essential public service of drinking waters distribution for the city. The development of a plan of sand and silt removal in the riverbed of the Paraibuna river has became necessary. In this study it is being evaluated in set with the environmental and economic viability of sand exploitation for construction. A part from the sustainability, it also admits the possibility of reducing the environment impact if developed in area already degraded. The development of a mineral research revealed necessary to make possible the implantation of a mineral enterprise. The results showed that the particle size distribution is situated of a fine to medium sand in the sieving analyses. It was also observed considered level of organic impurities in the sediment and the analyses of mineral composition the quartz predominance beyond rutile, muscovite, microcline, albite and the possible presence of goethite. As a result, it concludes that the sand has a potential and economical evaluation and it can be used in industrial applications.
\end{abstract}




\section{LISTA DE ILUSTRAÇÕES}

Figura 1 - Localização da área de estudo na APA da Bacia do Rio Paraíba do Sul.16 Figura 2 - Localização do trecho do Rio Paraibuna.............................................18

Figura 3 - Ambientes geológicos propícios à extração de areia. ............................27

Figura 4 - Mineração de areia: lavra por dragagem em leito de rio. ........................30 Figura 5 - Mineração de areia: fluxo de operações por dragagem hidráulica em leito de rio.

Figura 6 - Zoneamento ambiental para mineração de areia no Rio Paraíba do Sul (Trecho Jacareí).

Figura 7 - Zoneamento ambiental para mineração de areia no Rio Paraíba do Sul (Trecho Caçapava)

Figura 8 - Situação de implantação da recuperação em geral no trecho Jacareí à Pindamonhangaba.

Figura 9 - Qualidade de recuperação vegetal no trecho Jacareí à Pindamonhangaba. 43

Figura 10 - Atividade de extração de areia. 44

Figura 11 - Ampliação do Mapa geológico do Estado de São Paulo na área de estudo. 48

Figura 12 - Imagem de Satélite dos Reservatórios da região de estudo. 50

Figura 13 - Localização da Bacia do Rio Paraibuna. .51

Figura 14 - Trecho do Rio Paraibuna, área de estudo. (20/08/08) 61

Figura 15 - Trecho do Rio Paraibuna, ponto de captação de água. $(20 / 08 / 08)$........61

Figura 16 - Localização dos pontos de retirada de amostras. 63

Figura 17 - Série de peneiras de abertura de malhas. 66

Figura 18 - Localização das seções de batimetria e sondagens no Rio Paraibuna..71

Figura 19 - Detalhe das seções de batimetria e sondagens. .72

Figura 20 - Curva granulométrica amostra 7D...............................................75

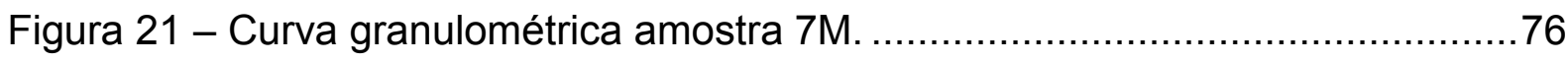

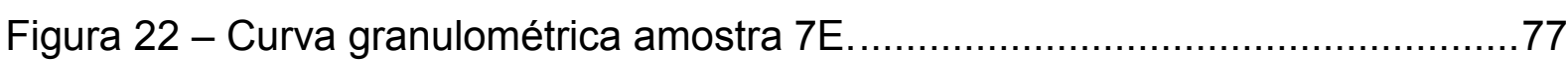

Figura 23 - Curva granulométrica amostra 8D............................................. 78

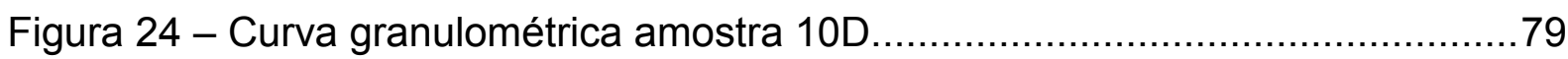

Figura 25 - Curva granulométrica amostra 10M. ............................................. 80 


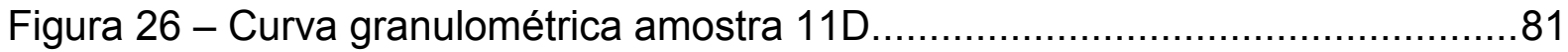

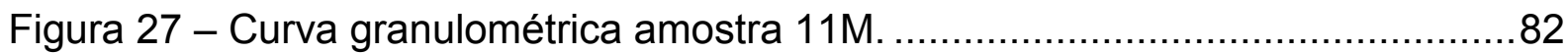

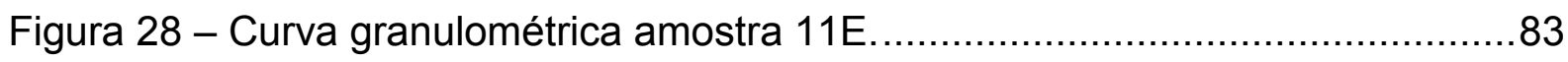

Figura 29 - Comparação das curvas granulométricas........................................ 84

Figura 30 - Resultados do ensaio de impurezas orgânicas. (30/09/09)...................86

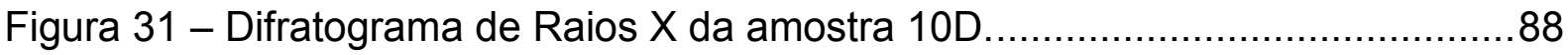

Figura 32 - Fases identificadas no difratograma de Raios $X$ da amostra 10D..........88

Figura 33 - Fluxograma conceitual da dragagem no leito do Rio Paraibuna............92

Figura 34 - Fluxograma da Estimativa do Balaço de Massa Preliminar. ...................93

\section{LISTA DE TABELAS}

Tabela 1 - Limites da distribuição granulométrica do agregado miúdo....................23

Tabela 2 - Faturamento da Produção Nacional de Areia.........................................34

Tabela 3 - Situação dos portos de areia do Vale do Paraíba ...................................43

Tabela 4 - Análise Granulométrica amostra 7D ..................................................75

Tabela 5 - Análise Granulométrica amostra 7M ............................................76

Tabela 6 - Análise Granulométrica amostra 7E ……......................................77

Tabela 7 - Análise Granulométrica amostra 8D ............................................... 78

Tabela 8 - Análise Granulométrica amostra 10D ............................................. 79

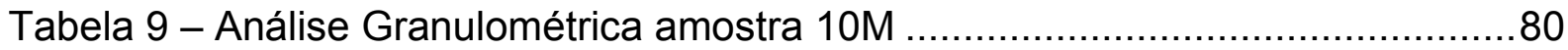

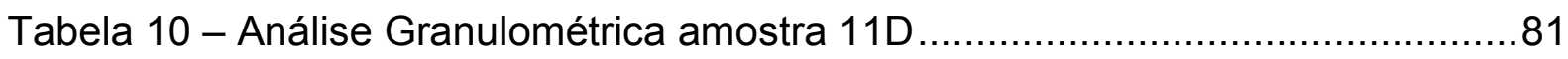

Tabela 11 - Análise Granulométrica amostra 11M ...........................................82

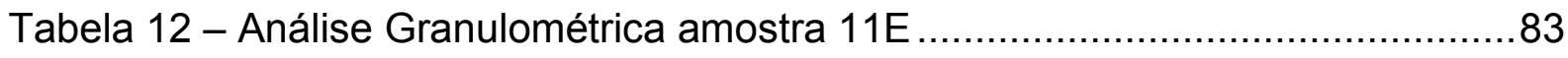

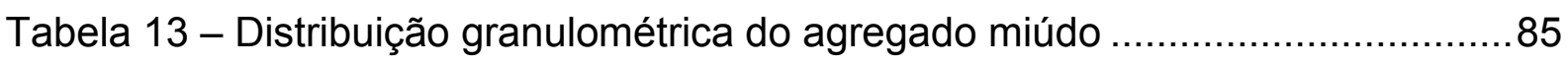

Tabela 14 - Resultados quantitativos de composição química pela fluorescência de

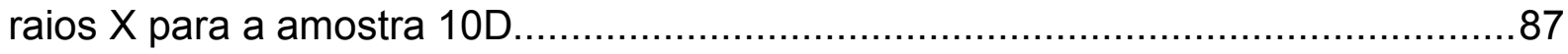

Tabela 15 - Resultados da Difratometria de raios X para a amostra 10D ...............87 
ABNT

AMAVALES

Baixada Santista

ANAMACO

Construção

APA

APP

CBP

CESP

CETESB

CONAMA

CPRM

DEPRN

DER

DERSA

DMC

DNPM

DRX

EPUSP

ETA

FRX

IPT

LCT
Associação Brasileira de Normas Técnicas

Associação dos Mineradores de Areia do Vale do Ribeira e

Associação Nacional dos Comerciantes de Material de

Área de Proteção Ambiental

Área de Proteção Permanente

Ciclo Básico de Produção

Companhia Energética de São Paulo

Companhia de Tecnologia de Saneamento Ambiental

Conselho Nacional de Meio Ambiente

Companhia de Pesquisa de Recursos Minerais

Departamento Estadual de Proteção dos Recursos Naturais

Departamento de Estradas de Rodagem

Desenvolvimento Rodoviário S.A.

Dimensão Máxima Característica

Departamento Nacional de Produção Mineral

Difração de Raios X

Escola Politécnica da Universidade de São Paulo

Estação de Tratamento de Água

Fluorescência de Raios $X$

Instituto de Pesquisas Tecnológicas do Estado de São Paulo

Laboratório de Caracterização Tecnológica da Escola

Politécnica da Universidade de São Paulo

MF Módulo de Finura

NBR Normas Brasileiras da ABNT

NM Norma Mercosul

Pamb Polícia Ambiental

RAA Reação Álcali-agregado

SINDUSCON-SP Sindicato da Indústria da Construção Civil do Estado de São Paulo 
SMA

UGRHI

UNITAU

USP

UTG
Secretaria do Meio Ambiente do Estado de São Paulo Unidade de Gerenciamento de Recursos Hídricos Universidade de Taubaté

Universidade de São Paulo

Unidade de Tratamento de Gás 


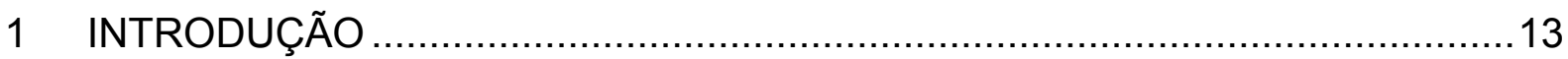

2 REVISÃO BIBLIOGRÁFICA PARA O ESTUDO-DE-CASO …..........................16

2.1 Localização da Área de Estudo ..........................................................16

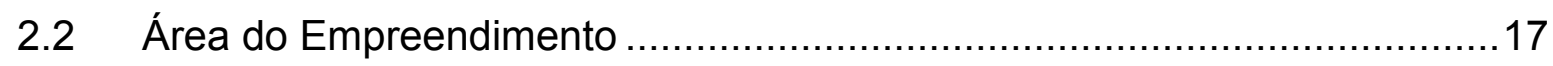

$2.3 \quad$ Planejamento de Empreendimentos ................................................ 18

2.4 Aspectos Sócio-econômicos e Ambientais ……....................................19

2.5 Operações Unitárias Características da Explotação Mineral ......................20

2.6 Agregados para Construção Civil .......................................................21

2.7 Classificação de Areia e Cascalho para Construção Civil...........................22

2.8 Reações Álcali-Agregado..................................................................24

2.8.1 Ensaios Propostos para Prever e Diagnosticar as Reações Álcali-

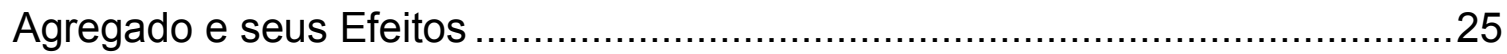

2.9 Formas de Ocorrência dos Depósitos de Areias Naturais ........................26

2.10 Quantificação e Qualificação dos Depósitos Naturais................................27

2.11 Extração de Areia em Leitos Submersos ...............................................28

2.11.1 Dragagem Hidráulica em Leitos Submersos...................................28

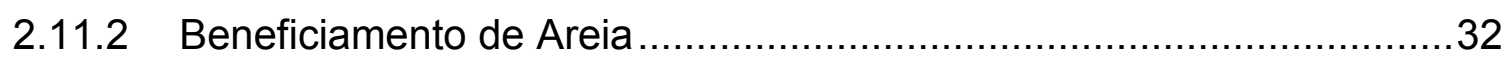

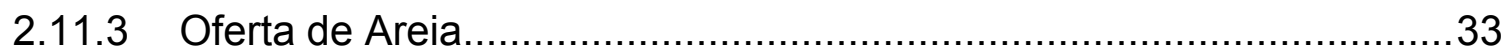

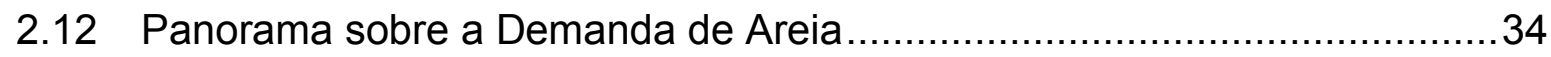

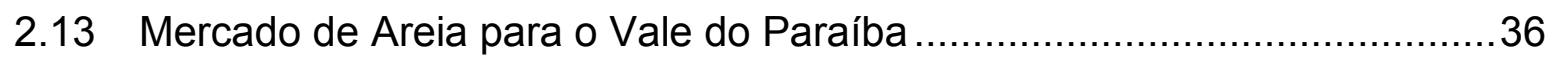

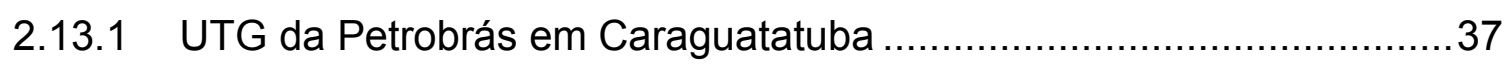

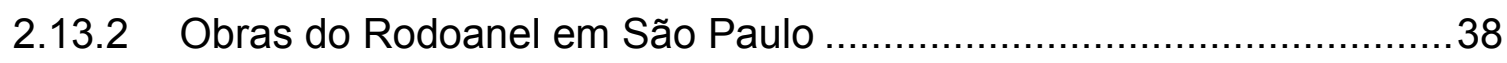

2.14 Zoneamento Ambiental Minerário do Vale do Paraíba..................................39

2.15 Premissas Legais e Sociais das Obras de Desassoreamento .....................44

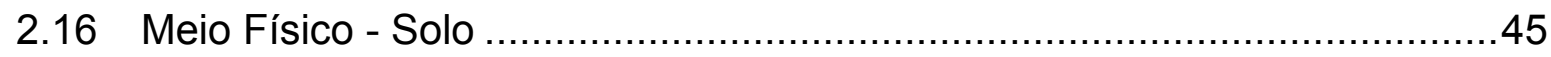

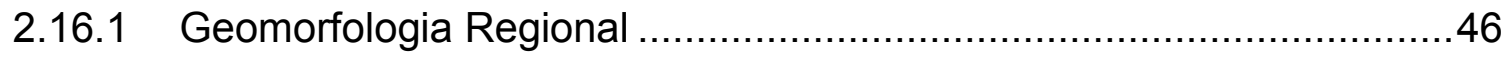

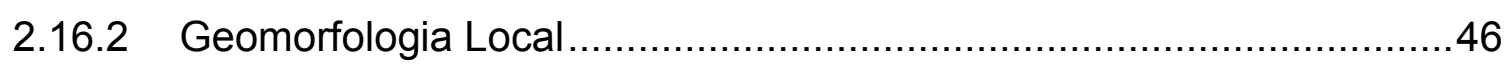

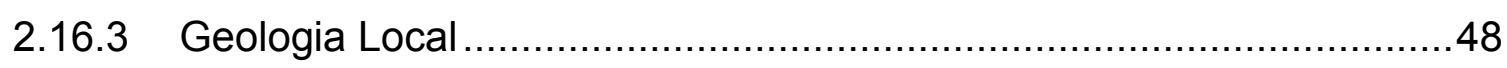

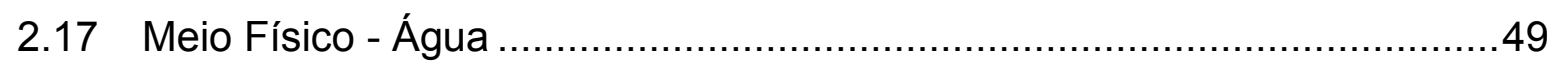

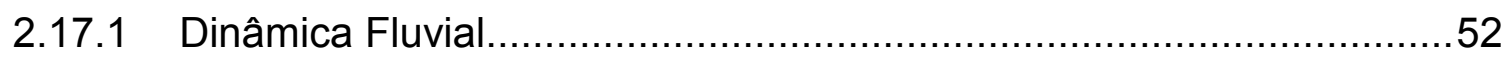

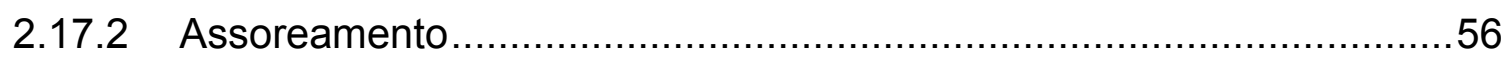


2.18 Características da Atividade de Mineração de Areia no Vale do Paraíba...57

2.19 Impactos Ambientais .......................................................................... 58

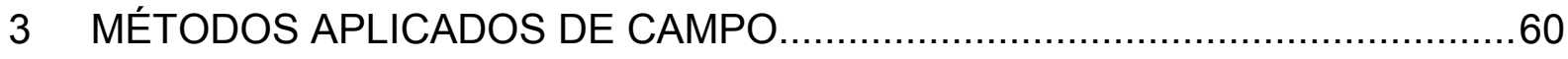

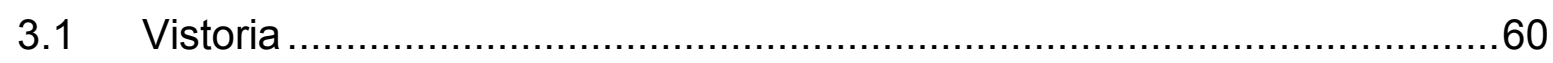

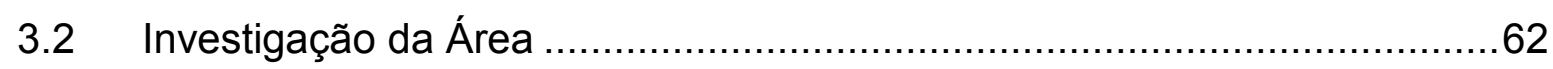

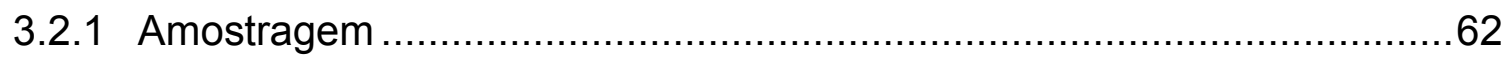

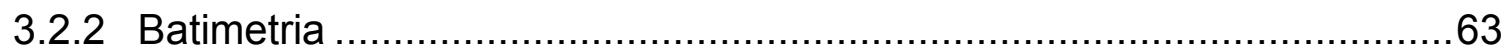

3.3 Caracterização Tecnológica Preliminar...............................................65

3.3.1 Análise Física - Peneiramento e Sedimentação .................................65

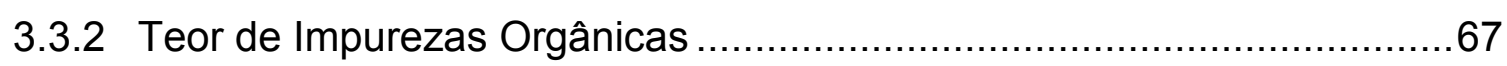

3.3.3 Análise Química - Fluorescência de Raios X...................................68

3.3.4 Composição Mineralógica - Difração de Raios X...............................68

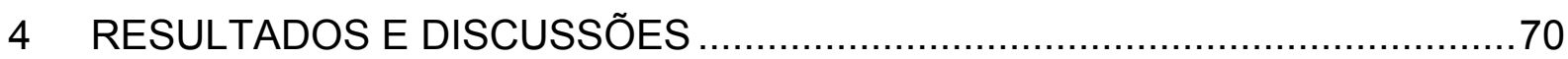

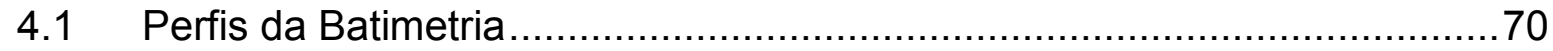

4.2 Determinação do Volume de Areia ........................................................ 73

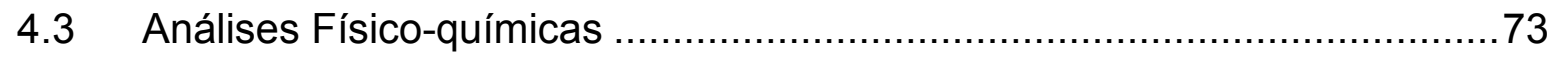

4.3.1 Análise Física - Peneiramento e Sedimentação .................................74

4.3.2 Teor de Impurezas Orgânicas ..................................................... 86

4.3.3 Análise Química - Fluorescência de Raios X.................................. 87

4.3.4 Composição Mineralógica - Difração de Raios X..............................87

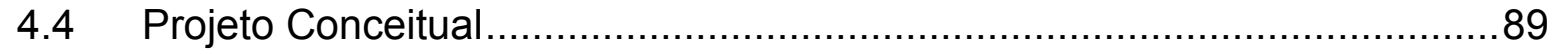

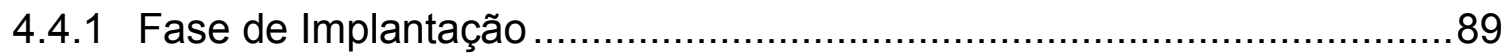

4.4.2 Fase de Operação ............................................................... 89

4.4.3 Estimativa do Balaço de Massa Preliminar ..................................... 92

4.4.4 Medidas Mitigadoras ............................................................ 93

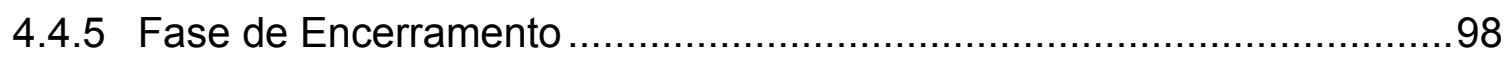

5 CONSIDERAÇÕES PARA A EXPLOTAÇÃO ........................................99

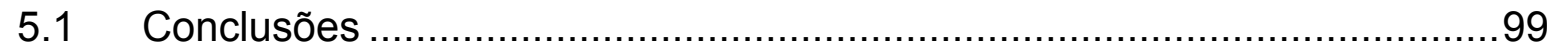

5.2 Recomendações para Explotação ................................................. 101

5.3 Estudos Complementares quanto à Qualidade da Areia .......................102

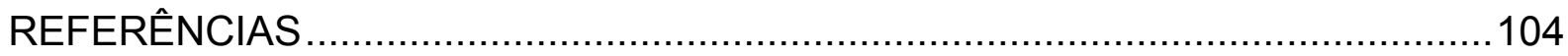




\section{INTRODUÇÃO}

O setor mineral, uma das bases da economia brasileira, faz uso intensivo de recursos naturais não-renováveis e apesar dos problemas causados ao meio ambiente, a mineração é essencial para a humanidade. Os valores socioeconômicos, como a busca por qualidade de vida e desenvolvimento sustentável, são fundamentais. Neste sentido, é um desafio para a indústria mineral reduzir as interferências no meio ambiente para níveis toleráveis, nos seus diferentes estágios de explotação (produção utiliza de seus recursos minerais) e da disposição de rejeitos e resíduos.

A lavra de um recurso natural provoca modificações no meio ambiente que podem e devem ser minimizadas, sendo necessária a recuperação da área degradada.

Esta recuperação deve ser entendida como a reincorporação da área à paisagem local e não como retorno da área à situação encontrada antes da mineração, o que seria virtualmente impossível de ocorrer.

O desenvolvimento econômico e social surge da busca da satisfação das necessidades do homem. Para que isto ocorra o planejamento é uma etapa fundamental. Este planejamento emprega diversos instrumentos para promover um desenvolvimento esperado, dentro dos quais um estudo de viabilidade busca otimizar o uso dos recursos minerais às necessidades humanas, aumentando a reserva e atendendo a função social de maximizar a extração, evitando desperdícios.

As relações entre os recursos minerais e sua sustentabilidade são facilmente mal interpretadas pela sociedade, uma vez que são recursos naturais cuja renovação em longo prazo diverge com o tempo de utilização humana.

Admite-se que a renovabilidade destes recursos pode estar muitas vezes ligadas ao planejamento e gerenciamento das atividades impactantes, independente de suas proporções, como é o caso da extração mineral.

Dentre as substâncias minerais mais comumente produzidas e relacionadas com o consumo doméstico, as principais são aquelas utilizadas como agregado na Construção Civil. Tratam-se de minerais cuja produção está intimamente ligada ao desenvolvimento dos centros urbanos, resultando na grande movimentação de matérias-primas e elevados valores de produção. 
Os agregados são os materiais de construção mais utilizados no mundo. Quando se reporta o estado de São Paulo e a Região Metropolitana de São Paulo, para fim de comparação, o consumo per capita avança para 3,5 t/hab.ano e 4,2 t/hab.ano, respectivamente (SERNA et. al., 2008).

Em particular, na região do Vale do Paraíba, o setor mineral tem participação singular na estruturação do desenvolvimento econômico e social, como fornecedor de matérias-primas para essa região e entorno, com produtos para a Construção Civil entre outros setores industriais. A areia se destaca como o recurso mineral mais amplamente produzido no Vale do Paraíba, respondendo, hoje por $5 \%$ da produção do Brasil.

A mineração de agregados para a Construção Civil gera grandes volumes de produção, apresenta beneficiamento simples, baixo preço unitário e necessita ser realizada no entorno do local de consumo, geralmente em áreas urbanas, devido à alta participação do transporte no custo final. O setor de agregados é o segmento da indústria mineral que comporta o maior número de empresas e trabalhadores, e o único a existir em todos os estados brasileiros.

A realização de uma pesquisa mineral mostra-se necessária para a viabilização da implantação de um empreendimento minerário, especialmente quando se admite a possibilidade de minimização do impacto ambiental ao desenvolvê-lo em área já degradada.

Segundo a CALDERADO ${ }^{1}$, em 2008 o volume de areia acumulada próximo à área de captação de água era tão elevado que foram formados verdadeiros "bancos de areia", prejudicando o abastecimento da cidade, que necessita da captação de 200 litros de água por segundo.

A intensificação do processo de assoreamento está relacionada à ação antrópica ao longo da zona urbana no município pela ocupação desordenada e o controle operacional da barragem Paraitinga/Paraibuna pela CESP - Companhia Energética de São Paulo, que através do vertedouro regula a vazão causando alterações no regime do rio e intensidade do fluxo e volume de água.

Em decorrência do assoreamento do leito do Rio Paraibuna, a captação d'água para a Estação de Tratamento Águas do Município de Paraibuna vem enfrentando problemas com sucção de areia e outros detritos, fato este que diminui

\footnotetext{
${ }^{1}$ CALDERADO, C.A., funcionário da Prefeitura Municipal de Paraibuna Comunicação Pessoal, 2008.
} 
a capacidade de captação e aumenta o desgaste de equipamentos. Com isto, é importante destacar que o serviço público essencial de distribuição de água potável corre o risco de paralisação.

Este trabalho tem como objetivo avaliar a viabilidade ambiental e econômica da implantação de atividade de explotação de areia como agregado para Construção Civil, de forma conjunta ao desenvolvimento do plano de desassoreamento no leito do rio Paraibuna, município de Paraibuna localizado na região do Vale do Paraíba, interior do estado de São Paulo.

Desta forma este trabalho procura justificar a necessidade emergencial da obra de desassoreamento num trecho de 700 m de extensão do Rio Paraibuna, uma vez que se encontra junto à captação de água, comprometendo o sistema de abastecimento público e visa caracterizar a qualidade do material sedimentado nesse trecho do rio.

Verificar a viabilidade de aproveitamento da areia contida nesse sedimento, considerando os aspectos ambientais e econômicos, das operações de desassoreamento. E definir as técnicas passíveis de serem utilizadas na lavra e beneficiamento para a explotação de areia no rio Paraibuna, no trecho assoreado. 


\section{REVISÃO BIBLIOGRÁFICA PARA O ESTUDO-DE-CASO}

\subsection{Localização da Área de Estudo}

A represa do Rio Paraibuna compõe o sistema ecológico da CESP, juntamente com um horto e um viveiro de aves. É bastante propícia aos esportes náuticos e à pesca, embora seja preciso licença de pesca fornecida pelo IBAMA para realizá-la.

Passa por dentro da APA - Área de Proteção Ambiental da Bacia do Rio Paraíba do Sul que abrange uma área de preservação com 367.000 ha, criada em 1982, conforme Figura 1 a seguir.

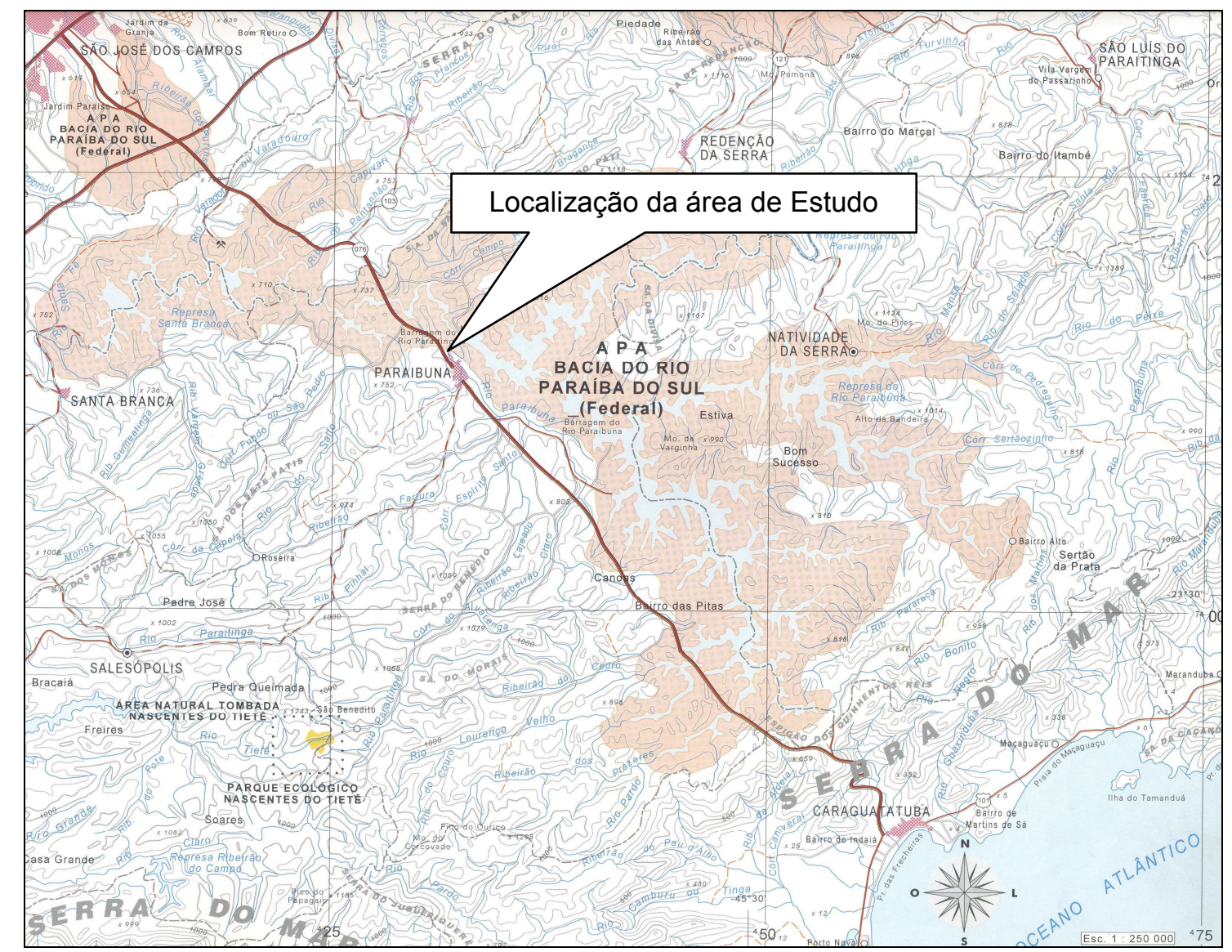

Figura 1 - Localização da área de estudo na APA da Bacia do Rio Paraíba do Sul.

Fonte: Atlas das Unidades de Conservação Ambiental do Estado de São Paulo (1998) - modificado.

A região onde se localiza o trecho de rio pesquisado é formada por "mar de morros" e está ocupada predominantemente por pastagens, por algumas áreas de reflorestamento de eucalipto e por diversas "manchas" de mata nativa. 
A vegetação arbórea nativa aparece na região formando manchas que correspondem a remanescentes de formação vegetal original da região. Na sua grande maioria, tais manchas caracterizam-se como vegetação secundária e encontram-se em estágio de regeneração, que varia entre inicial e médio.

A rota dos caminhões para o escoamento do minério gerado pela obra de desassoreamento será a mesma utilizada para o acesso ao pátio de manobras, sendo que a partir da Avenida São José o minério será distribuído no município de Paraibuna ou transportado até o Litoral Norte, através da Rodovia dos Tamoios.

\section{2 Área do Empreendimento}

O trecho do rio, alvo da extração mineral, visando o seu desassoreamento, compreende uma extensão de $700 \mathrm{~m}$, o qual foi investigado para determinar o volume do acúmulo de material sedimentado.

O local avaliado encontra-se em um trecho do rio Paraibuna, que caracteriza-se por duas curvas do rio para a direita, até $100 \mathrm{~m}$ de distância à montante da ponte da Rodovia dos Tamoios, que passa sobre o rio Paraibuna, na área urbana do município. A Figura 2 demonstra o mapa topográfico e a direção do fluxo do rio Paraibuna. 


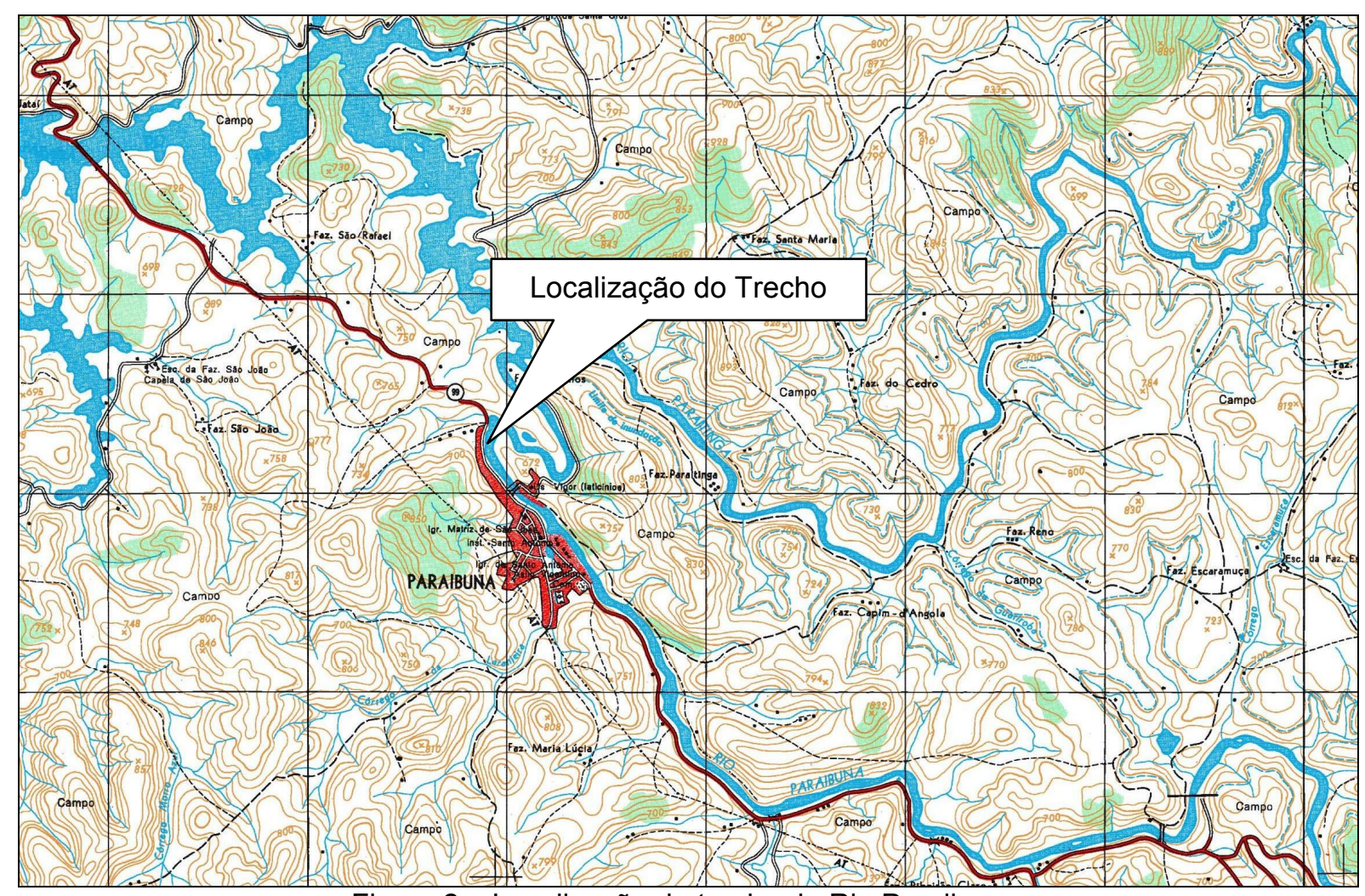

Figura 2 - Localização do trecho do Rio Paraibuna.

Fonte: Folha IBGE SF-23-Y-D-II-4 Paraibuna 1:50.000 (1973) - modificado.

\subsection{Planejamento de Empreendimentos}

Segundo o IPT (2005), os empreendimentos de mineração podem variar com relação ao método de lavra, às etapas de beneficiamento, à escala de produção e à forma de recuperação ambiental. Esta diversidade de modalidades de empreendimentos depende, basicamente, do tipo de substância mineral a ser lavrada, dos controles geológicos e das dimensões da jazida e da escala do investimento.

De forma geral, podem ser estabelecidos alguns referenciais técnicos comuns às minerações e que são importantes para uma condução adequada do desenvolvimento de uma mina, garantindo o retorno financeiro do investimento e o satisfatório controle ambiental da área minerada.

Antes do início de suas atividades, todo o empreendimento minerário requer um projeto de mineração, do qual fazem parte os estudos de quantificação, distribuição espacial e qualificação da jazida, métodos de lavra e beneficiamento a serem implementados, evolução temporal da mina, escalas de produção previstas, 
viabilidade econômica, procedimentos de controle e recuperação ambiental, implantação de infra-estrutura e sistema de apoio.

$\mathrm{Na}$ fase de operação da mina, entretanto, é importante reavaliar, de maneira sistemática, as premissas estabelecidas no projeto de mineração, adequando o ciclo produtivo, nas suas diversas dimensões técnica, econômica e ambiental à realidade das novas informações geradas durante a lavra. O planejamento e o controle operacional da mina conduzem às condições propícias para a otimização do processo produtivo, a manutenção da qualidade das substâncias minerais comercializadas, a garantia do retorno financeiro e a redução e/ou o controle de impactos ambientais.

\subsection{Aspectos Sócio-econômicos e Ambientais}

Minerar é uma das atividades mais primitivas exercidas pelo homem como fonte de sobrevivência e produção de bens industriais. A forma de extrair os bens minerais que a natureza oferece tem sido constantemente aprimorada. Como atividade extrativa, a mineração, quando exercida sem técnicas adequadas e sem controle, pode deixar um quadro de degradação oneroso na área em que se desenvolve. A atividade mineral requer, para seu êxito, cuidadoso planejamento que vai do conhecimento efetivo da situação à adoção de tecnologias atuais e aplicáveis ao caso específico, por uma equipe qualificada à recuperação da área minerada em condições recomendadas.

O bem mineral extraído não retorna mais ao local, mas pode ficar em circulação, servindo ao homem e às suas necessidades. Este aspecto traz consigo uma questão indefinida, pois se, de certa maneira, a mineração degrada o terreno, é verdade também que este ambiente pode ser reestruturado de forma aceitável, limitando o impacto ambiental negativo a um curto período de tempo e a um espaço pequeno e delimitado.

Segundo BITAR, FORNASARI e VASCONCELOS (1988), no processo extrativo, a restauração da área é algo impossível de acontecer, pois restaurar significa reproduzir as condições exatas do local, tais como eram antes de alteradas. A reabilitação parece ser a resposta mais próxima da realidade, porque a reabilitação está ligada à idéia de uso e ocupação do solo, predefinida de acordo com um projeto de reutilização do local minerado: lazer, residencial, industrial, entre 
outros. Quanto à recuperação, implica em aplicar técnicas no local alterado, de modo que as condições ambientais acabem se situando próximas às condições anteriores à intervenção.

SANCHEZ (1995) defende o envolvimento da comunidade na fase de operação, planejamento e desativação da lavra. Hoje é necessário conceber o empreendimento desde o seu nascimento até o seu fechamento. Há um entendimento mais recente de que, recuperar uma área significa encontrar um uso produtivo, que pode ser o mesmo uso inicial ou não.

É importante salientar que os impactos podem ser controlados por meio da adoção de medidas preventivas e corretivas. O primeiro caso reveste-se da maior importância, tendo em vista que a prevenção atenua a intensidade de determinados impactos inevitáveis na mineração e, economicamente, representa custos menores em relação às medidas de correção.

\subsection{Operações Unitárias Características da Explotação Mineral}

Segundo ALMEIDA (2003) todo e qualquer procedimento operacional em mineração tem por finalidade a liberação, o enriquecimento ou concentração, o transporte e outras técnicas requeridas na adequação do minério. Simultaneamente, há necessidade de manusear, movimentar e dispor os materiais que não possuem valor de mercado, conhecidos como estéreis (materiais normalmente localizados em camadas que recobrem ou ladeiam o minério) e rejeitos (resíduos gerados durante o processo de beneficiamento).

As condicionantes fundamentais das operações são a economicidade, os impactos ambientais e a qualidade requerida para os produtos minerais.

O empreendimento mineiro, como qualquer empreendimento industrial, tem como objetivo obter lucro com a atividade, fato que impõe limites aos custos operacionais envolvidos. O cuidado com o meio ambiente, seja na redução dos impactos ambientais ou na reabilitação das área atingidas, constitui em quesito imprescindível na ótica de uma mineração bem conduzida. Já os aspectos de qualidade dos produtos estão vinculados às exigências do mercado consumidor, pois condicionam a produção.

Uma diferenciação geral das operações unitárias está relacionada às suas finalidades. Se elas contribuem diretamente na produtividade, são consideradas 
operações unitárias de produção. Já os procedimentos operacionais que apenas dão suporte ao ciclo produtivo são entendidos como operações auxiliares, tendo a função de garantir as condições de segurança, a eficiência das operações unitárias, as vias de acesso para o tráfego das máquinas, o transporte e disposição dos materiais estéreis e rejeitos, a estabilidade dos taludes, a drenagem das águas superficiais, os cuidados gerais ou específicos com o meio ambiente, entre outros. Ambas são conduzidas de maneira integrada, dentro de uma sequência lógica de andamento para otimizar o chamado CBP (Ciclo Básico de Produção), tanto na lavra quanto no tratamento do minério.

\subsection{Agregados para Construção Civil}

Segundo o ANUÁRIO MINERAL BRASILEIRO, 2005, agregados são materiais granulares, sem forma e volume definidos, de dimensões e propriedades para uso em obras de Engenharia Civil. Consideram-se agregados as pedras britadas, o cascalho e as areias naturais ou obtidas por britagem de rocha, além dos substitutivos, como os obtidos de resíduos inertes reciclados, as escórias de aciaria e os agregados industriais, entre outros.

Os agregados são classificados levando-se em conta a origem, a densidade e o tamanho dos fragmentos.

Quanto à origem, são denominados naturais aqueles extraídos diretamente na forma de fragmentos, como areias de rios e pedregulhos e, industriais os que passam por processos de fragmentação, como pedra e areia britadas. Nesta definição observa-se que o termo "industrial" é empregado quanto ao modo de obtenção e não com relação ao material em si. Há autores, entretanto, que classificam estes agregados também como naturais, reservando o termo "artificiais" para os que provêm de um processo industrial, tais como escória britada, argila expandida, entre outros.

Quanto à densidade tem-se: agregados leves (pedra-pomes, vermiculita, argila expandida e outros); agregados pesados (barita, magnetita, limonita e outros) e agregados normais (areias, pedregulhos e pedras britadas ou britas).

Segundo a NBR 7211/2009 (Agregados para concreto - Especificações), quanto ao tamanho dos fragmentos, tem-se:

Agregado graúdo: dimensão mínima superior a 4,8 mm; e 
Agregado miúdo: dimensão máxima igual ou inferior a 4,8mm.

Esta classificação é a mais importante para fins de utilização prática, mas leva em consideração apenas o tamanho dos agregados, ficando a sua natureza e outras propriedades para serem caracterizadas separadamente.

\subsection{Classificação de Areia e Cascalho para Construção Civil}

A areia para construção civil pode ser definida como uma matéria-prima mineral granular, inconsolidada, constituída por grãos predominantemente quartzosos, com ampla faixa de dimensões de partículas entre $50 \mu \mathrm{m}$ e $5 \mathrm{~mm}$. Além do quartzo, outros minerais também podem estar presentes na composição das areias, em quantidades variáveis, a depender da natureza geológica do depósito, como feldspato, mica, minerais "pesados", óxidos e hidróxidos de ferro.

Comercialmente, as areias para construção civil recebem designações segundo o grau de beneficiamento a que são submetidas:

areia bruta - não beneficiada;

areia lavada - lavagem sobre peneira para retirada de partículas finas e outros materiais indesejáveis; e

areia graduada - areia que obedece a uma distribuição granulométrica previamente estabelecida.

De acordo com a granulometria, indicada pela NBR NM 248/03 (Agregados - Determinação da composição granulométrica) os tipos de areia mais comuns encontrados no mercado são:

areia grossa $(2,0 \mathrm{~mm}-4,8 \mathrm{~mm})$;

areia média $(0,42 \mathrm{~mm}-2,0 \mathrm{~mm})$; e

areia fina $(0,05 \mathrm{~mm}-0,42 \mathrm{~mm})$.

A granulometria, determinada segundo a NBR NM 248/03, deve cumprir os limites de somente uma das zonas indicadas na Tabela 1. Podem ser utilizadas areias cuja granulometria não se enquadre em qualquer uma das zonas indicadas na Tabela 1, desde que sejam realizados estudos prévios de dosagem ou então a faixa granulométrica seja de uso consagrado em determinada região. Após definido 
o emprego de uma zona granulométrica para uma obra, a mudança para outra zona somente deve ser aprovada após estudo de dosagem.

Quanto à classificação o agregado é determinado pela NBR 7211/2009 (Agregados para concreto - Especificações), onde o resultado será obtido através da soma das porcentagens retidas acumuladas em massa de um agregado, nas peneiras da série normal, dividida por 100.

O módulo de finura do agregado miúdo, cuja granulometria cumpre com qualquer uma das zonas indicadas na Tabela 1 a seguir, não deve variar em mais de 0,2 para o material de uma mesma origem.

Tabela 1 - Limites da distribuição granulométrica do agregado miúdo.

\begin{tabular}{ccccc}
\hline & \multicolumn{3}{c}{ Porcentagem, em massa, retida acumulada } \\
\cline { 2 - 5 } Peneira com abertura de malha & \multicolumn{2}{c}{ Limites inferiores } & \multicolumn{2}{c}{ Limites superiores } \\
\cline { 2 - 5 } (ABNT NBR NM ISO 3310-1) & Zona & Zona & Zona & Zona \\
& utilizável & ótima & ótima & utilizável \\
$9,5 \mathrm{~mm}$ & 0 & 0 & 0 & 0 \\
$6,3 \mathrm{~mm}$ & 0 & 0 & 0 & 7 \\
$4,75 \mathrm{~mm}$ & 0 & 0 & 5 & 10 \\
$2,36 \mathrm{~mm}$ & 0 & 10 & 20 & 25 \\
$1,18 \mathrm{~mm}$ & 5 & 20 & 30 & 50 \\
$600 \mu \mathrm{m}$ & 15 & 35 & 55 & 70 \\
$300 \mu \mathrm{m}$ & 50 & 65 & 85 & 95 \\
$150 \mu \mathrm{m}$ & 85 & 90 & 95 & 100 \\
\hline
\end{tabular}

\section{NOTAS}

10 módulo de finura da zona ótima varia de 2,20 a 2,90.

20 módulo de finura da zona utilizável inferior varia de 1,55 a 2,20.

3 O módulo de finura da zona utilizável superior varia de 2,90 a 3,50.

$\mathrm{Na}$ construção civil, a areia é empregada como agregado para concreto, argamassas, blocos e pavimentação. A sua granulação e forma tem papel importante na redução do consumo de cimento, na preparação de argamassas ou de concreto, o que implica em redução de custos do concreto.

Apesar de haver um rígido limite das especificações químicas e mineralógicas, a aplicação da areia na construção civil nem sempre observa as 
restrições práticas quanto a materiais deletérios (matéria orgânica, materiais friáveis, sais solúveis, materiais pulverulentos), que podem interferir na qualidade do concreto e das argamassas.

Outro agregado natural também empregado na construção civil, o cascalho, é constituído por fragmentos minerais graúdos, empregados normalmente em lastros de estradas vicinais e ainda em concretos. Pode ser de dois tipos: cascalho arenoso com granulometria superior a 2,0 $\mathrm{mm}$ e inferior a 25,0 $\mathrm{mm}$, geralmente obtido como um subproduto da extração de areias e o cascalho rochoso desagregado, resultante da alteração de rochas como granito, gnaisse, basalto, entre outras.

\subsection{Reações Álcali-Agregado}

A norma NBR 7211/2009 (Agregados para concreto - Especificação) limita o valor máximo do teor de álcalis total (não só do cimento, mas também dos outros componentes do concreto). Esta Norma especifica os requisitos exigíveis para recepção e produção dos agregados miúdos e graúdos destinados à produção de concretos de cimento Portland.

A reação álcali-agregado (RAA) é um processo químico onde alguns constituintes mineralógicos dos agregados, em geral graúdos, reagem com hidróxidos alcalinos (provenientes do cimento, água de amassamento, agregados, pozolanas, agentes externos, entre outros) que estão dissolvidos na solução dos poros do concreto. Como produto da reação forma-se um gel higroscópico expansivo. A manifestação da reação álcali-agregado pode se dar de várias formas, desde expansões, movimentações diferenciais nas estruturas e fissurações até "pipocamentos", exsudação do gel e redução das resistências à tração e compressão (ISAIA, 2005).

Atualmente são descritos três tipos deletérios da reação:

reação álcali-sílica - envolve a presença de sílica amorfa ou certos tipos de vidros naturais (vulcânicos) e artificiais;

reação álcali-silicato - é da mesma natureza da reação álcali-sílica porém, o processo ocorre mais lentamente, envolvendo alguns silicatos presentes nos feldspatos, folhelhos, argilosos, certas rochas sedimentares, (como as grauvacas), metamórficas, (como os quartzitos) e magmáticas (como os 
granitos) fundamentalmente, a presença do quartzo deformado (tensionado) e minerais expansivos; $\mathrm{e}$

reação álcali-carbonato - ocorre entre certos calcários dolomíticos e as soluções alcalinas presentes nos poros do concreto.

A melhor maneira de combate à reação álcalis-agregado (RAA) é evitar sua ocorrência, antes da construção, ou reduzir seus efeitos caso ela tenha se manifestado com a obra pronta.

A reação álcali-agregado torna-se uma preocupação crescente em obras de engenharia, uma vez que pode comprometer o desempenho e durabilidade de estruturas de concreto. Como resultado da reação é a formação de produtos que na presença de umidade são capazes de expandir, gerando fissurações, deslocamentos e podem levar a um comprometimento de estruturas.

\subsubsection{Ensaios Propostos para Prever e Diagnosticar as Reações Álcali- Agregado e seus Efeitos}

Efetuar as análises e ensaios recomendados dos agregados e do conjunto agregado-aglomerante. Caso haja potencialidade de ocorrência da reação usar neutralizadores da mesma no concreto, tais como materiais pozolânicos, sílica ativa, escória granulada moída de alto forno, em proporções previamente estudadas, ou utilizar cimentos pozolânicos ou cimentos de escória de alto-forno contendo materiais pozolânicos ou escória em quantidades adequadas.

Caso a estrutura esteja sofrendo os efeitos da RAA há uma série de procedimentos descritos na literatura técnica especializada que podem auxiliar a diminuir as influências deletérias da reação.

A expansão, deletéria, ocorre quando o gel, formado pela reação absorve água e se expande. As características deste gel dependem de sua composição química e da presença de água. Os principais fatores que influenciam sua formação são:

dimensão do agregado e a presença de certos minerais com silica ou silicatos reativos;

disponibilidade de álcalis do cimento ou de outras fontes internas ou externas; 
presença de umidade; e

temperatura.

\subsection{Formas de Ocorrência dos Depósitos de Areias Naturais}

Os depósitos de areia são resultado da concentração de grãos de quartzo pelo seu transporte e deposição por agentes naturais de intemperismo, a partir de rochas preexistentes, gerando acumulações com maior ou menor concentração do minério e outros minerais de média a elevada dureza e implicando em diferença de dificuldades nas técnicas de extração e recuperação ambiental.

A mineração de areia pode estar relacionada a cinco ambientes geológicos distintos:

$>$ leitos de rios (atuais);

$>$ planícies e terraços aluviais de fundos de vales (pretéritos);

$>$ planícies costeiras;

$>$ coberturas de morros constituídas por formações sedimentares arenosas mais antigas; e

coberturas de morros com mantos de alteração de rochas cristalinas quartzosas.

A Figura 3 a seguir ilustra tais ambientes. 


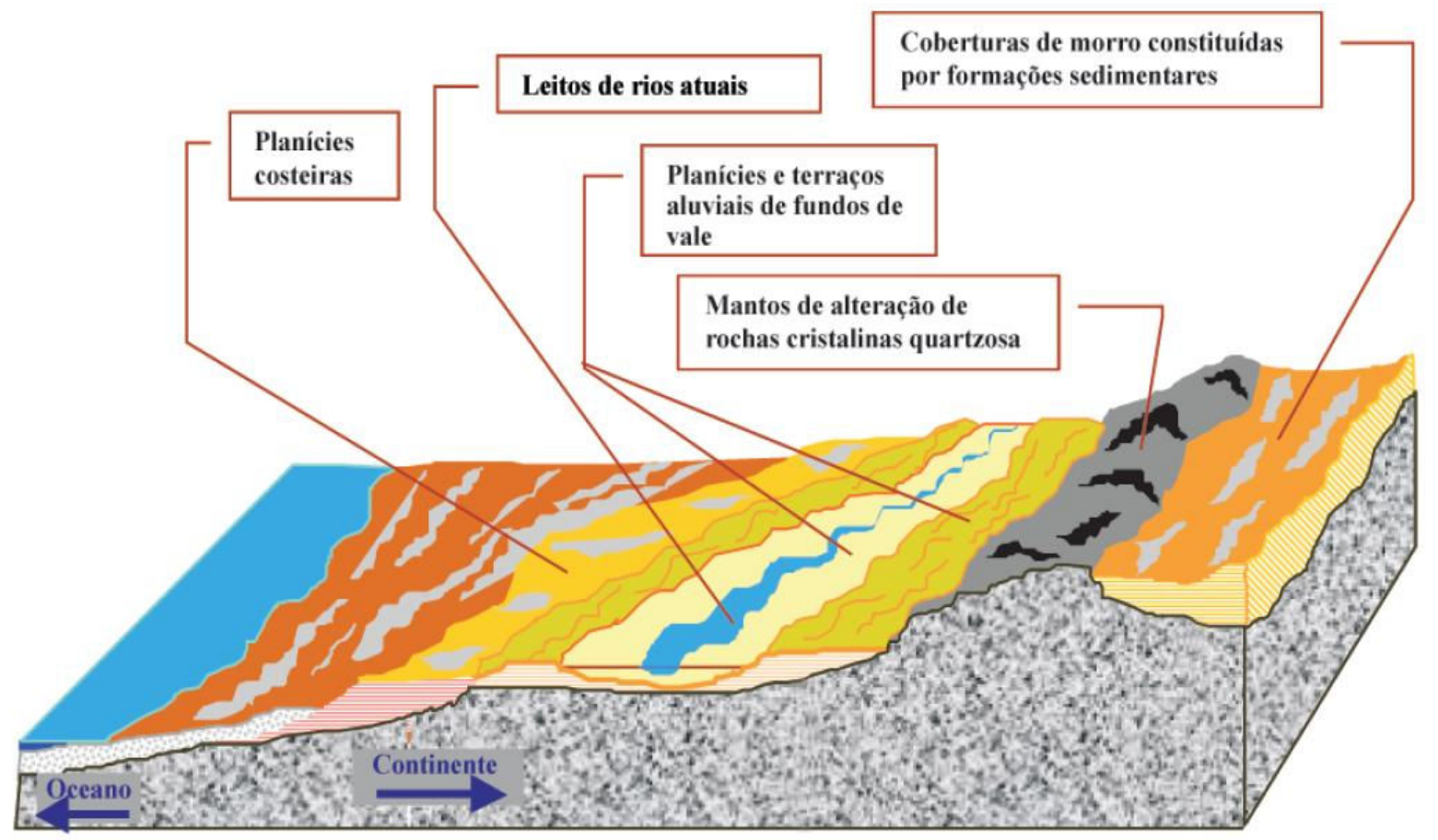

Figura 3 - Ambientes geológicos propícios à extração de areia.

Fonte: ALMEIDA (2003).

\subsection{Quantificação e Qualificação dos Depósitos Naturais}

Os locais de acumulação de areia, em geral, apresentam uma relativa facilidade para elaboração de avaliações quantitativas e qualitativas quando comparadas a outros bens minerais. A geometria tabular ou lenticular simples, aliada à baixa consistência do material, permite sondagens menos onerosas. No caso da amostragem de sedimentos que estiverem sob água, torna-se necessário o revestimento dos furos e o uso de amostradores fechados ou com válvulas para evitar o escoamento e perda das amostras.

A malha de sondagem deve ser dimensionada de forma a cobrir toda a extensão do depósito que se pretende definir, sendo que, à medida que ocorrem variações significativas de espessura e qualidade do material arenoso, deve-se diminuir o espaçamento das perfurações, adensando a malha, para permitir cálculos confiáveis de reserva.

Para a qualificação da areia com a finalidade de aplicação na Construção Civil, são indicadas as seguintes análises laboratoriais:

$>$ análise mineralógica (identificação dos principais minerais constituintes e eventuais deletérios); 
análise granulométrica (caracterização do tamanho dos grãos e indicação de intervalos granulométricos para aplicação); e

análise química para identificação de sais deletérios (principalmente cloretos e sulfatos) e de partículas orgânicas.

Como resultado, os trabalhos de pesquisa mineral devem mostrar a composição e a distribuição espacial do corpo de minério e as variações de espessura, granulometria e distribuição de teores. Estes parâmetros são importantes para se planejar o aproveitamento otimizado da jazida.

O material amostrado deve ser submetido a análises e ensaios que permitam prever o seu comportamento em argamassas ou concretos, principalmente no que se refere a minerais deletérios e contaminantes pulverulentos ou orgânicos.

\subsection{Extração de Areia em Leitos Submersos}

A mineração de areia é conduzida, usualmente, por meio de dois tipos de operações de lavra: desmonte hidráulico ou dragagem hidráulica em leitos submersos. Ambos são baseados na ação da água, diferenciados pela localização do minério que se deseja extrair, sendo que o desmonte hidráulico é utilizado em encostas de morros através do jateamento dos mesmos e a dragagem hidráulica nos leitos fluviais. A água é utilizada tanto para desagregação do minério, como para seu transporte na forma de suspensão ("polpa") e na classificação, separação granulométrica dos produtos. Embora os princípios técnicos de condução das lavras mantenham-se uniformes, existe uma grande variedade de procedimentos práticos, equipamentos e insumos utilizados, cuja escolha depende, basicamente, das condições da jazida, da escala de produção pretendida e dos tipos de produtos a serem comercializados.

\subsubsection{Dragagem Hidráulica em Leitos Submersos}

O termo dragagem é empregado de maneira ampla para qualquer tipo de mineração ou obra em que o material é retirado sob um leito d'água por escavação mecânica ou utilizando-se diversos tipos de máquinas e sistemas que agem por 
força hidráulica de sucção, com ótimo desempenho para retirada das camadas dos sedimentos arenosos no fundo dos rios, lagos e represas.

A lavra de areia por dragagem hidráulica é caracterizada por um sistema de bombeamento que promove a sucção da polpa formada na superfície de ataque do leito submerso. A sua estruturação conta, basicamente, com duas sequências de operação: montagem do sistema de bombeamento sobre uma barcaça móvel, autopropulsora ou movida com o auxílio de barco rebocador e instalação de sistema de bombeamento sobre barcaça com ancoragem fixa, para o qual o minério é transferido por tubulação sustentada sobre flutuadores (geralmente são usados tambores vazios e fechados).

A mobilidade de uma draga permite trabalhar em áreas diferentes, particularmente nos casos em que o depósito explotado apresenta distribuição extensa ao longo de um rio ou represa. O ponto de sucção no fundo da água é atingido por tubulação, através da qual a polpa é transportada. Um valor de referência é uma concentração útil da polpa contendo $20 \%$ de sólidos em massa, para um desnível em profundidade de $10 \mathrm{~m}$, com uso de tubulações com $20 \mathrm{~cm}$ de diâmetro. Estes parâmetros variam conforme a potência das bombas e os diâmetros dos tubos utilizados.

Em casos mais simples e corriqueiros, as minerações de areia realizam apenas um peneiramento grosseiro para separação da fração cascalho e contam com algum dispositivo de decantação, como uma caixa de lavagem, onde ocorre a separação entre o material mais fino, constituído pela fração argilosa, transportado com o excedente de água, e a areia média ou grossa que se deposita no fundo da caixa, sendo esta transferida para pilhas de estocagem e drenagem ao ar livre ou silos de armazenamento e, posteriormente, carregada diretamente em caminhões basculantes convencionais.

Quanto à lama contendo rejeitos finos, a boa técnica recomenda que seja transferida para tanques de alvenaria ou ferro, construídos em cavidades impermeabilizadas no solo, ou efetuada a disposição em bacias definitivas de decantação. Depois de determinado tempo, ocorre o clareamento da água, que eventualmente poderá ser simplesmente reorientada para o rio. Se o local utilizado para decantação for pequeno e não projetado como definitivo, para disposição destes rejeitos (como é o caso dos tanques ou de pequenas cavidades em 
superfície), faz-se necessária a retirada periódica do material depositado por meio de escavação mecânica e a sua disposição final em local apropriado.

A Figura 4 apresenta um esquema geral de lavra submersa em leito de rio, com as respectivas operações envolvidas. A Figura 5 corresponde a um modelo de ciclo básico de produção desta modalidade para minerações de areia.

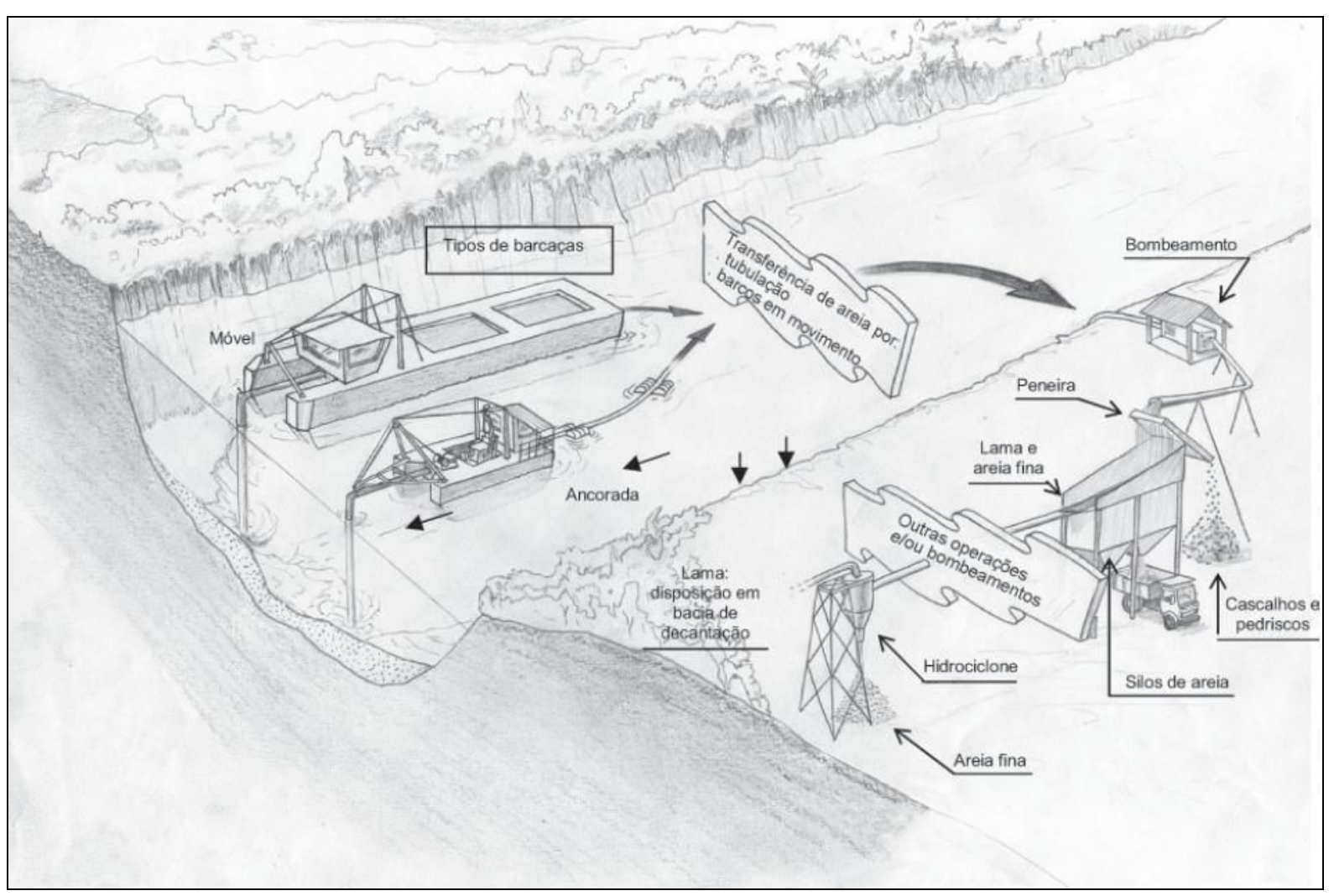

Figura 4 - Mineração de areia: lavra por dragagem em leito de rio. Fonte: ALMEIDA (2003). 


\section{Modelo de Ciclo Básico de Produçāo em Mineraçōes de Areia}

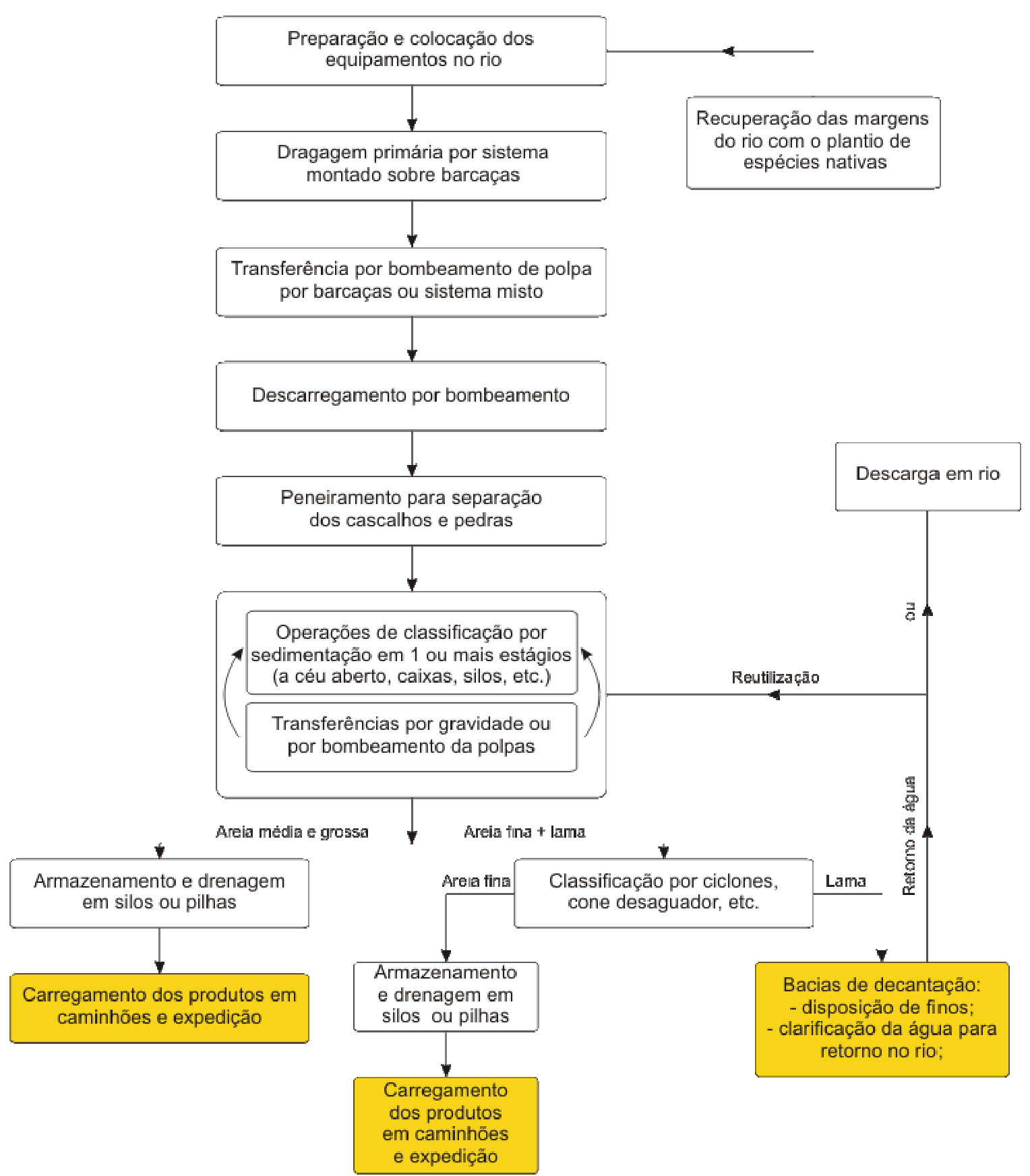

Figura 5 - Mineração de areia: fluxo de operações por dragagem hidráulica em leito de rio. Fonte: ALMEIDA (2003) - modificado. 


\subsubsection{Beneficiamento de Areia}

O beneficiamento da areia para construção civil é um processo executado concomitantemente à lavra e em geral é constituído do peneiramento, classificação e desaguamento.

O termo areia industrial é aqui definido como "... material de granulometria variada, composto essencialmente de sílica e que passou por um processo de beneficiamento..." (FERREIRA, DAITX, 2000).

Entre as diversas etapas de produção de areias, a do beneficiamento é, provavelmente, a mais importante. Numa visão geral, qualquer corpo arenoso pode ser transformado em areia industrial, cujas características estarão implicitamente ligadas às do próprio depósito original, mas o que determinará o seu aproveitamento será, fundamentalmente, a economicidade dos produtos a serem obtidos após o seu beneficiamento, que variam conforme a localização (próximo ou distante de centros consumidores).

Excetuadas questões ligadas ao posicionamento geográfico do mercado consumidor - e, consequentemente, sua relação com o mercado produtor -, a própria visão da prospecção de um depósito arenoso para fins de produção de areia industrial está diretamente subordinada à visão do seu futuro beneficiamento e baseia-se em parâmetros indicadores da ocorrência de um "pré-beneficiamento natural". Entre estes parâmetros destacam-se: corpos arenosos pré-enriquecidos por processos geológicos (depósitos eólicos, fluviais, com zonas "lixiviadas"), distribuição granulométrica que permita a obtenção de diversas frações, grãos com características intrínsecas adequadas (resistência, arredondamento), baixo teor em impurezas ou das frações sem aproveitamento econômico (rejeito), cor do material após lavagem, friabilidade do material, dimensionamento e exposição em superfície, entre outros.

Diversos desses condicionantes presentes nas jazidas, em intensidades diferentes, juntamente com fatores inerentes ao mercado consumidor suprido pelas empresas produtoras, influenciam diretamente os processos de beneficiamento empregados na produção dos diversos tipos de areias naturais.

$O$ beneficiamento do material arenoso visa à retirada de impurezas e de frações sem utilização econômica e a classificação das areias em várias faixas granulométricas adequadas às suas diversas aplicações industriais; representa, em 
síntese, um processo de seleção granulométrica e mineralógica. O principal material a ser separado corresponde à fração silto-argilosa, indesejável em misturas cimentícias e que pode representar até $20 \%$ em massa do minério e ser descartada em lagoas de decantação, por em geral não possuir ainda um aproveitamento econômico viável, representando um dos principais problemas ambientais em todas as minerações de areia. (FERREIRA,1995). Estudos mais recentes pesquisam o aproveitamento dessas frações finas em outras indústrias, porém isto dependerá muito de localização, devido ao baixo valor do material e dos produtos finais.

\subsubsection{Oferta de Areia}

Segundo o Sumário Mineral (SERNA et. al., 2008) os agregados naturais, como as areias de rio, são, em geral, abundantes no Brasil e no mundo. No Brasil, os grandes centros consumidores, representados pelas regiões metropolitanas, estão, geralmente, localizados em áreas geologicamente favoráveis com reservas de boa qualidade. Já a cidade de São Paulo, principal consumidor de areia do Brasil, não dispõe hoje de reservas comerciais próximas e depende de jazidas com distâncias de até $150 \mathrm{~km}$. As rochas utilizadas para produção de brita e que hoje no Brasil dão origem as areias de brita são, fundamentalmente, granitos e gnaisses, seguidos por calcários, dolomitos, basaltos e diabásios, normalmente utilizados em regiões em que os primeiros não são abundantes. Os principais locais de produção de areia são várzeas e leitos de rios, depósitos lacustres e mantos de decomposição de rochas. No Brasil, a utilização de depósitos de areia e cascalhos marinhos está restrita ao controle da erosão e reconstrução praial, muito embora estes recursos já sejam amplamente utilizados como agregados para construção em países da Europa e Ásia.

Os agregados como já citados são os materiais de construção mais utilizados no mundo. Quando se reporta o estado de São Paulo e a Região Metropolitana de São Paulo, para fim de comparação, o consumo per capita avança para 3,5 t/hab.ano e 4,2 t/hab.ano, respectivamente (SERNA et. al., 2008).

A mineração de agregados para a construção civil gera grandes volumes de produção, apresenta beneficiamento simples, baixo preço unitário e necessita ser realizada no entorno do local de consumo, geralmente em áreas urbanas, devido à alta participação do transporte no custo final. O setor de agregados é o segmento da 
indústria mineral que comporta o maior número de empresas e trabalhadores e o único a existir em todos os estados brasileiros.

Atualmente o setor mineral discute o problema da disponibilidade destes recursos, principalmente aqueles localizados dentro ou no entorno dos aglomerados urbanos. A possibilidade de explotação destes bens minerais vem declinando em virtude do inadequado planejamento urbano e territorial, de problemas de sustentabilidade ambiental, de zoneamentos restritivos e de usos competitivos do solo, tornando preocupantes as perspectivas de garantia de suprimento futuro. As reservas de areia e brita no Brasil são estimadas em 2,7 bilhões de toneladas e 12 bilhões de toneladas, respectivamente. Tais números foram obtidos pelo cálculo das densidades de areia e rochas britadas: areia equivale a 1,64 t/m e brita equivale a $1,80 \mathrm{t} / \mathrm{m}^{3}$, de acordo com o Anuário Mineral Brasileiro (2008). Embora em quantidade considerável, a distância dos centros consumidores pode tornar inviável seu aproveitamento.

Tabela 2 - Faturamento da Produção Nacional de Areia

\begin{tabular}{c|c|c|c|c|c|c|c}
\hline \multicolumn{2}{c|}{2004} & \multicolumn{2}{c|}{2005} & \multicolumn{2}{c|}{2006} & \multicolumn{2}{c}{2007} \\
\hline $10^{6} \mathrm{t}$ & $10^{6}$ US\$ & $10^{6} \mathrm{t}$ & $10^{6}$ US $\$$ & $10^{6} \mathrm{t}$ & $10^{6}$ US\$ & $10^{6} \mathrm{t}$ & $10^{6}$ US\$ \\
\hline 201 & 832 & 238 & 812 & $255(\mathrm{p})$ & $(\ldots)$ & $279(\mathrm{p})$ & $(\ldots)$ \\
\hline
\end{tabular}

Fonte: SERNA et al. Anuário Mineral Brasileiro DNPM (2008).

Notas: (p) preliminar; (...) não disponível.

\subsection{Panorama sobre a Demanda de Areia}

Uma pesquisa realizada pela ANAMACO ${ }^{2}$ - Associação Nacional dos Comerciantes de Material de Construção em parceria com a Latin Panel em 8.200 lares brasileiros analisou o comportamento do consumidor de material de construção. Segundo o estudo, o consumidor brasileiro teve um gasto médio de R\$ 1.344,20 com material de construção em 2007 , e que $77 \%$ das residências do país precisam de algum tipo de reforma ou construção. O cômodo mais reformado foi o dormitório. Para as classes $A B$, as reformas ocorreram em sua maioria nas áreas externas da casa, enquanto que nas classes DE os destaques foram a cozinha e o banheiro. $O$ estudo aponta ainda que 1 a cada 3 lares brasileiros pretende reformar

\footnotetext{
${ }^{2}$ ANAMACO. Comunicação na 17a. Feira Internacional da Indústria da Construção, 2008.
} 
ou construir em um futuro próximo segundo divulgado na $17^{\text {a }}$ Feira Internacional da Indústria da Construção.

Decorrido o ano 2008, o que se percebeu é que as empresas de mineração de areia para construção civil do estado de São Paulo têm investido na melhoria de sua infra-estrutura para acompanhar o desempenho e crescimento do setor.

Segundo o presidente ${ }^{3}$ do SINDUSCON-SP (Sindicato da Indústria da Construção Civil do Estado de São Paulo), o setor da construção civil estimou um crescimento em torno de $10 \%$ para o ano 2008.

Dados recentes deste sindicato, sobre a indústria de materiais de construção civil, indicam que esta perspectiva foi comprovada. $O$ consumo de cimento cresceu $8,4 \%$ no mesmo período. Nesta base de comparação, as vendas de vergalhões subiram $12,2 \%$ e o emprego na construção avançou $7,4 \%$ - com a geração de mais de 200 mil novas vagas no país.

O sindicato ainda ressalta o produtor de areia em Igarapava, norte do estado de São Paulo e fornecedor de areia para a região do Triângulo Mineiro, o sócio diretor da Mineração Vale do Rio Grande Ltda., confirmou um crescimento de 15 a $20 \%$ no primeiro semestre de 2008 , em comparação com o mesmo período do ano anterior. "Sem dúvida o mercado estará muito mais aquecido em relação ao ano passado. Existem ainda algumas obras de grande porte para se iniciarem este ano e as indústrias produtoras de areia, que já estão com o máximo de sua capacidade produtiva, não conseguirão atender esta forte demanda prevista".

Em resumo, segundo este produtor, a região do Triângulo Mineiro está com falta de areia e ressalta "É claro que não podemos esquecer da forte pressão dos custos operacionais impulsionada pela alta do óleo diesel, principal insumo da nossa produção".

Na região noroeste do estado de São Paulo, um empresário, fez um balanço com acréscimo de $30 \%$ no volume das vendas de 2008 e conta as mudanças que foram possíveis fazer em sua empresa Areias Salioni Ltda. "Fizemos investimentos em transportes, adquirindo novos caminhões e planejamos fazer novos investimentos na produção".

No Vale do Ribeira, o presidente da AMAVALES - Associação dos Mineradores de Areia do Vale do Ribeira e Baixada Santista, afirma que as

\footnotetext{
${ }^{3}$ ROBUSTI, J. C. Comunicação pessoal, 2008.
} 
empresas da região investiram na compra de novas carregadeiras e de uma escavadeira hidráulica - equipamentos de maior porte, além da melhoria e modernização das usinas de beneficiamento.

Desta forma, observam-se algumas tendências de aumento da demanda e consequentemente, realização de investimentos para a adequação a um mercado em constante crescimento às suas reais necessidades.

\subsection{Mercado de Areia para o Vale do Paraíba}

O mercado de areia apresentado no Vale do Paraíba é bastante oscilante e depende em grande parte do número de extratoras em operação, o que varia consideravelmente de período para período.

Para uma análise do mercado consumidor devem ser levados em consideração inúmeros fatores, dentre estes:

> consumo e necessidade do produto;

$>$ distância do produtor-consumidor e distribuição; e preço do produto.

Obviamente, nestes itens citados, ainda deve-se considerar as influências da concorrência, do poder aquisitivo, dentre inúmeros outros que também fazem parte desta análise.

Do ponto de vista da distância entre mercado consumidor e o local de produção, o empreendimento mineral deste estudo na área é bastante atrativo, uma vez que este situa-se próximo a centros urbanos de destaque, como Taubaté e São José dos Campos, podendo atender também à região metropolitana de São Paulo.

Segundo OLIVEIRA (2008) com base em dados do Anuário Mineral de 2006, do DNPM, o estado de São Paulo é o $4^{\circ}$ maior produtor mineral do país, produzindo 27 sustâncias minerais, das quais apenas seis respondem por $96 \%$ do valor da produção paulista: pela ordem, areia natural, rochas para brita, calcário, areia industrial, fosfato e caulim. Apenas a areia e rocha para brita respondem por $67 \%$ daquele valor. A produção paulista é de 96 milhões de toneladas anuais de areia e 60 milhões de toneladas anuais de brita. 
O consumo destes materiais em São Paulo como já citado é de 3,5 t/hab.ano, enquanto a média nacional é de 2 t/hab.ano e a dos países desenvolvidos, entre 7 e 10 t/hab.ano.

Até o ano de 2006, o Estado possuía 12 mil títulos minerários registrados no DNPM e havia empregado 15 mil trabalhadores, sendo $80 \%$ deles em 4 operações: rocha para brita, água mineral, areia e calcário.

Os dois casos a seguir ilustram a situação de tal mercado no ano de 2006 (SANTOS; OLIVEIRA, 2008).

\subsubsection{UTG da Petrobrás em Caraguatatuba}

Segundo SANTOS; OLIVEIRA (2008) no Vale do Paraíba, Marcelino Simões, tradicional minerador e proprietário de dois empreendimentos minerários na região confirma o aquecimento do setor. "As obras da Petrobras em São José dos Campos e, principalmente, a obra em Caraguatatuba são os dois fatores importantes neste aquecimento". Conta ainda que a Mineração Trevo Ltda., no município de Jacareí, investiu recentemente na compra de uma pá carregadeira. "Precisamos investir ainda em uma escavadeira e novos caminhões", afirma Simões.

O fluxo de caminhões na Rodovia dos Tamoios (SP-99), principal ligação de São José dos Campos com o Litoral Norte, duplicou no último ano, de acordo com a Polícia Rodoviária Estadual. A polícia acredita que o aumento no tráfego pesado é consequência direta das obras que a Petrobrás realiza em Caraguatatuba para a construção da UTG (Unidade de Tratamento de Gás). Desde o ano passado, a estatal iniciou a implantação do duto de gás do Projeto Mexilhão, localizado a 137 km da costa de Caraguatatuba.

De acordo com o comando do patrulhamento rodoviário, foi verificado principalmente um fluxo mais intenso dos caminhões que transportam areia de construção civil, utilizada na base e terraplanagem das áreas onde será erguida a UTG. De acordo com o DER - Departamento de Estrada de Rodagem, atualmente, os dados obtidos através da balança da rodovia, mostram que passam por dia, cerca de 500 caminhões.

As dificuldades na obtenção das licenças ambientais, entretanto, já atrasaram em quase um ano o cronograma de operações do Campo de Mexilhão, na 
Bacia de Santos, exatamente pelo atraso na implantação da Unidade de Tratamento de Gás, de Caraguatatuba.

A Licença de Instalação, emitida no fim do ano passado, permite apenas as obras de terraplanagem e estaqueamento do terreno. Somente as obras de UTG deverão consumir mais de um milhão e duzentos mil metros cúbicos de areia, necessários para a realização da base da Unidade. Por conta da obra, políticos e entidades de classe têm cobrado a aceleração do projeto de duplicação da Rodovia dos Tamoios.

\subsubsection{Obras do Rodoanel em São Paulo}

De acordo com SANTOS; OLIVEIRA (2008), o Rodoanel é uma obra fundamental para o trânsito caótico da metrópole paulista e foi dimensionado para dar vazão ao transporte de cargas entre a região Centro - Oeste, o Sul da cidade de São Paulo e o Porto de Santos, interligando cinco rodovias às vias Anchieta e Imigrantes.

O Governo do Estado de São Paulo pretende executar cerca de $57 \mathrm{~km}$ do Trecho Sul do Rodoanel, que está devidamente licenciado, até o primeiro semestre de 2010.

Para conseguir cumprir o cronograma da maior obra de infra-estrutura paulista em desenvolvimento, a velocidade de construção da rodovia deverá figurar como um feito histórico, com investimentos previstos da ordem de $\mathrm{R} \$ 2,5$ bilhões.

Este trecho do Rodoanel terá varias faixas de rolamento, em cada sentido, e passará por diversas áreas urbanizadas, além de outras com intensa restrição ambiental. As características apresentadas e a complexidade do empreendimento fizeram com que o processo de licenciamento ambiental durasse cinco anos e a Licença de Instalação apresentasse 347 exigências técnicas.

A contratante da obra, o DERSA - Desenvolvimento Rodoviário S.A., empresa que representa o Governo do Estado de São Paulo no empreendimento, acredita que, com a liberação do Trecho Sul, somado ao Trecho Oeste (já em pleno funcionamento), haverá redução de $30 \%$ a $40 \%$ no volume de veículos de carga nas marginais do Rio Pinheiros e do Rio Tietê, importantes vias de tráfego da cidade de São Paulo. 
Não foram divulgados os volumes de agregados a serem consumidos nesta obra, contudo a expectativa de consumo de concreto gira em torno de $32.000 \mathrm{~m}^{3}$.

\subsection{Zoneamento Ambiental Minerário do Vale do Paraíba}

Um dos principais problemas enfrentados pelos municípios da calha do rio Paraíba do Sul refere-se ao conflito de uso de sua várzea. Conforme mencionado anteriormente, existem três utilizações básicas que disputam espaço na área: o uso urbano, a agropecuária e a mineração, todas elas com maiores ou menores restrições ambientais. O zoneamento minerário, em desenvolvimento na Secretaria de Estado do Meio Ambiente, tem catalisado a discussão recente deste problema na área.

As principais críticas levantadas ao estudo se referem à visão setorial e parcial da questão. Por um lado, critica-se a insuficiência de um zoneamento minerário que trate exclusivamente da areia, havendo outras jazidas na região. Por outro lado, critica-se a elaboração do zoneamento de uma área considerando apenas os interesses da explotação mineral em confronto com a preservação da várzea, excluindo os interesses dos demais agentes envolvidos.

Os municípios, em geral, vêm participando ativamente das discussões em andamento, desenvolvendo propostas próprias com vistas a que sejam incorporadas no zoneamento estadual. Entretanto, o zoneamento minerário existente hoje se estende apenas até Pindamonhangaba. Assim sendo, os municípios de jusante do Rio Paraíba do Sul não estão contando com este fator de catalização das preocupações relativas ao ordenamento da ocupação da várzea e de sua preservação. Verifica-se que em grande parte dos municípios o controle do uso e ocupação do solo está carente de recursos legais, administrativos, humanos e financeiros para fazer frente aos conflitos gerados em torno desta questão e de outras mais que afetam as áreas urbanas da região.

Outro aspecto a ser destacado dentre os problemas urbanos e que mais diretamente afetam os recursos hídricos é a ocorrência de inundações, hoje não mais decorrentes do transbordamento do rio Paraíba do Sul, já controlado, mas de seus afluentes, muitas vezes estrangulados por obras de infra-estrutura subdimensionadas. O caso mais recorrente refere-se às travessias da Dutra e da 
Ferrovia Sul, dimensionadas para picos de cheia calculados para condições de permeabilidade do solo muito superiores às atualmente verificadas na área.

A expansão urbana de Jacareí, São José dos Campos e Aparecida, a leste da Dutra, impermeabilizando grandes extensões do território, provocou o aumento dos picos de cheia, exigindo redimensionamento das obras de travessia da Dutra. Finalmente, talvez o maior problema que aflige as áreas urbanas do Vale do Paraíba é constituído pela contaminação das águas, seja pelos esgotos sanitários, seja pela disposição inadequada de outros resíduos sólidos. Tais aspectos são tratados de forma sistemática nos relatórios específicos, não cabendo aqui fazer maiores comentários além de casos mais críticos, como o do Vidoca em São José dos Campos, o do Turí e do Comprido em Jacareí, ou o caso de Aparecida, onde a tomada d'água da cidade se localiza imediatamente a jusante do seu principal despejo de esgotos. A situação da disposição final dos resíduos sólidos, à exceção de São José dos Campos e de Jacareí, é extremamente grave na região.

Devido ao significativo potencial minerário areeiro do Vale do Paraíba, a região foi a primeira do Brasil sobre a qual se formulou um Zoneamento Ambiental Minerário, compreendendo $o$ trecho entre os municípios de Jacareí e Pindamonhangaba. O documento, concluído em 1999 e regulamentado pela Resolução SMA - Secretaria do Meio Ambiente 28/99, estabeleceu diretrizes para o disciplinamento e o licenciamento da extração de areia na várzea do Paraíba, por se tratar de uma atividade considerada degradadora e modificadora do meio ambiente. As áreas aptas para a mineração foram definidas em função de seu potencial de produção e estimativa de estoque de areia e a atividade foi compatibilizada com os demais usos do solo.

A seguir são apresentadas as figuras que ilustram o zoneamento minerário nos trechos Jacareí e Caçapava (Figuras 6 e 7). 


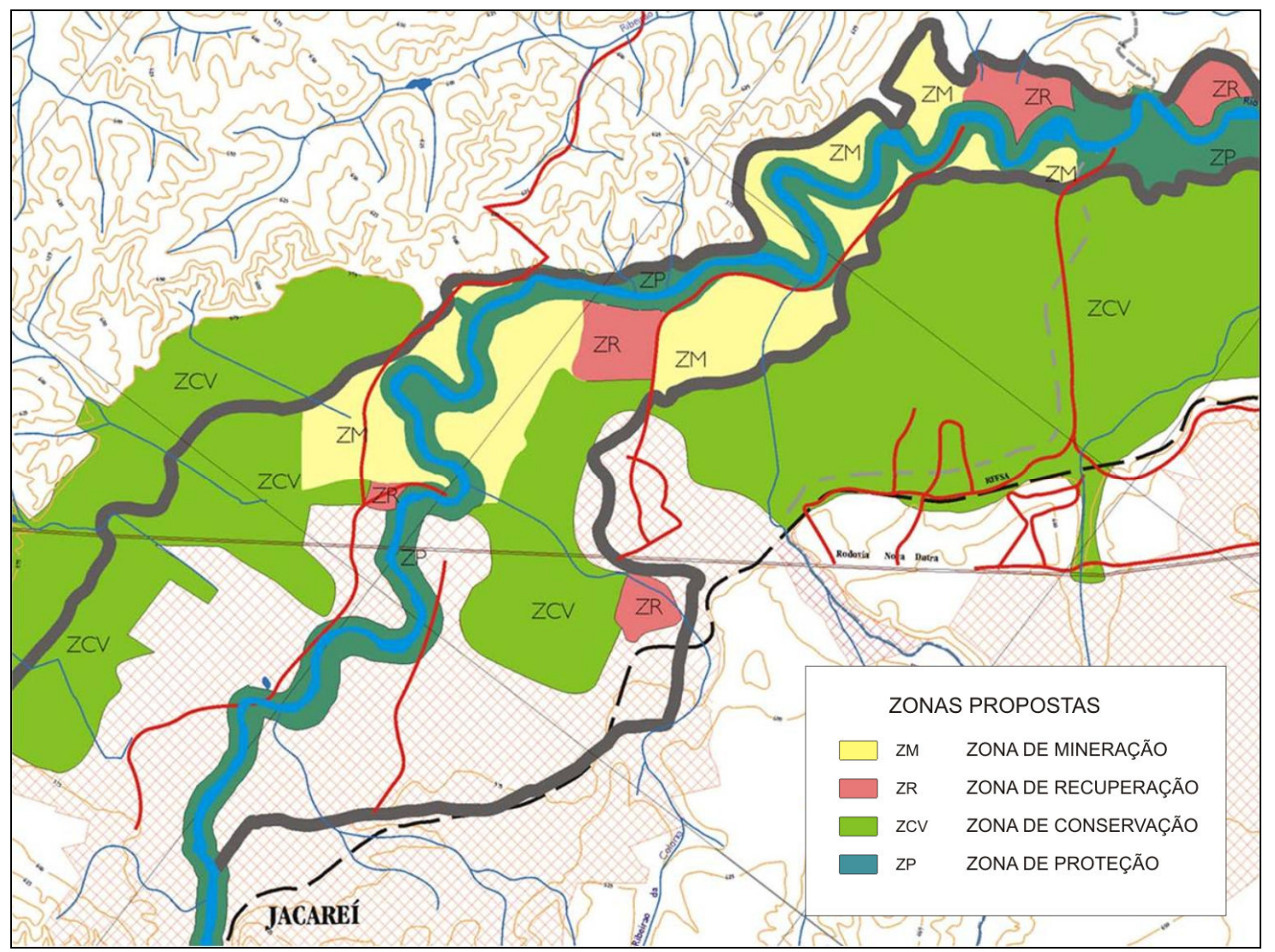

Figura 6 - Zoneamento ambiental para mineração de areia no Rio Paraíba do Sul (Trecho Jacareí). Fonte: Resolução SMA 28 (1999).

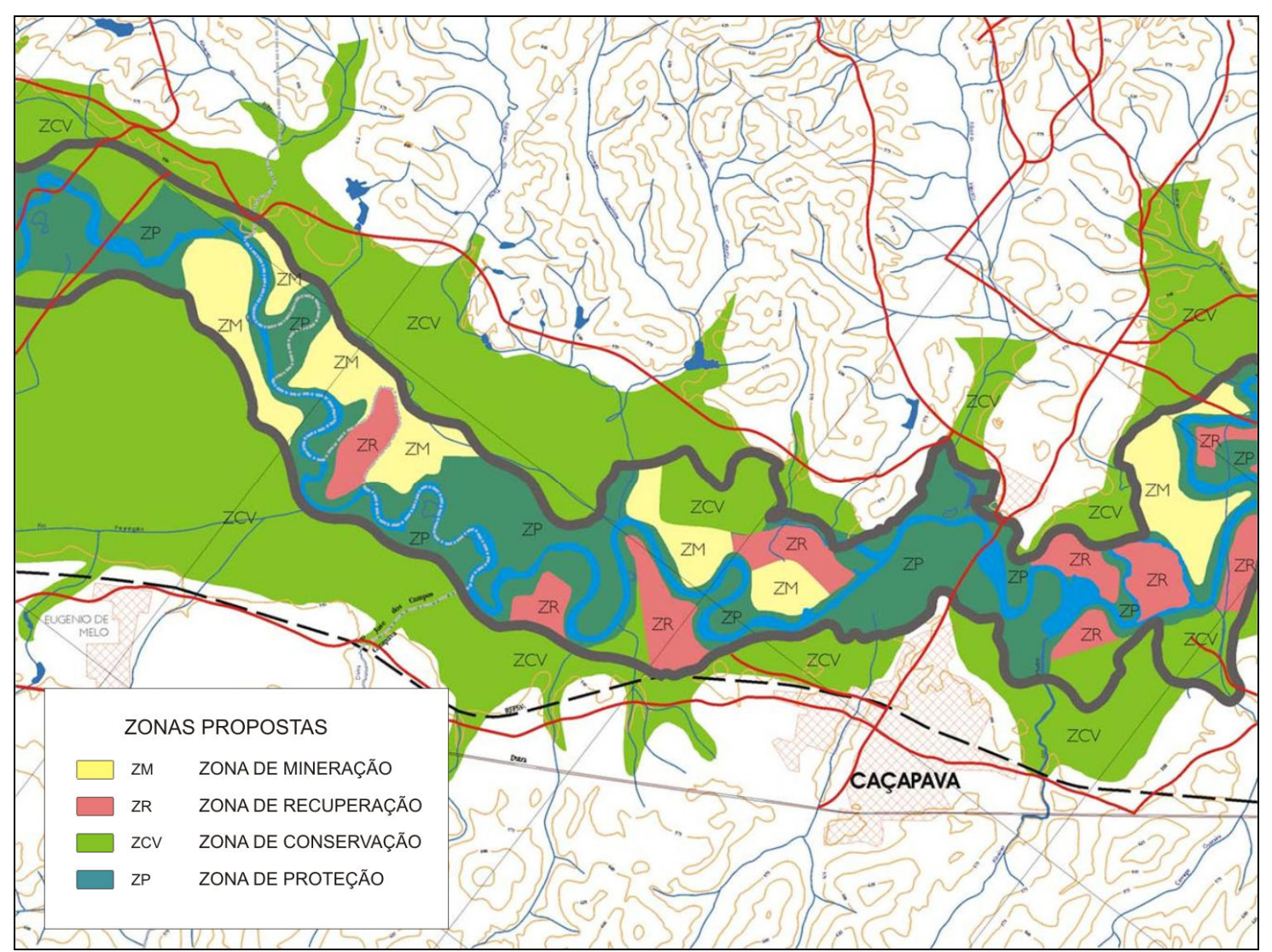

Figura 7 - Zoneamento ambiental para mineração de areia no Rio Paraíba do Sul (Trecho Caçapava). Fonte: Resolução SMA 28 (1999). 
As informações apresentadas no levantamento técnico da DEPRN/CETESB/PAmb (2007) correspondem à avaliação da recuperação ambiental da mineração de areia para subsidiar instrumentos para gestão ambiental na Várzea do Paraíba do Sul, Trecho Jacareí-Pindamonhangaba.

As Figuras 8 e 9 apresentam levantamentos de dados e vistorias realizados pelo núcleo de monitoramento ambiental das atividades minerárias do Vale do Paraíba nos empreendimentos cadastrados no levantamento técnico referente à recuperação ambiental da mineração.

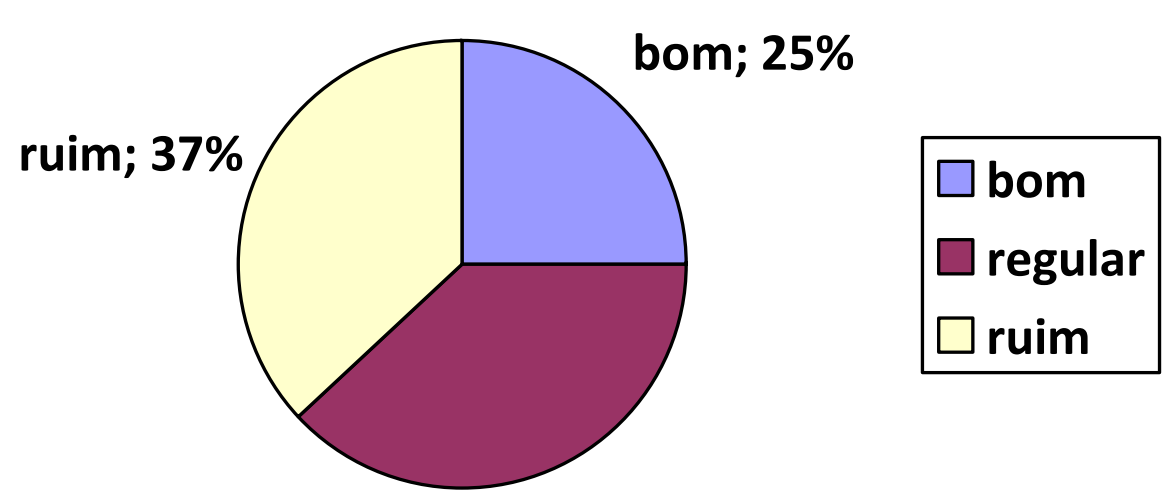

regular; $38 \%$

Figura 8 - Situação de implantação da recuperação em geral no trecho Jacareí à Pindamonhangaba. Fonte: Agências DEPRN/CETESB/PAmb (2007). 


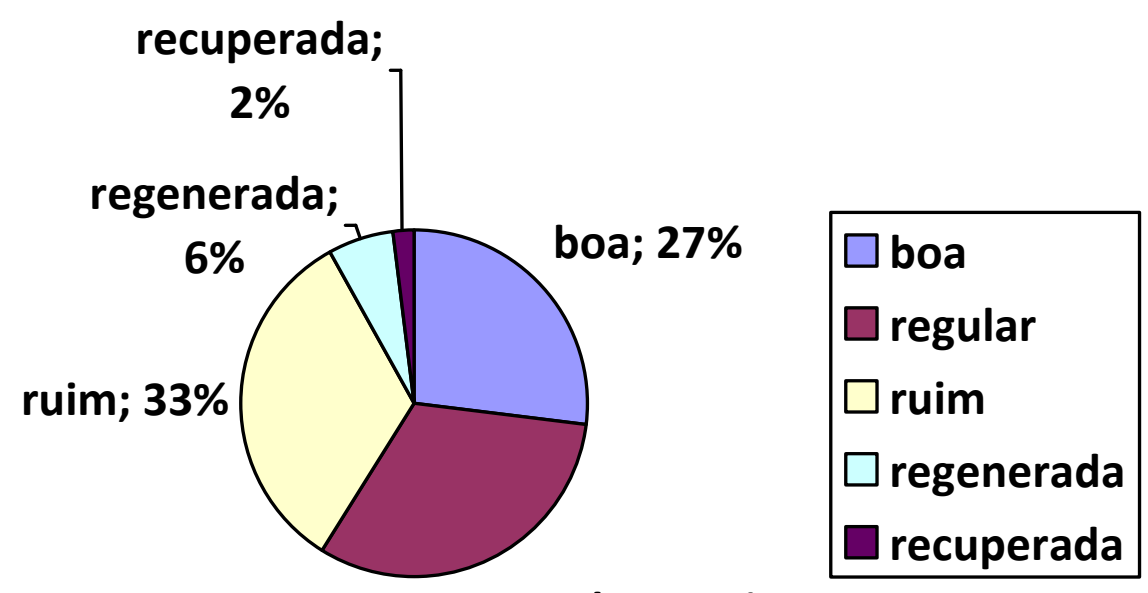

regular; 32\%

Figura 9 - Qualidade de recuperação vegetal no trecho Jacareí à Pindamonhangaba. Fonte: Agências DEPRN/CETESB/PAmb (2007).

A Tabela 3 e Figura 10 apresentam a quantificação de empreendimentos minerários antes e após as resoluções da SMA onde são estabelecidas diretrizes para o licenciamento ambiental.

Tabela 3 - Situação dos portos de areia do Vale do Paraíba

\begin{tabular}{c|c|c|c}
\hline \multirow{2}{*}{ Municípios } & $\begin{array}{c}\text { Antes da } \\
\text { Resolução } \\
\text { SMA 42/96 em } \\
\text { funcionamento }\end{array}$ & $\begin{array}{c}\text { Após Resoluções SMA 42/96 e 28/99 } \\
\text { Em operação até } \\
\text { março 2007 }\end{array}$ & $\begin{array}{c}\text { Paralisados ou } \\
\text { encerrados até } \\
\text { março 2007 }\end{array}$ \\
\hline Jacareí & 21 & 06 & 16 \\
\hline São José dos Campos & 14 & - & 12 \\
\hline Caçapava & 29 & 11 & 25 \\
\hline Taubaté & 22 & 08 & 15 \\
\hline Tremembé & 33 & 16 & 29 \\
\hline Pindamonhangaba & 27 & 09 & 06 \\
\hline Total relacionado & 149 & 50 & 105 \\
\hline
\end{tabular}

Fonte: Agências DEPRN/CETESB/PAmb (2007). 


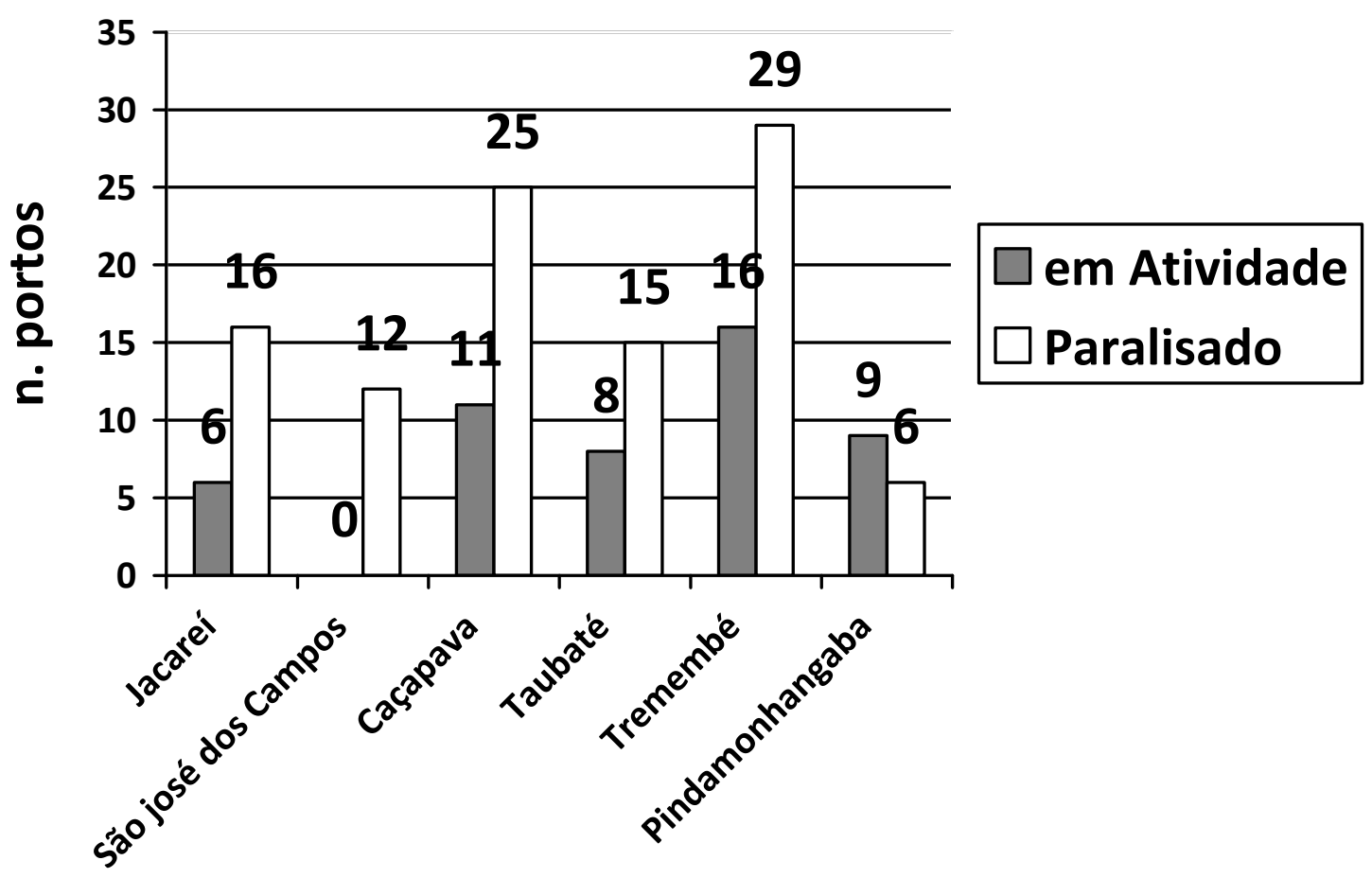

Figura 10 - Atividade de extração de areia.

Fonte: Agências DEPRN/CETESB/PAmb (2007).

\subsection{Premissas Legais e Sociais das Obras de Desassoreamento}

De acordo com a Resolução CONAMA - Conselho Nacional de Meio Ambiente $n^{\circ} 369$ de 28 de março de 2006 que dispõe sobre os casos excepcionais, de utilidade pública, interesse social ou baixo impacto ambiental, que possibilitam a intervenção ou supressão de vegetação em APP - Área de Preservação Permanente, em seu artigo 2, inciso I no item f). Neste estudo compete o caso de utilidade pública, uma vez que o serviço de captação e distribuição de água no município corre risco de paralisação:

Art. $2^{\circ} \mathrm{O}$ órgão ambiental competente somente poderá autorizar a intervenção ou supressão de vegetação em APP, devidamente caracterizada e motivada mediante procedimento administrativo autônomo e prévio, e atendidos os requisitos previstos nesta resolução e noutras normas federais, estaduais e municipais aplicáveis, bem como no Plano Diretor, Zoneamento Ecológico-Econômico e Plano de Manejo das Unidades de Conservação, se existentes, nos seguintes casos:

A...

I - utilidade pública:

a)... 
f) obras públicas para implantação de instalações necessárias à captação e condução de água e de efluentes tratados;

Considerando que a Estação de Tratamento de Águas do município de Paraibuna, vem enfrentando problemas com a sucção de areia e outros detritos, fato este que diminui a capacidade de captação e aumenta o desgaste de equipamentos, a Prefeitura, através do Decreto n. 2416 de 23 de março de 2009, autoriza o desassoreamento do Rio Paraíba do Sul e seus afluentes, nos trechos necessários à melhoria das condições da captação d'água para a Estação de Tratamento de Águas do Município de Paraibuna.

No Decreto n. 2285 de 24 de março de 2009, declara de utilidade pública as obras de desassoreamento do Rio Paraíba do Sul e de seus afluentes, nos trechos necessários à melhoria das condições de captação d'água.

Ainda no mesmo Decreto tais obras poderão ser realizadas pelo poder executivo diretamente, seus contratados ou autorizados, sendo certo que neste último caso estes deverão comprovadamente deter direitos sobre o trecho em que se realizará o desassoreamento.

Declara ainda que: "no caso dos autorizados, o Município de Paraibuna não se responsabilizará por qualquer intervenção no leito ou nas margens do rio Paraíba do Sul e de seus afluentes, bem como por quaisquer danos, diretos e/ou indiretos, delas provenientes; nem pelas compensações, recuperações ou recomposições ambientais, nem pelas anuências ou autorizações junto ao poder público ou particulares que se fizerem necessárias."

\subsection{Meio Físico - Solo}

Através de trabalhos de pesquisa secundária foi possível o levantamento de dados pertinentes à área de estudo, tais como: bases topográficas, fotografias aéreas e material bibliográfico, contendo informações sobre geologia, relevo e outros dados do interesse, descritos a seguir.

O objetivo do estudo do meio físico é contribuir para diagnosticar os processos dinâmicos do assoreamento e subsidiar possibilidades para outro planejamento minerário. 


\subsubsection{Geomorfologia Regional}

O Vale do Rio Paraíba do Sul está inserido na Província Geomorfológica do Planalto Atlântico, caracterizando as zonas do Planalto de Paraitinga, Planalto da Bocaina, Médio Vale do Paraíba e parte da Serra da Mantiqueira, conforme ALMEIDA (1964).

Em linhas gerais, na região do Vale ocorrem altimetrias que vão desde os 100 m, nas margens do Rio Paraíba do Sul, a 1.250 m, nos topos das cristas. O rio apresenta leito meândrico em seu curso médio-superior (Bacia de Taubaté) e calha retilinizada no seu curso médio-inferior, onde corta a área estrutural entre os alinhamentos serranos (PROJETO RADAMBRASIL, 1983). Os morros desenvolvidos sobre rochas pré-cambrianas e regiões de colinas sedimentares conferem à UGRHI-2 (Unidade de Gerenciamento de Recursos Hídricos da Bacia do Rio Paraíba do Sul) topografia complexa e rugosa, onde o relevo mamelonar típico é chamado de "mar de morros", estando o Vale do Paraíba encaixado entre a Serra da Mantiqueira e o Planalto de Paraitinga.

\subsubsection{Geomorfologia Local}

Segundo ALMEIDA (1964) a região do Vale do Paraíba está localizada no Planalto Atlântico, na Zona do Planalto Paraitinga e na subzona da Morraria do Paraibuna.

O Planalto Atlântico (Província I) caracteriza-se como uma região de terras altas (IPT,1981), situando-se a sudeste/leste do Estado de São Paulo. É constituído por formas de topos convexos, elevada densidade de canais de drenagem e vales profundos (ROSS \& MOROZ, 1997). O Planalto Atlântico é de estrutura complexa e apresenta variações de altitude compreendidas entre 650 e 1250 m. Limita-se a noroeste pela Depressão Periférica e ao sul pela Serra de Paranapiacaba e as escarpas da Serra do Mar; em sua maior parte, o relevo resulta diretamente da erosão fluvial exercida sobre um complexo muito heterogêneo de rochas ígneas e metamórficas. As variações estruturais e diversidades resultantes da história do Planalto Atlântico ocasionaram o aparecimento de inúmeras feições geomórficas (como planaltos bem compartimentados) e grandes estruturas tectônicas, como o Graben por onde corre o Rio Paraíba do Sul. 
O Planalto do Paraitinga (Zona 2), localizado na porção sudeste da UGRHI2, incorpora áreas serranas e áreas de morros, constituindo formas de relevo com alto grau de dissecação e modelado, muitas vezes alongado, principalmente na região serrana onde separam-se as bacias hidrográficas dos rios Paraitinga e Paraibuna. Tal região serrana, de maior resistência aos processos erosivos pela presença de granitóides e que exerce o papel de divisor de águas destes rios, diferencia também o modelado de ambas as bacias hidrográficas: a morraria na bacia do Rio Paraitinga apresenta sistema de mar de morros de formas mais suavizadas e arredondadas, mostrando já não guardar herança estrutural tão forte e possuir menor energia do relevo; já a morraria na bacia do Rio Paraibuna é marcada pelo controle estrutural, evidenciado pela rede de drenagem encaixada (padrão em treliça), além de possuir relevo mais enérgico. Inclusive, esta última fundamenta-se na organização tectônica da área, adaptada aos sistemas de falhas e fraturas existentes (IPT,1981); contudo, mesmo havendo diferença na influência do controle estrutural e no grau de dissecação, ambos os rios apresentam orientação NE-SW, com suas cabeceiras nascendo a altitudes superiores a $1.600 \mathrm{~m}$ (PROJETO RADAMBRASIL, 1983).

O Planalto de Paraitinga é um planalto cristalino de estrutura complexa, maturamente dissecado, com relevo de mar de morros e longas serras longitudinais e na região do rio Paraibuna os morros são menores em área quando comparados com os morros do rio Paraitinga, porém com alturas equivalentes. A drenagem principal (rio Paraibuna) é encaixada, não formando planícies aluvionares e a influência estrutural é marcante, traduzida pelo padrão em treliça da drenagem que é governada por sistemas de juntas NW e pela foliação NE das rochas, constituindo a subzona morraria de Paraibuna. O sistema de relevo nesta subzona é do tipo morros paralelos, exceto nas proximidades de Paraibuna onde o relevo é mar de morros e junto às bordas do planalto, onde ocorrem morrotes baixos.

O relevo de morrotes baixos nivela os cimos da Serra do Mar e é drenado para a bacia do rio Tiête no Planalto Paulistano e também em direção à do rio Paraibuna, no Planalto do Paraitinga, representado por indícios mais claros de uma antiga superfície de erosão que originalmente estendeu-se através destes dois planaltos. 
Os morros paralelos são o relevo mais característico da morraria de Paraitinga; a drenagem mais encaixada e a maior dissecação do relevo não foram suficientes para apagarem os indícios da primitiva superfície de erosão.

O relevo do tipo mar de morros resulta do anterior (morros paralelos), representando uma fase mais avançada da evolução geomorfológica, em que morros já não refletem tão acentuadamente a estrutura e apresentam formas predominantemente mamelonares.

\subsubsection{Geologia Local}

$\mathrm{Na}$ área alvo deste estudo predominam litologias do tipo micaxistos e quartzo micaxistos, cortados no sentido sudoeste-nordeste pela zona de falha de Cubatão, representada pelas rochas cataclásticas típicas de falhas transcorrentes.

A Figura 11 a seguir apresenta a localização da área conforme CPRM Companhia de Pesquisa de Recursos Minerais.

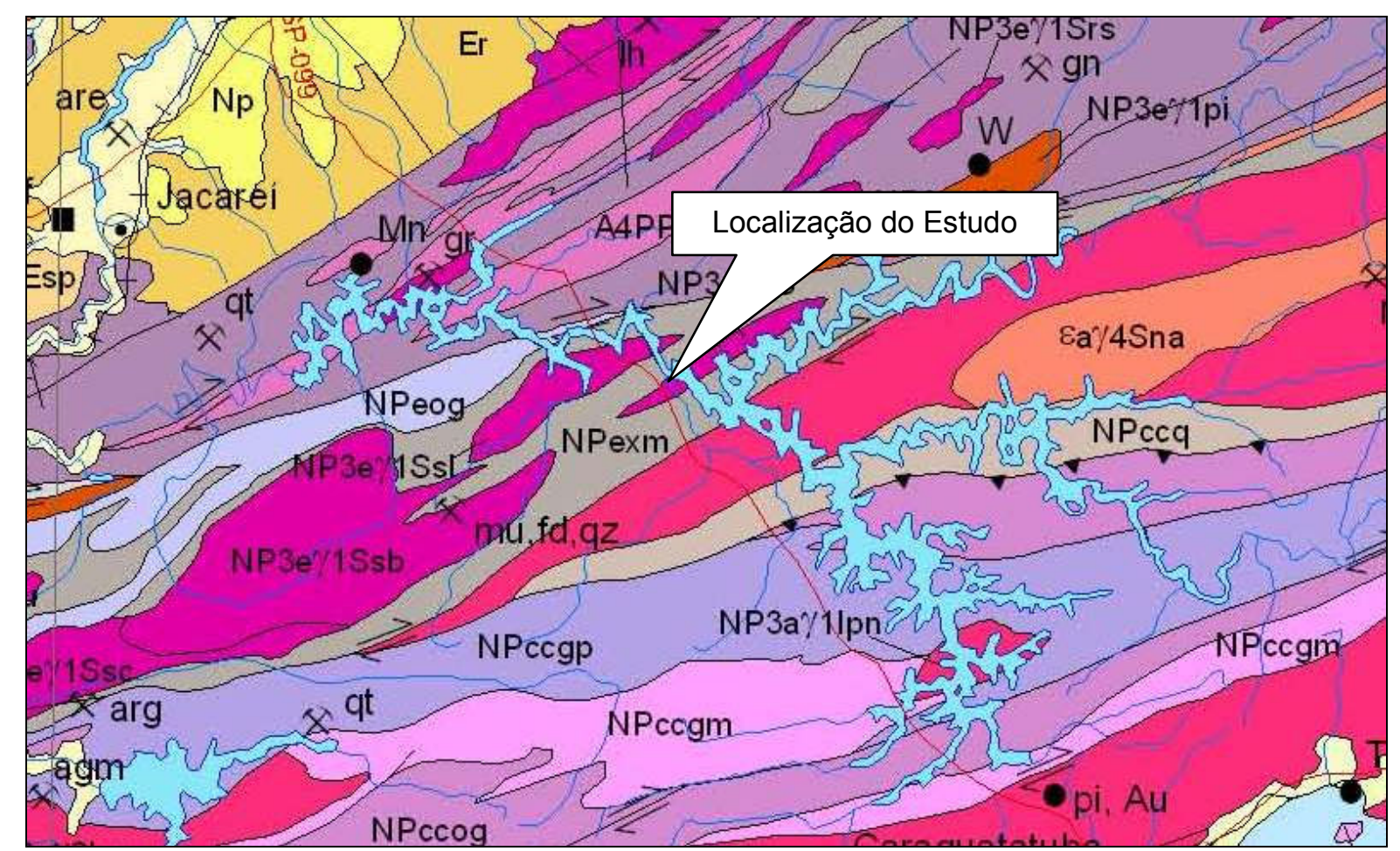

Figura 11 - Ampliação do Mapa geológico do Estado de São Paulo na área de estudo. Fonte: CPRM (2006) - modificado.

O conjunto ilustrado faz parte do complexo metamórfico definido como Grupo Açungui, de idade Pré-Cambriana Superior. 
No local, ao longo das margens do rio Paraibuna, ocorrem afloramentos dessas litologias, com predominância de estruturas xistosas, podendo aparecer depósitos eluviais e coluviais, com blocos e matacões na base das vertentes.

Aluviões recentes ocorrem no leito e em várzeas restritas, tendo em vista a característica de vale encaixado, com forte controle estrutural.

A localidade correspondente à bacia do rio Paraibuna é sustentada por migmatitos, rochas granitóides e pela faixa de xistos e quartzitos, com sistemas de relevo do tipo morros pequenos, em área com amplitudes entre 100 e $260 \mathrm{~m}$ e declividades altas.

A drenagem encaixada apresenta padrão treliçado, ora sub-paralelo, com raras e restritas planícies aluvionares, sujeitas a retrabalhamento nos períodos de cheias com arraste de material e posterior deposição na calha do rio.

\subsection{Meio Físico - Água}

A bacia hidrográfica do rio Paraíba do Sul, situada na Região Sudeste do Brasil, compreendendo parte dos Estados de São Paulo, Rio de Janeiro e Minas Gerais, apresenta grande diversidade e complexidade de uso do solo. A planície aluvial situada no trecho paulista da bacia apresenta uma crescente alteração em seu regime hídrico em razão da evaporação pela formação de lagos resultantes da atividade de extração de areia em cavas.

O rio Paraíba do Sul e seus tributários são alimentados continuamente por uma reserva subterrânea, mesmo durante o período de estiagem. Este fato ocorre devido à existência de camadas de solos permeáveis na planície aluvionar do Paraíba do Sul, principalmente nas formações Caçapava e Resende. Estes aquíferos encontram-se, geralmente, mais próximos da superfície e têm a base de drenagem localizada no leito do rio.

As bacias sedimentares de Taubaté e Rezende contém grande quantidade de cascalhos e seixos intercalados em leitos de argilas e areias em disposição entrecruzada. (CEIVAP, 1999) Essa composição e estrutura dos sedimentos funcionam como uma bacia de retenção e liberação de água de infiltração, capaz de manter o rio perene durante todo o ano. O fluxo de base pode chegar à totalidade da vazão do rio durante certas épocas do ano. 
A Política Nacional de Recursos Hídricos define o enquadramento dos corpos de água em classes de usos como importante instrumento de gestão, visando assegurar às águas, qualidade compatível com os usos mais exigentes a que forem destinadas e diminuir os custos de combate à poluição, mediante ações preventivas permanentes. Neste caso o trecho apresenta-se no enquadramento como Classe 1, em função dos usos preponderantes como: abastecimento doméstico, recreação de contato primário, proteção das comunidades aquáticas, irrigação e criação de espécies (aquicultura).

A jusante do final do trecho a ser desassoreado, o rio Paraibuna passa a ser chamado de rio Paraíba do Sul, sendo que esta denominação decorre da junção do rio Paraibuna que verte do Reservatório Paraibuna/Paraitinga (CESP) com as águas do Reservatório Santa Branca. A Figura 12 ilustra esta junção.

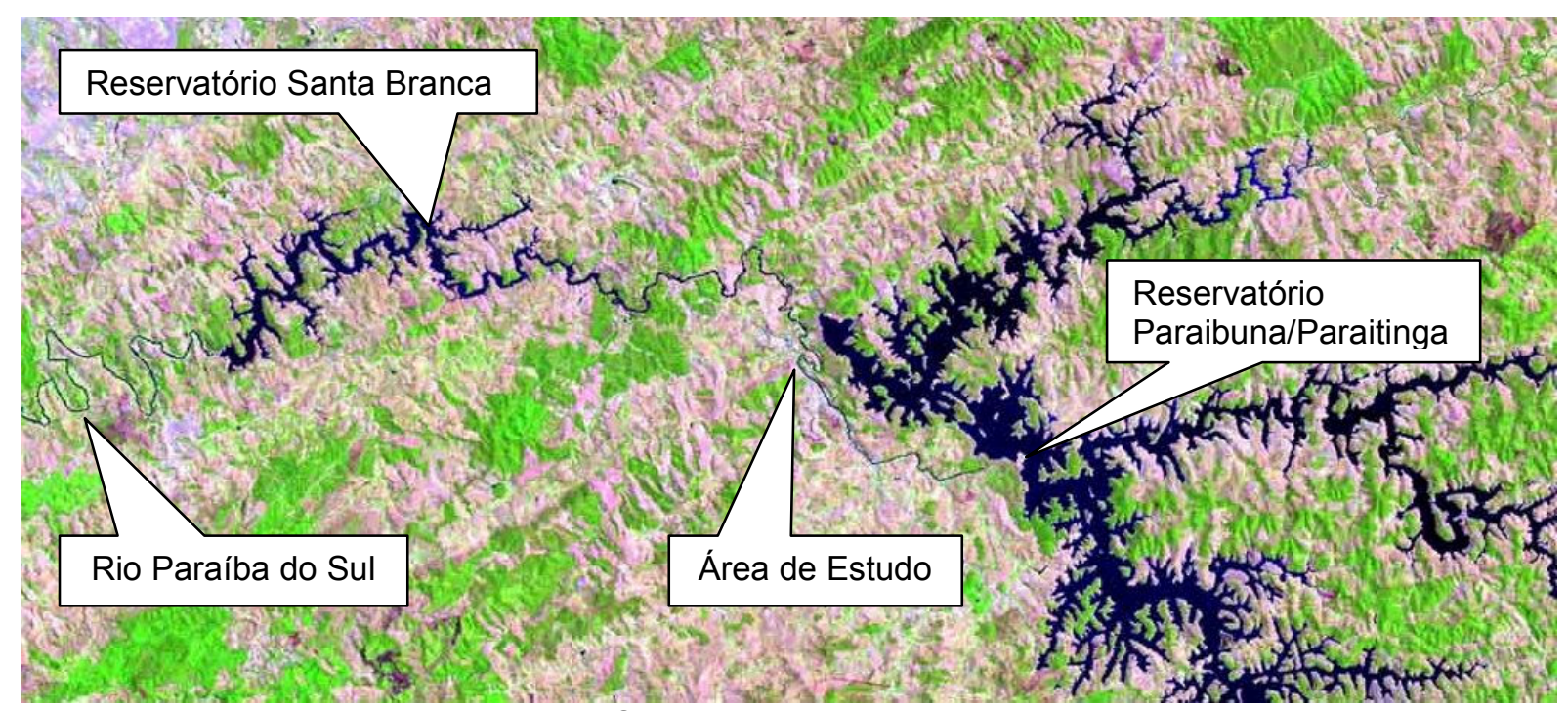

Figura 12 - Imagem de Satélite dos Reservatórios da região de estudo. Fonte: LANDSAT TM 5 (1988).

O reservatório Paraibuna/Paraitinga é parte da usina localizada no Rio Paraibuna, que tem potência total de $85 \mathrm{MW}$. A área total do seu reservatório é de $224 \mathrm{~km}^{2}$, composta pelo reservatório de Paraibuna que tem $177 \mathrm{~km}^{2}$, o qual é interligado ao reservatório de Paraitinga, com $47 \mathrm{~km}^{2}$. As barragens de Paraibuna e Paraitinga, concluídas em 1977, estão entre as mais altas do Brasil, com $104 \mathrm{~m}$ de altura. (COMPANHIA ENERGÉTICA DE SÃO PAULO, 2009)

$O$ vertedouro tulipa está localizado na barragem de Paraitinga, sua principal finalidade é regular a vazão do Rio Paraíba do Sul, responsável pelo fornecimento de água para várias cidades do Vale do Paraíba e do Estado do Rio de Janeiro. 
Vale ressaltar que este vertedouro tem papel fundamental na intensificação do processo de assoreamento devido à alteração de seu regime e intensidade de volume e fluxo de água no Rio Paraibuna. Segundo a COMPANHIA ENERGÉTICA DE SÃO PAULO a vazão média de longo termo (período 1931 - 2005) foi de $69 \mathrm{~m}^{3} / \mathrm{s}$ e a vazão defluente máxima média diária observada (23/06/83) registrou $169 \mathrm{~m}^{3} / \mathrm{s}$.

O rio Paraibuna (Alto Paraíba do Sul) nasce no município de Cunha, no bairro do Campo Alegre e então segue em direção ao sudoeste, para o bairro que tem seu nome (Bairro do Paraibuna), conforme mostra a Figura 13 da Microrregião de Paraibuna/Paraitinga.

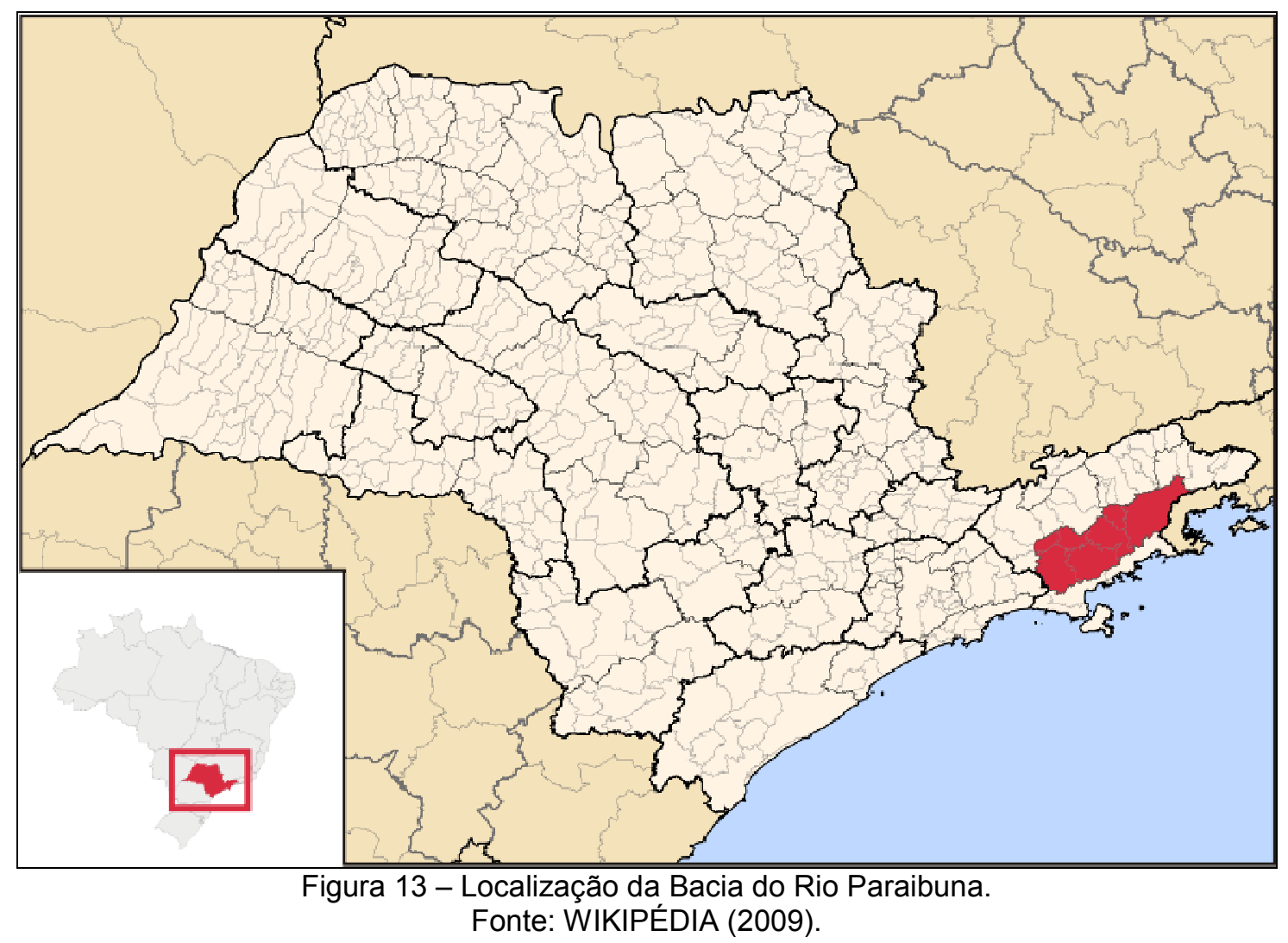

O rio atravessa o Parque Estadual da Serra do Mar, entra no Núcleo CunhaIndaiá, ainda na cidade de Cunha e sai no Núcleo Santa Virgínia.

Passa pelos municípios de São Luís do Paraitinga (próximo aos limites de Ubatuba) e Natividade da Serra, onde suas margens alargam-se bastante. No município de Paraibuna, que recebe seu nome, suas águas são aproveitadas para gerar energia elétrica. 


\subsubsection{Dinâmica Fluvial}

Uma corrente encontra-se em equilíbrio fluvial quando não se verifica, em qualquer ponto do seu curso, erosão ou deposição de material. O perfil de equilíbrio de um rio é influenciado por muitos fatores, como volume e carga da corrente, tamanho e peso da carga, declividade, entre outros. Nos pontos em que a velocidade aumenta, ocorre erosão. Já, onde há decréscimo de velocidade, tem lugar a sedimentação.

A velocidade das águas de um rio depende basicamente da declividade, do volume das águas, da forma da seção e da rugosidade do leito. Qualquer alteração destas variáveis modifica a velocidade das águas e, consequentemente, as condições de transporte, deposição ou erosão (CHRISTOFOLETTI, 1988).

Erosão, transporte e deposição de sedimentos são processos interdependentes, que se alternam, com o tempo, de acordo com a velocidade do fluxo da água e da carga existente.

Se a energia disponível para o transporte de carga sólida for suficiente, o leito do rio mantém-se em condições estáveis. Se existir um excedente de energia, esta será usada para erodir os lados e o fundo do canal, bem como transportar o material sólido que the é fornecido, contribuindo para um aumento de carga para jusante. $\mathrm{O}$ trabalho total de um rio é medido pela quantidade de material que ele é capaz de erodir, transportar e depositar.

A erosão fluvial é realizada pelos processos de abrasão, corrosão e cavitação. As águas correntes provocam erosão não só pelo impacto hidráulico, mas também por ações abrasivas e corrosivas.

$\mathrm{Na}$ abrasão, o impacto das partículas carregadas pelas águas, sobre as rochas e outras partículas, provoca um desgaste pelo atrito mecânico. Já a corrosão compreende todo e qualquer processo de reação química que se verifica entre a água e as rochas que estão e contato, resultando na dissolução de material solúvel pela percolação da água. A cavitação ocorre somente sob condições de alta velocidade da água, quando as variações de pressão, sobre as paredes do canal fluvial facilitam a fragmentação das rochas. É um fenômeno que se manifesta em vertedouros de barragens e outras obras hidráulicas onde a velocidade da água é elevada. 
A carga transportada pela corrente é fornecida pela erosão e compreende tanto o material sólido arrastado no fundo ou carregado em suspensão, quanto o material solúvel de origem diversa.

Durante o processo de transporte de partículas pelas águas correntes, elas podem se depositar de forma diferenciada, dependendo de sua granulometria, forma e densidade, fenômeno conhecido por deposição seletiva. Para uma determinada granulometria, sabe-se que as esferas decantam mais rapidamente do que os discos, bem como os minerais densos assentam-se antes dos minerais menos densos. Desta forma, as partículas mais achatadas e mais leves são favorecidas pelo processo de transporte em suspensão. Por outro lado, durante o transporte por arraste ou tração pelo fundo, as esferas rolam mais facilmente e vão deixando para trás as partículas mais achatadas.

O transporte dos sedimentos pelas correntes fluviais pode, portanto, ser agrupado nas três categorias seguintes (CARVALHO, 1994):

$>$ transporte por arraste: refere-se aos esforços tangenciais ao longo do fundo da corrente, provocados pela água em movimento, cujo efeito é reforçado pelas forças ascensionais devidas ao fluxo turbulento. $O$ transporte por arraste ou por tração é também função da forma, tamanho e densidade das partículas que constituem a carga. Quando as condições de fluxo são alteradas, por uma redução na velocidade média da corrente ou na intensidade de turbulência, as partículas maiores, mais densas e de menor esfericidade são deixadas para trás. O movimento das partículas por arraste, pelo fato de estar restrito ao leito fluvial, é mais limitado e sensível às condições de variação de velocidade e de turbulência do que o transporte por suspensão;

transporte em suspensão: ocorre quando a intensidade de turbulência é maior que a velocidade de deposição das partículas movimentadas pelos esforços tangenciais e pelas forças de ascensão. Neste caso, as partículas são carregadas de forma completamente independente do leito fluvial; e

> transporte por saltação: o deslocamento das partículas ao longo do leito fluvial se dá por série de saltos curtos. O movimento por saltação pode ser considerado como uma fase intermediária entre o transporte por tração e por suspensão. As partículas, que não são suficientemente grandes para se manterem sobre o leito, sofrendo arraste, nem suficientemente pequenas para serem transportadas em suspensão, podem ser momentaneamente 
levantadas, movendo-se para diante, em uma série de saltos e avanços sucessivos.

Uma vez iniciada a movimentação de uma partícula, os processos envolvidos no seu transporte e deposição, dependem fundamentalmente de sua velocidade de decantação. Esta depende de fatores inerentes à partícula em decantação, tais como tamanho, forma e massa específica, além de fatores ligados ao meio fluido como, por exemplo, viscosidade, massa específica, entre outros.

Como resultado do ajuste do seu canal à seção transversal, os rios podem adquirir várias formas, em função da carga sedimentar transportada, descarga líquida e declividade do canal. As formas são geralmente descritas como retilínea, anastomosada ou meandrante e todas podem ocorrer associadas em uma mesma bacia de drenagem:

canais retilíneos: possuem sinuosidade desprezível em relação à sua largura, caracterizando-se pelo baixo volume de carga de fundo, alto volume de carga suspensa e declividade acentuadamente baixa. A erosão ocorre ao longo das margens mais profundas e a deposição nas barras de sedimentos. Desenvolvem-se em planícies deltaicas de deltas construtivos, sendo de ocorrência relativamente pouco frequente na natureza;

canais anastomosados: caracterizam-se por sucessivas ramificações e posteriores reencontros de seus cursos, separando ilhas assimétricas de barras arenosas. Apresentam canais largos, não muito profundos, rápido transporte de sedimentos e contínuas migrações laterais, associadas às flutuações na vazão líquida (descarga) dos rios. Apresentam grande volume de carga de fundo e desenvolvem-se, normalmente, associados a leques aluviais, leques deltaicos, ambientes semi-áridos e planícies de lavagem de depósitos glaciais; e

canais meandrantes: são canais sinuosos, constituindo um padrão característico de rios com gradiente moderadamente baixo, cujas cargas em suspensão e de fundo encontram-se em quantidades mais ou menos equivalentes. Caracterizam-se por fluxo contínuo e regular, possuindo, em geral, um único canal que transborda as suas águas no período das chuvas. Os canais meandrantes possuem competência e capacidade de transporte mais baixas e uniformes do que os canais anastomosados, transportando 
materiais de granulometria mais fina e mais selecionada. São comuns a quase todos os setores de planícies fluviais de regiões tropicais e subtropicais úmidas. No Brasil, ocorrem vários modelos regionais de drenagens meândricas, como o do médio vale do Rio Paraíba do Sul, o do Pantanal Matogrossense e do Amazonas.

Os tipos de leitos fluviais, menor e maior, estão associados aos regimes dos rios, cujo comportamento determina a frequência e a intensidade das cheias, importantes para a manifestação de fenômenos de inundação.

O perfil longitudinal de um rio indica a sua declividade ou gradiente, constituindo-se na representação visual da relação entre a diferença total de elevação do seu leito e a extensão horizontal (comprimento) de seu curso d'água, para os diversos pontos situados entre a nascente e a foz.

A velocidade de escoamento de um rio depende da declividade dos canais fluviais: quanto maior a declividade, maior a velocidade de escoamento.

A inclinação do perfil de uma drenagem é determinada pelas condições impostas a partir de montante e pelo seu nível de base de jusante. Nível de base de um rio é o ponto mais baixo a que o rio pode chegar, sem prejudicar o escoamento de suas águas. Corresponde ao ponto, abaixo do qual, a erosão pelas águas correntes não pode atuar. O nível de base geral de quase todos os rios é o nível do mar em que suas águas chegam.

O perfil longitudinal, em toda sua extensão, resulta do trabalho que o rio executa para manter o equilíbrio entre a capacidade e a competência de um lado, com a quantidade e a granulometria da carga detrítica, de outro. O perfil longitudinal é elaborado, de forma progressiva, da foz para montante, através de processos erosivos remontantes.

O perfil longitudinal de equilíbrio da corrente apresenta forma côncava contínua, com declividade suficiente para transportar a carga do rio. As declividades do perfil são maiores em direção às cabeceiras e seus valores cada vez mais suaves à medida que o rio se aproxima da foz.

Variações na natureza dos materiais e na capacidade de transporte dos cursos d'água refletem-se na formação de camadas com características distintas. Cada camada representa uma fase de deposição e, consequentemente, tem espessura, continuidade lateral, mineralogia e granulometria particulares. 
Os aluviões são constituídos por materiais erodidos, retrabalhados e transportados pelos cursos d'água e depositados nos seus leitos e margens. São também depositados nos fundos e nas margens de lagoas e lagos, sempre associados a ambientes fluviais. Consequentemente, o pacote aluvionar é altamente heterogêneo. Entretanto, as camadas isoladas podem apresentar-se muito homogêneas.

\subsubsection{Assoreamento}

O processo de assoreamento consiste na acumulação de partículas sólidas (sedimentos) em meio aquoso ou aéreo, ocorrendo quando a força do agente transportador natural (curso d'água, vento) é sobrepujada pela força da gravidade ou quando a supersaturação das águas ou ar permite a deposição de partículas sólidas.

A intensificação do processo por atividades antrópicas decorre, em geral, diretamente da impermeabilização do solo e do aumento da erosão pluvial, por ocupações inadequadas e infra-estrutura precária de urbanização, bem como da modificação da velocidade de cursos d'água por barragens, desvios e outros. A intensificação da deposição pode acarretar assoreamento dos corpos d'água.

No sul e sudeste brasileiros, os casos de assoreamento têm se concentrado em duas situações típicas: nas áreas rurais e urbanas em regiões de solos arenosos finos e nos reservatórios de barragens, cujas bacias estão sujeitas a usos intensos do solo.

Os bancos de areia ocorrem com o assoreamento do rio e deposição de materiais. Este processo de assoreamento interfere na dinâmica hidráulica do rio, provocando aumento da velocidade da corrente próxima a uma das margens, sua erosão, o deslocamento do eixo do curso de água dando início à construção de meandros. Desta forma ocorre uma maior deposição de material sedimentar na planície do rio, potencializando o problema das inundações.

Este processo afeta também a profundidade do rio, podendo causar graves problemas para a população. Exemplo disto é o comprometimento na estrutura da ponte da Rodovia dos Tamoios cuja mudança de velocidade das águas pode causar o comprometimento da estrutura, sendo este problema já visto em outros municípios como Caçapava e Tremembé. 
A solução para estes problemas se dá pela dragagem do material depositado e a manutenção das margens do rio. A seguir, no capítulo 3, em algumas imagens do estudo-de-caso desta Dissertação podem ser observados os bancos de areia descritos acima que apresentam o problema do assoreamento no local.

Segundo a Prefeitura Municipal de Paraibuna, em 2008, o volume de areia acumulada próximo à área de captação de água era tão elevado que foram formados verdadeiros "bancos de areia", prejudicando o abastecimento da cidade, e por isto é tão importante o trabalho do desassoreamento.

\subsection{Características da Atividade de Mineração de Areia no Vale do Paraíba}

A extração de areia na várzea do rio Paraíba do Sul, para uso na construção civil, corresponde a $10 \%$ da produção nacional (VALVERDE, 2001) e equivale a 1.023.836 $\mathrm{m}^{3}$ mensais (ANUÁRIO MINERAL BRASILEIRO, 2005), respondendo por cerca de $25 \%$ da produção areeira do Estado de São Paulo. O vale do Paraíba fornece areia principalmente para atender à demanda da Região Metropolitana de São Paulo, que consome $80 \%$ de sua produção. Esta atividade mineradora se apresenta de forma ostensiva no Vale do Paraíba e pode comprometer o uso futuro das águas e das terras agricultáveis que cedem crescente espaço para as cavas.

Este comportamento do setor requer atenção quanto ao ordenamento, planejamento e aprimoramento técnico da atividade de mineração (BITAR, 2000). Entretanto, a extração de areia ocupa lugar de destaque entre as atividades econômicas da região.

A redução desta atividade, segundo TEXIER (2001), não é cogitada em nível mundial, por se constituir no principal insumo da construção civil, ainda sem um sucedâneo à altura. $O$ consumo de areia no Brasil é da ordem de 1,8 t/hab.ano. Ainda segundo o autor supra-citado, a França tem uma superfície de $547.030 \mathrm{~km}^{2}$, 60 milhões de habitantes e produz e consome 6,5 t/hab.ano de areia. 


\subsection{Impactos Ambientais}

A avaliação de impacto ambiental é constituída de uma série de procedimentos legais, institucionais e técnicos específicos, que visam identificar e prever as possíveis alterações no meio físico decorrentes da implantação e operação de empreendimentos industriais, como o mineral.

A extração de areia pode ser benéfica para a redução de impactos, se adequadamente planejada e administrada por projetos técnicos eficientes, não apresenta interações graves ou agressões ao meio ambiente. Certas alterações são, contudo, inevitáveis e encontram-se previstas nos projetos apresentados à CETESB, responsável pelo licenciamento ambiental. Ademais, com as alterações trazidas pela mineração e trabalhos de recuperação ambiental previstos nestes mesmos projetos, cada área passa a ter uma configuração mais harmônica com o meio ambiente, tendo como resultado final que na região do Vale do Paraíba, por exemplos, as cavas ou áreas mineradas possuem matas implantadas em seu entorno.

Segundo SÁNCHEZ (2007), o planejamento e a gestão ambiental na indústria de mineração integram um campo em rápida evolução. Há certamente avanços importantes em temas como: recuperação de áreas degradadas, manejo de águas em minas, monitoramento ambiental e relações com a comunidade. Porém, estes avanços são distribuídos de forma desigual, um reflexo da grande diversidade do setor mineral. Esta diversidade ocorre em escala mundial e se repete no Brasil, país onde a desigualdade é um traço marcante.

Outro ponto relevante é que, se há avanços notáveis no planejamento de novas minas e na gestão ambiental dos empreendimentos em funcionamento, ainda há um longo caminho a se percorrer no tratamento das questões socioambientais associadas ao fechamento de minas. O quadro legal e o aparato administrativo foram montados para equacionar os problemas ambientais decorrentes da abertura e do funcionamento de minas e demais atividades, mas muito pouco foi feito para tratar da situação incontornável de que minas exauridas são indústrias que ficam obsoletas e fecham (SÁNCHEZ, 2001). A desativação ambientalmente segura e socialmente responsável de minas e instalações conexas demanda planejamento concatenado com o plano de extração, em paralelo a uma cuidadosa planificação econômico-financeira, elementos ainda virtualmente ausentes no setor mineral brasileiro. 
As alterações ambientais causadas pelo funcionamento do empreendimento minerário são de pequena relevância, não prejudicando sensivelmente o meio biológico ou físico, principalmente se considerar o seu porte e as medidas de controle adotadas para minimizá-las, como é o caso de ruídos, poeira, degradação da paisagem, entre outros.

Já a dragagem submersa tem como objetivo restabelecer a profundidade e o regime fluvial no trecho compreendido entre os reservatórios da Usina Hidrelétrica Paraibuna e da Usina Hidrelétrica Santa Branca que são os principais reguladores das vazões do Rio Paraíba do Sul, além de normalizar o sistema de captação e adução de água para o município de Paraibuna/SP. 


\section{MÉTOdOS APLICADOS DE CAMPO}

Conforme já citado, este trabalho abordará a extração de areia através da dragagem hidráulica em leitos submersos, no trecho do Rio Paraibuna, localizado no município de Paraibuna/SP, em razão da degradação por assoreamento que ocorre no local.

\subsection{Vistoria}

Foi realizada, inicialmente, uma vistoria na área no dia 20 de agosto de 2008, sendo constatado, principalmente no desague do córrego sem denominação pela margem esquerda do Rio Paraibuna, o assoreamento de material arenoso, com uma lâmina da água de aproximadamente $0,20 \mathrm{~m}$.

Ao longo do trecho do rio Paraibuna, onde se pretende executar a obra de desassoreamento, foi observada a existência de erosões nos taludes das margens, especialmente em sua margem esquerda, onde o rio tangencia o talude da Avenida São José e em sua curva na parte externa. Observou-se nas proximidades do ponto de captação de água da Prefeitura Municipal de Paraibuna, a existência de uma ilha formada por um banco de areia e um bambuzal, resultando na presença de assoreamento em sua extensão.

A Figura 14 possibilita a visualização de pontos de assoreamento no decorrer do Rio Paraibuna, seguida da Figura 15, onde visualiza-se outro trecho, a montante da área, também assoreado que corresponde ao ponto de captação de água no município de Paraibuna. 


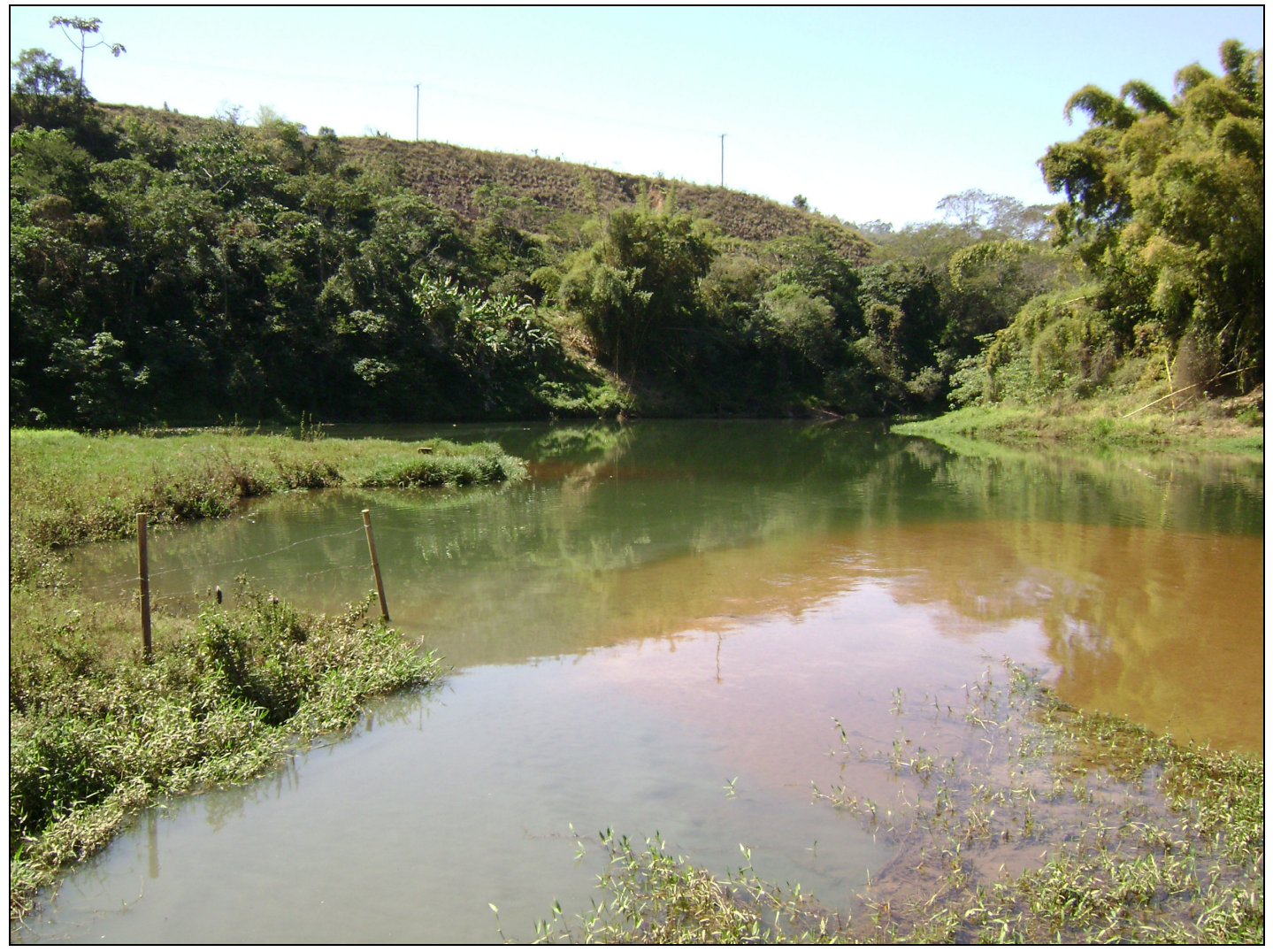

Figura 14 - Trecho do Rio Paraibuna, área de estudo. (20/08/08)

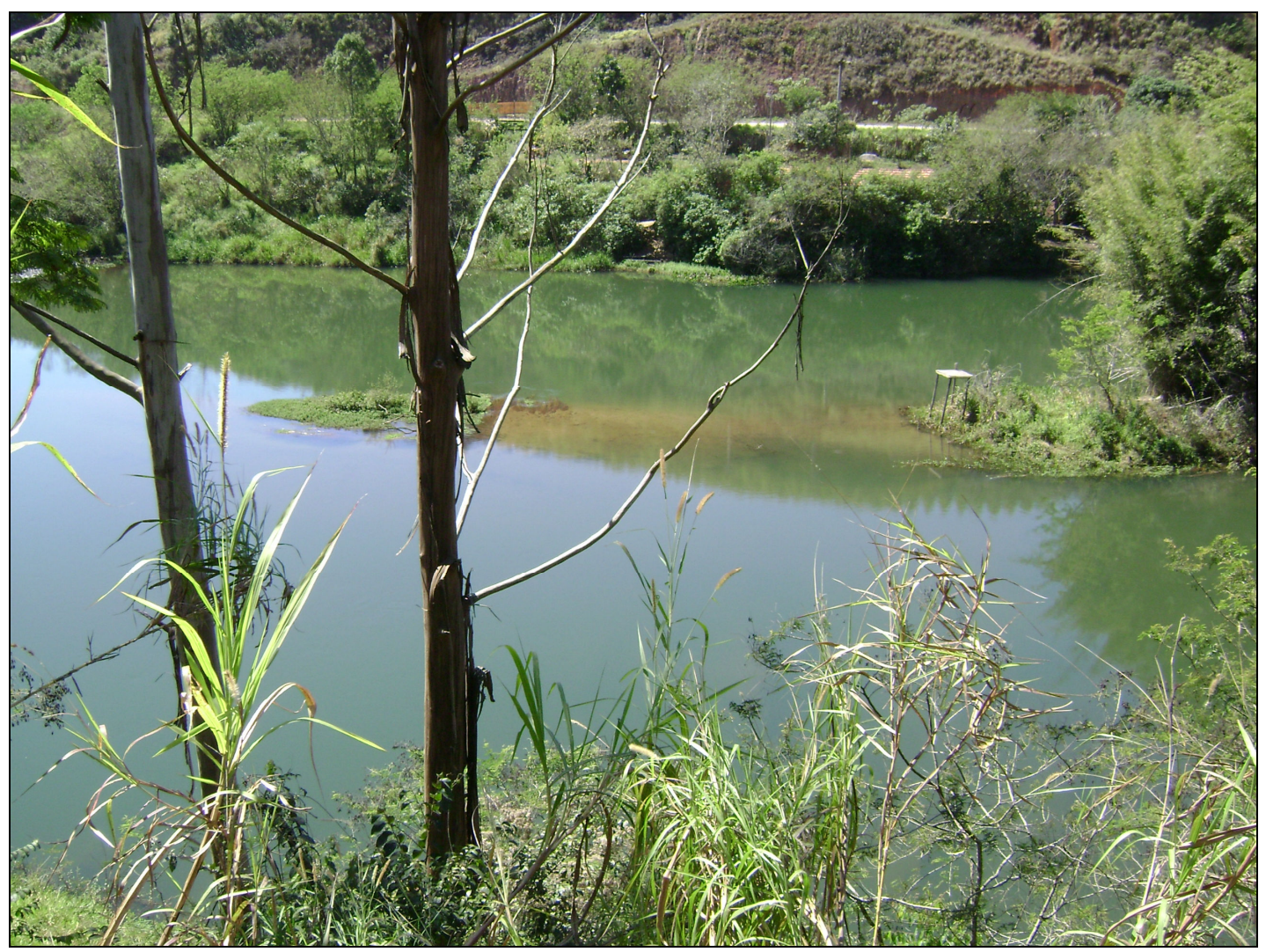

Figura 15 - Trecho do Rio Paraibuna, ponto de captação de água. (20/08/08) 
A reposição dos sedimentos, nas condições do leito do rio, é bastante variável, podendo acorrer de diversas formas como gradiente do leito, topografia da região, chuvas a montante, meandros do rio, geologia das rochas e sedimentos do entorno. Estes fatores, entre outros, influenciam no regime de redeposição.

\subsection{Investigação da Área}

Para verificação da situação do leito do trecho estudado do rio Paraibuna e caracterização do material foram realizados estudos batimétricos e análise em laboratório que avaliaram os sedimentos arenosos que compõem o leito ativo do rio, como segue:

\subsubsection{Amostragem}

A amostragem foi conduzida através das seguintes etapas:

> localização dos pontos entre as seções batimétricas;

$>$ coleta do material no leito sub-superficial;

$>$ identificação de cada amostra;

armazenamento das amostras para análises de caracterização tecnológica; e

envio ao laboratório.

A amostragem foi determinada pela área da obra de desassoreamento, sendo coletadas amostras de aproximadamente $3 \mathrm{~kg}$ do sedimento nos pontos onde foi possível através do método de coleta descrito. A Figura 16 apresenta os pontos de amostragem para análises físico-químicas e mineralógicas e a área delimitada para a obra de desassoreamento. 


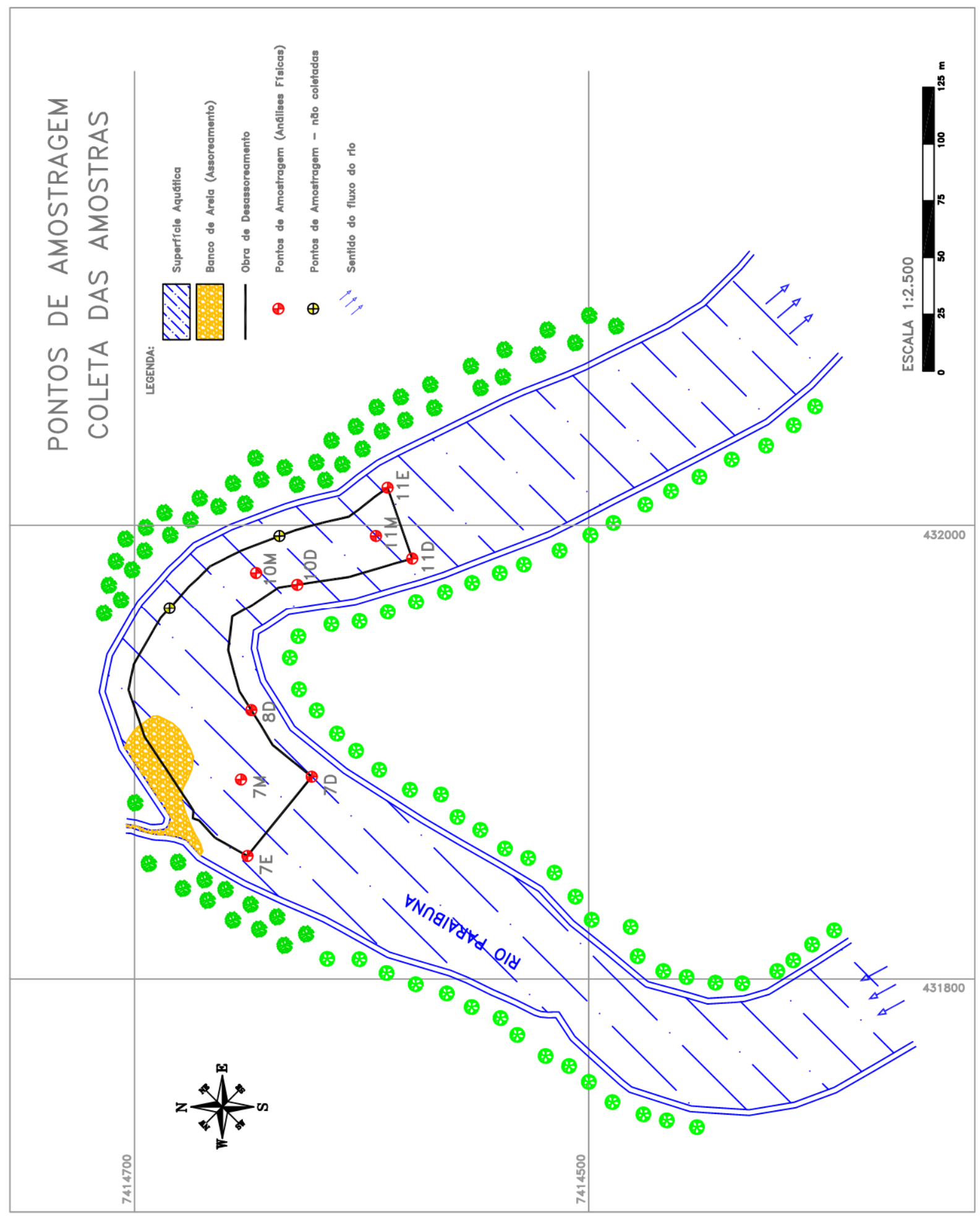

Figura 16 - Localização dos pontos de retirada de amostras.

\subsubsection{Batimetria}

De acordo com o proprietário ${ }^{4}$ da área procedeu-se na área através do método de batimetria a identificação do assoreamento nos trechos em questão,

${ }^{4}$ PIZA, S. C. T. Comunicação Pessoal, 2009. 
objetivando a medição do corpo de areia existente no rio Paraibuna para elaboração do projeto de desassoreamento nos corpos de areia identificados, visando o reaproveitamento deste material.

A campanha de sondagem realizada para obter informações da sub superfície do leito foi realizada ao longo de linhas transversais ao eixo longitudinal do rio.

A sondagem a varejão é feita com uma haste lisa de ferro, cravada manualmente, ou com golpes de marreta, em sedimentos inconsolidados submersos. É usada para o reconhecimento de aluviões, superfícies rochosas no leito de um rio e para avaliar depósitos de areia e cascalho para uso na construção civil.

A haste geralmente penetra até $3 \mathrm{~m}$ no aluvião arenoso inconsolidado e o material atravessado pode ser identificado pela reação sonora e vibratória do processo. Em argila, a penetração é macia, em areia é áspera e em depósitos de areia com cascalho observam-se bloqueios esparsos na cravação da haste. Bancos consolidados de cascalho não são penetrados pelo varejão. Em superfície rochosa o impacto é duro e resvala.

No caso de jazidas de areia, executa-se uma malha de sondagens a varejão, que consiste na cravação por uma pessoa, sem impacto, de uma haste metálica lisa, por exemplo - ferro de construção de $1 / 2$ ". As profundidades atingidas em cada ponto devem ser anotadas.

A batimetria e a sondagem a varejão foram realizadas em 7 perfis espaçados de $700 \mathrm{~m}$ no eixo longitudinal do rio Paraibuna, sendo que em cada perfil foram realizadas 4 sondagens (espaçadas de $10 \mathrm{~m}$ ).

Ao longo das seções utilizadas na sondagem foi determinado o relevo do fundo do rio através, de batímetro, para possibilitar a determinação volumétrica do depósito.

O volume de areia explotável foi obtido através do cálculo das medidas das espessuras em cada ponto de sondagem, em cada seção, considerando a área de influência de cada ponto e foram realizadas amostragens nas seções para a caracterização do material. 


\subsection{Caracterização Tecnológica Preliminar}

O conhecimento mais detalhado da mineralogia e da textura dos minérios, rejeitos e concentrados permite um processo mais ajustado e consequentemente maior eficiência na recuperação do bem mineral de interesse, menor descarte de material com potencial econômico e mais responsabilidade ambiental, num contexto de menor consumo energético e de água.

\subsubsection{Análise Física - Peneiramento e Sedimentação}

A distribuição granulométrica dos materiais granulares, areias e pedregulhos, foram obtidos através do processo de peneiramento de uma amostra seca em estufa, enquanto que, para siltes e argilas se utiliza à sedimentação dos sólidos no meio líquido. Para solos, que tem partículas tanto na fração grossa (areia e pedregulho) quanto na fração fina (silte e argila) se torna necessária a análise granulométrica conjunta.

As análises granulométricas dos sedimentos do leito foram feitas por peneiramento e sedimentação seguindo a NBR 7181/88 (Solo - Análise granulométrica).

A separação dos sólidos, de um solo, em diversas frações é o objetivo do peneiramento. Este processo é adotado para partículas (sólidos) com diâmetros maiores que 0,075mm (\#200). Para tal, utiliza-se uma série de peneiras de abertura de malhas conhecidas (Figura 17), determinando-se a percentagem em peso retida ou passante em cada peneira. Este processo divide-se em peneiramento grosso, partículas maiores que $2 \mathrm{~mm}$ (\#10) e peneiramento fino, partículas menores que $2 \mathrm{~mm}$. 


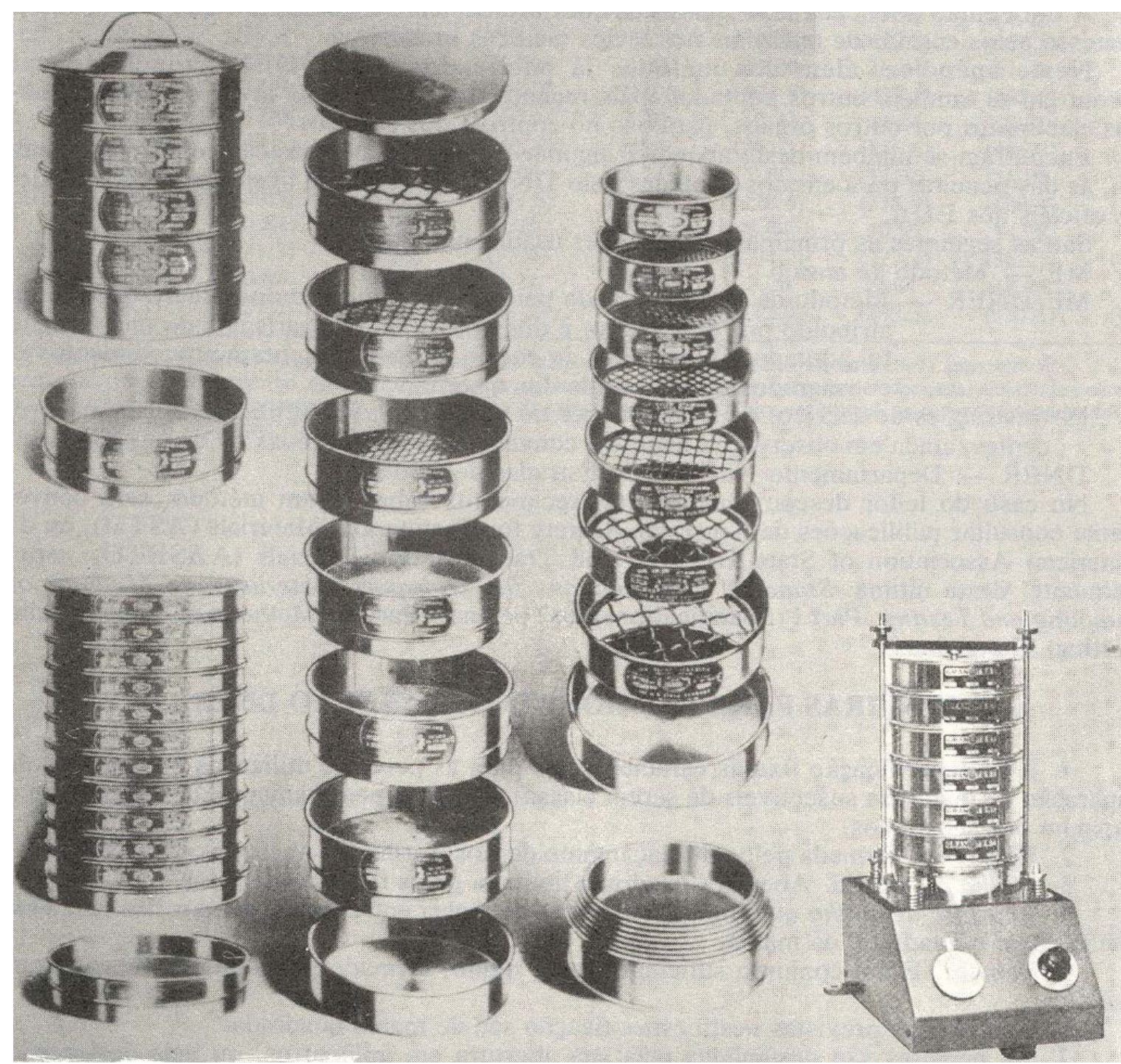

Figura 17 - Série de peneiras de abertura de malhas. Fonte: NBR NM ISO 3310-1 (1997).

Para o peneiramento de um material granular, a amostra é, inicialmente, secada em estufa e seu peso determinado. Esta amostra será colocada na peneira de maior abertura da série previamente determinada pela NBR NM ISO 3310-1/1997 (Peneiras de ensaio - Requisitos técnicos e verificação) e levada a um vibrador de peneiras onde permanecerá pelo tempo necessário à separação das frações.

Quanto ao solo, possui uma porcentagem grande de finos, em geral não interessa a sua distribuição granulométrica, faz-se, primeiramente, uma lavagem do solo na peneira $n^{\circ} 200$, seguido da secagem em estufa do material retido e posterior peneiramento. Este procedimento leva a resultados mais corretos do que fazer o peneiramento direto, da amostra seca.

Já para a sedimentação os solos finos, siltes e argilas, com partículas menores que 0,075mm (\#200), o cálculo dos diâmetros equivalentes foi feito a partir 
dos resultados obtidos durante a sedimentação de certa quantidade de sólidos em um meio líquido.

No total foram realizadas nove análises no Laboratório de Mecânica dos Solos do Departamento de Engenharia Civil, Ambiental e Sanitária da UNITAU Universidade de Taubaté, sendo seis análises no processo de peneiramento e três na análise conjunta.

\subsubsection{Teor de Impurezas Orgânicas}

A matéria orgânica é a impureza mais frequente nas areias. São detritos, mais comumente de origem vegetal, que estão geralmente sob a forma de partículas minúsculas, mas em grande quantidade chegam a escurecer o agregado miúdo.

A matéria orgânica pode prejudicar a "pega", o endurecimento das argamassas e concretos e a sua resistência mecânica. O ensaio colorimétrico, de acordo com a NBR NM 49/01 (Agregado miúdo - Determinação de impurezas orgânicas), indica a existência ou não de impurezas orgânicas nas areias.

A análise foi conduzida por teste semi-quantitativo e colorimétrico, onde foram utilizados como reagentes a solução de hidróxido de sódio a $3 \%$ e a solução padrão de ácido tânico a $2 \%$. Cada amostra de material foi colocada em um frasco Erlenmeyer com $100 \mathrm{ml}$ da solução de hidróxido de sódio e agitadas vigorosamente. Posteriormente foram deixadas em repouso durante 24 horas. Simultaneamente ao procedimento descrito, foi preparada uma solução padrão, adicionando a $97 \mathrm{ml}$ da solução de hidróxido de sódio, $3 \mathrm{ml}$ da solução de ácido tânico a $2 \%$. Esta solução foi agitada e deixada em repouso por 24 horas. Após o período de repouso, as soluções que estiveram em contato com os agregados foram filtradas e recolhidas em um tubo de ensaio e a solução padrão transferida para um tubo de ensaio.

A quantidade de matéria orgânica foi avaliada comparando a cor das soluções obtidas com a da solução padrão. A cor de cada solução deve ser mais clara que a da solução padrão, que indica um teor de impureza orgânica inferior a 200 ppm.

Para esta analise foram encaminhadas três amostras para o laboratório do Departamento de Construção Civil da EPUSP a fim de verificar os teores nos pontos a montante, central e jusante da área da obra de desassoreamento. 


\subsubsection{Análise Química - Fluorescência de Raios X}

A caracterização química e mineralógica da areia é importante para a determinação das suas propriedades, permitindo melhor aplicação de acordo com o uso destinado à Construção Civil.

As amostras de sedimentos foram analisadas por esta técnica, que visa fornecer informações quantitativas sobre a composição química dos materiais.

Os raios X foram descritos por Wilhelm Roentger, em 1895. Quando esta radiação incide na matéria, vários fenômenos acontecem, e o feixe é atenuado, tanto por absorção como por espalhamento. A absorção é mais significativa e cresce com o número atômico da substância, fazendo com que materiais heterogêneos apresentem diferentes atenuações, em função do número atômico médio das diferentes áreas irradiadas. A primeira aplicação desta radiação foi demostrada pelo próprio Roentger, que publicou um trabalho em 1898 onde exibia a radiografia da mão de sua esposa, com os ossos perfeitamente visíveis, segundo RATTI (2009).

Para análise química total (determinação dos elementos maiores, menores e traços), as amostras de sedimento foram moídas em moinho com panelas de tungstênio e o pó resultante foi prensado em pastilhas. Estas pastilhas foram analisadas em Espectrômetro de Fluorescência de Raio X (FRX) modelo Axios Advantage da Panalytical no Laboratório de Caracterização Tecnológica (LCT) do Departamento de Engenharia de Minas e Petróleo da EPUSP.

Foram encaminhadas três amostras para o laboratório a fim de verificar a composição mineralógica nos pontos a montante, central e jusante da área da obra de desassoreamento.

\subsubsection{Composição Mineralógica - Difração de Raios X}

A análise por Difração de Raios X (DRX) objetiva a identificação das fases cristalinas, incluindo-se tanto minerais constituintes dos agregados, como os produtos cristalinos da reação álcali-agregado, entre outros mecanismos.

A difratometria de raios $X$ corresponde a uma das principais técnicas de caracterização microestrutural de materiais cristalinos, encontrando aplicações em diversos campos do conhecimento, mais particularmente na Engenharia e Ciências 
de Materiais, Engenharias Metalúrgica, Química e de Minas, além de Geociências, dentre outros.

Os raios $\mathrm{X}$ ao atingirem um material podem ser espalhados elasticamente, sem perda de energia pelos elétrons de um átomo (dispersão ou espalhamento coerente). $O$ fóton de raios $X$, após a colisão com o elétron, muda sua trajetória, mantendo, porém, a mesma fase e energia do fóton incidente. Sob o ponto de vista da física ondulatória, pode-se dizer que a onda eletromagnética é instantaneamente absorvida pelo elétron e reemitida; cada elétron atua, portanto, como centro de emissão de raios $X$ segundo KAHN (2009).

A amostra foi analisada pelo mesmo método no difratômetro de raios $X$ (DRX), marca Phillips - modelo MPD 1880, localizado no LCT do Departamento de Engenharia de Minas e Petróleo da EPUSP.

Assim como havia sido definido, a amostra 10D também foi submetida a análise de difração de raios $X$, fechando a composição mineralógica para este estudo. 


\section{RESULTADOS E DISCUSSÕES}

O trecho objeto compreende duas curvas da calha do rio, ambas para a direita, onde está ocorrendo uma sedimentação predominante na margem direita (menor fluxo) e um processo erosivo acentuado na margem esquerda, principalmente nos locais onde o rio tangencia o talude da avenida de acesso ao município.

Outro local em que pode ser observado um processo erosivo é na parte externa da segunda curva deste trecho de rio, onde se localiza um pequena estrada de servidão junto ao talude da Rodovia dos Tamoios. Apesar da composição rochosa destes taludes, a presença de porções de rocha alterada, depósitos coluvionares e aterros, diminuem a resistência aos processo erosivos.

No local já foram realizadas atividades de contenção de erosão para preservação do talude da avenida de acesso, porém para minimizar o processo erosivo nos pontos citados é necessário uma obra de desassoreamento, para o aprofundamento da calha do rio na porção mais próxima à margem direita deste. Esta operação de dragagem estabelecerá uma linha de maior fluxo hídrico (energia) próximo à margem direita, diminuindo este efeito erosivo sobre a margem esquerda. Outro efeito gerado pelo desassoreamento do leito será o aumento da vazão, diminuindo o potencial de inundação em período de cheias.

$\mathrm{Na}$ área em estudo, a geologia está representada por uma sequência de sedimentos, tipicamente de ambiente fluvial, inconsolidados, com cascalhos na base e areias nas mais diversas granulometrias, com estratificações cruzadas e acanaladas, eventualmente com níveis e lentes argilosas intercaladas.

\subsection{Perfis da Batimetria}

A verificação do leito foi através da batimetria que avaliou os depósitos de sedimentos arenosos que compõe o leito ativo do rio Paraibuna. Estes depósitos se caracterizaram por feições de "barra em pontal" e "barras de canal", predominantemente arenosos, recobrindo diretamente os siltitos e folhelhos terciários.

A Figura 18 apresenta seções de batimetria ao longo do trecho e a Figura 19 os perfis da batimetria correspondentes. 


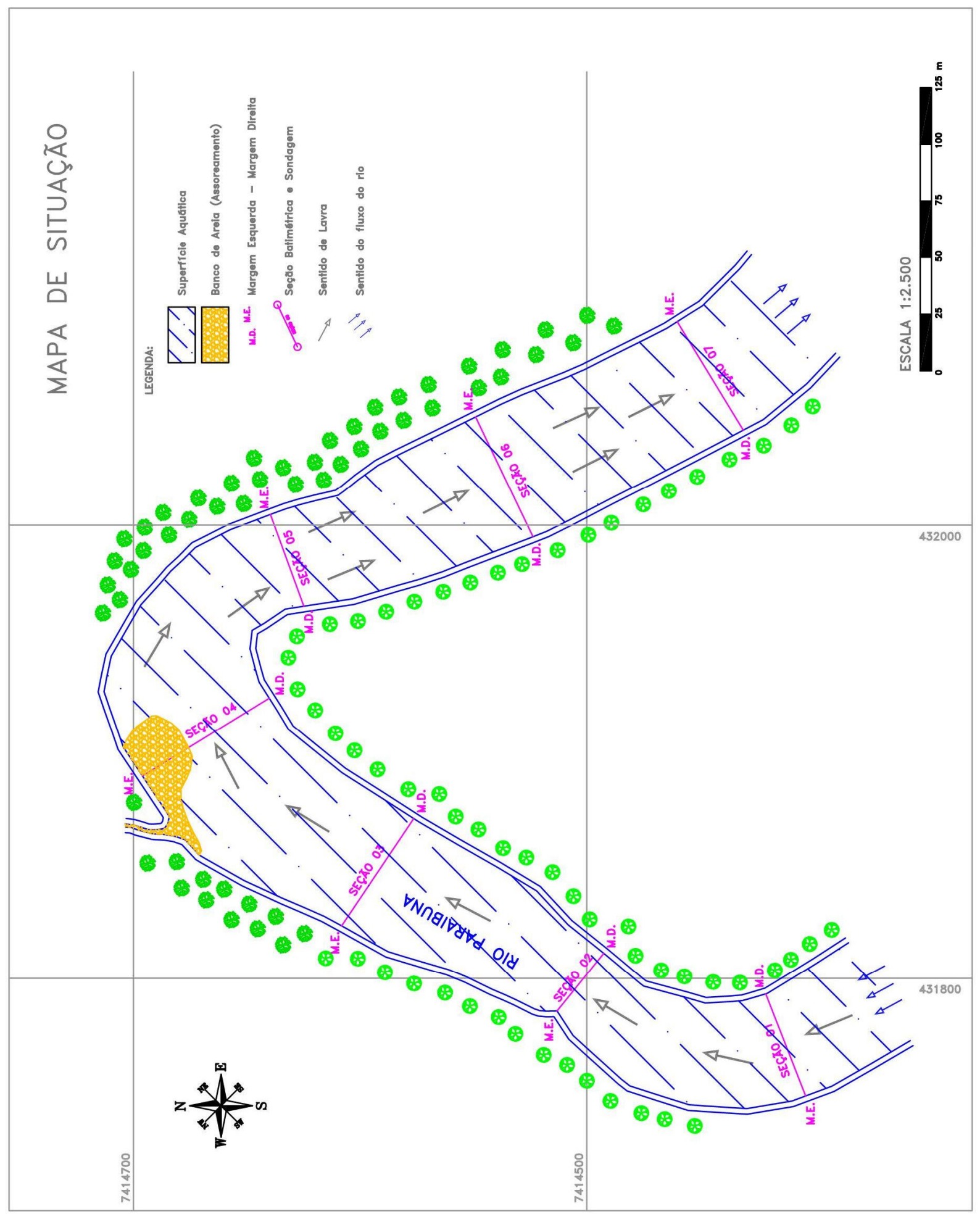

Figura 18 - Localização das seções de batimetria e sondagens no Rio Paraibuna. 

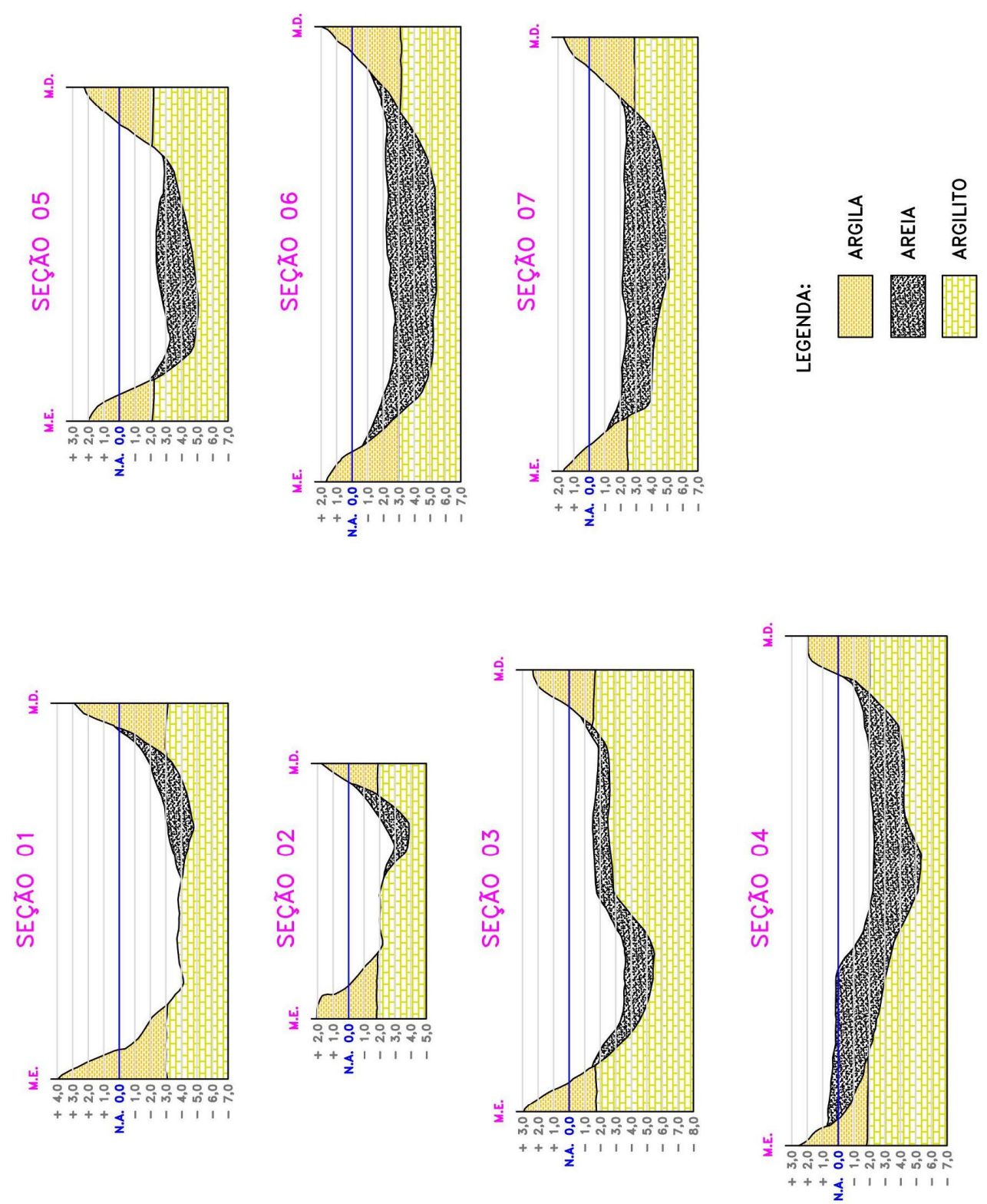

Figura 19 - Detalhe das seções de batimetria e sondagens. 


\subsection{Determinação do Volume de Areia}

Baseado nos perfis batimétricos apresentados, foi calculado o volume de material estimado, multiplicando-se a área da fonte de material pela profundidade média explotável estimada ou determinada por sondagens expeditas.

Outro fator que possibilitou determinar o volume estimado de material foi a verificação em outros pontos de explotação na região, quanto a percentagem de aproveitamento de areia.

Assim pela média das seções, ficou estabelecido um volume de $61.000 \mathrm{~m}^{3}$ de sedimento, composto por $90 \%$ de areia $\left(54.900 \mathrm{~m}^{3}\right), 8 \%$ de silte e argilas $(4.880$ $\mathrm{m}^{3}$ ) e $2 \%$ de cascalhos $\left(1.220 \mathrm{~m}^{3}\right)$. Todo este material poderá ser comercializado.

A capacidade de beneficiamento do equipamento a ser instalado para a obra de desassoreamento será, a princípio, de $4.000 \mathrm{~m}^{3} / \mathrm{mês}$ de areia comercial, o que pressupõe um período de 14 meses para a execução da obra.

Desta forma, com o plano de uma escala de produção aproveitável de 4000 $\mathrm{m}^{3} /$ mês e a média de valor econômico para a areia beneficiada no valor de $\mathrm{R} \$$ $25,00 / \mathrm{m}^{3}$, obtém-se uma receita estimada de $\mathrm{R} \$ 90.000,00 /$ mês, descontando-se perdas de materiais no beneficiamento e em custos de comercialização.

\subsection{Análises Físico-químicas}

Os resultados apresentados na caracterização dos agregados são de distribuição granulométrica por peneiramento e sedimentação, de impurezas orgânicas, além da análise de composição mineralógica por difratometria de raios $X$ e análises químicas por FRX.

Neste sentido, uma caracterização mineralógica e tecnológica adequadas são essenciais para o maior retorno do investimento e uso responsável e sustentado de recursos naturais não renováveis. 


\subsubsection{Análise Física - Peneiramento e Sedimentação}

As análises físicas do solo foram efetuadas no Laboratório de Mecânica dos Solos do Departamento de Engenharia Civil, Ambiental e Sanitária da UNITAU Universidade de Taubaté, empregando-se a metodologia descrita na NBR 7181/88 e NBR $7211 / 09$.

Os resultados da granulometria são apresentados nas Tabelas 4 a 12 e Figuras 20 a 29 a seguir. 
Tabela 4 - Análise Granulométrica amostra 7D

\begin{tabular}{c|c|c|c|c}
\hline \% Argila e Silte & \% Areia Fina & \% Areia Média & \% Areia Grossa & $\%$ Pedregulho \\
\hline $19,75 \%$ & $78,28 \%$ & $1,98 \%$ & $0,00 \%$ & $0,00 \%$ \\
\hline
\end{tabular}

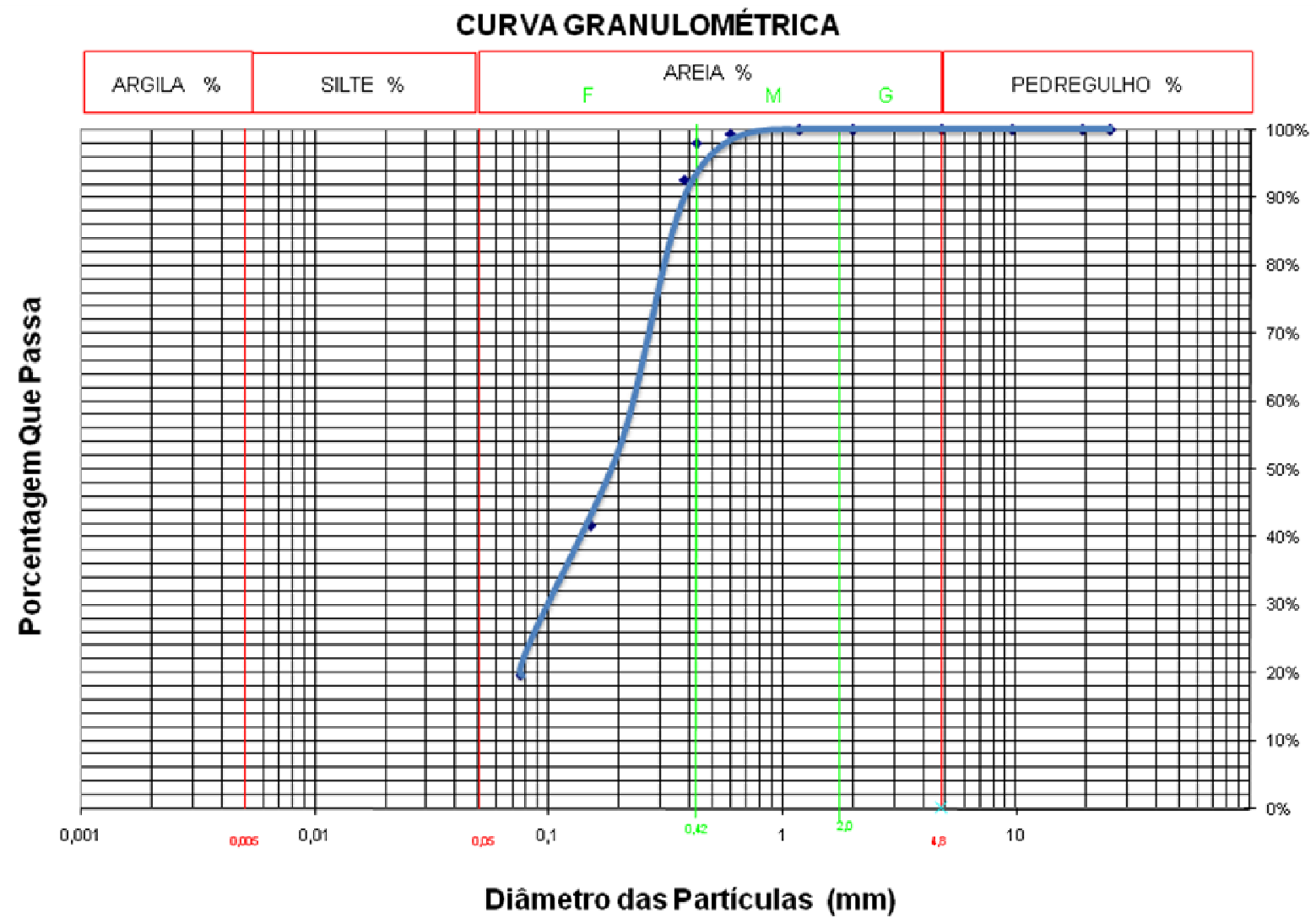

Figura 20 - Curva granulométrica amostra 7D.

Fonte: UFJF - Laboratório de Mecânica dos Solos I.

Notas: Faixa de argila $0,001-0,005 \mathrm{~mm}$; silte $0,005-0,05 \mathrm{~mm}$; areia fina $0,05-0,42 \mathrm{~mm}$; areia média $0,42-2,0 \mathrm{~mm}$; areia grossa $2,0-4,8 \mathrm{~mm}$ e pedregulho $>4,8 \mathrm{~mm}$. 
Tabela 5 - Análise Granulométrica amostra 7M

\begin{tabular}{c|c|c|c|c}
\hline \% Argila e Silte & \% Areia Fina & \% Areia Média & $\%$ Areia Grossa & $\%$ Pedregulho \\
\hline $10,95 \%$ & $6,47 \%$ & $74,94 \%$ & $7,24 \%$ & $0,40 \%$ \\
\hline
\end{tabular}

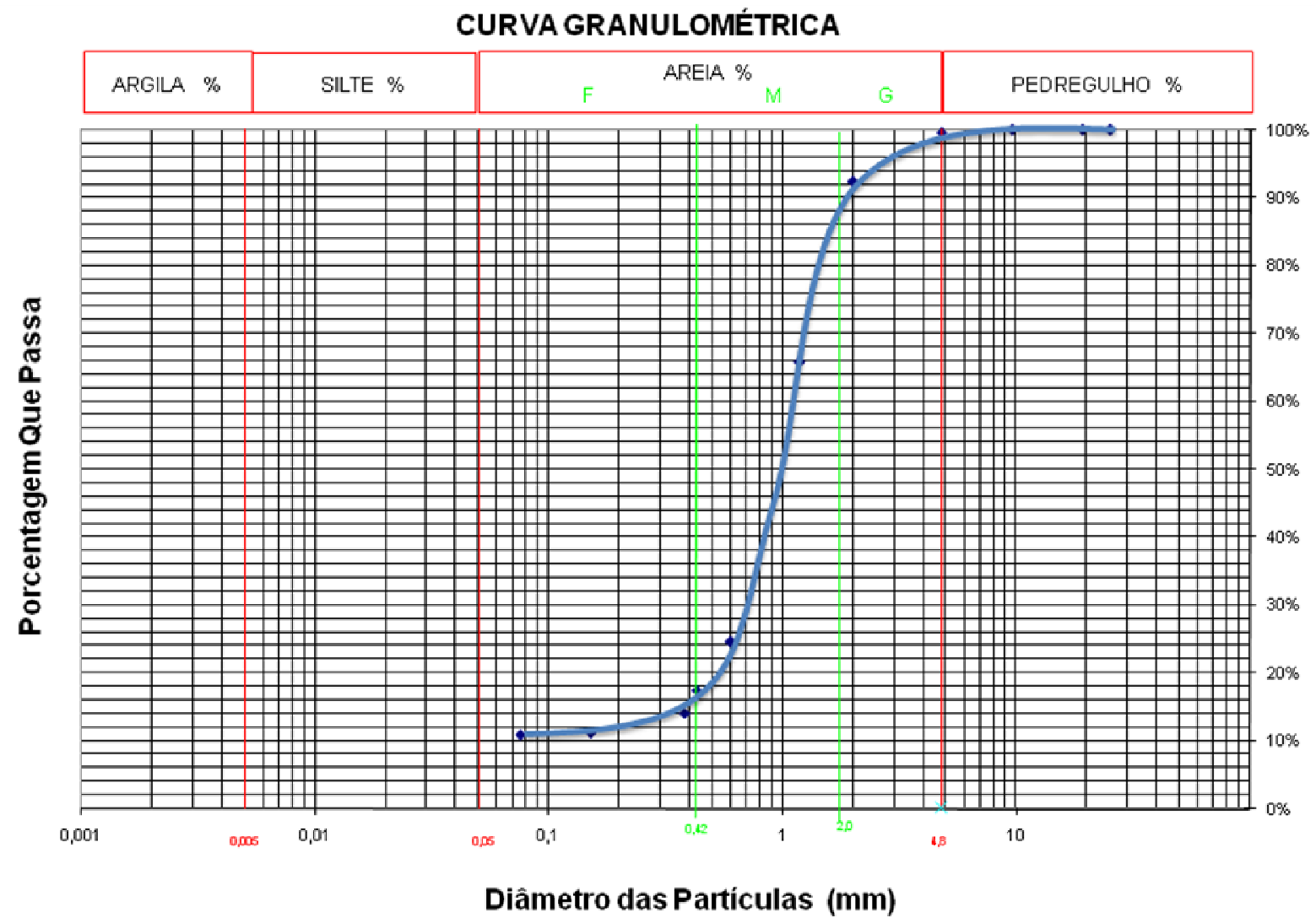

Figura 21 - Curva granulométrica amostra $7 \mathrm{M}$.

Fonte: UFJF - Laboratório de Mecânica dos Solos I.

Notas: Faixa de argila $0,001-0,005 \mathrm{~mm}$; silte $0,005-0,05 \mathrm{~mm}$; areia fina $0,05-0,42 \mathrm{~mm}$; areia média $0,42-2,0 \mathrm{~mm}$; areia grossa $2,0-4,8 \mathrm{~mm}$ e pedregulho $>4,8 \mathrm{~mm}$. 
Tabela 6 - Análise Granulométrica amostra 7E

\begin{tabular}{c|c|c|c|c}
\hline$\%$ Argila e Silte & \% Areia Fina & \% Areia Média & \% Areia Grossa & $\%$ Pedregulho \\
\hline $72,69 \%$ & $22,16 \%$ & $3,20 \%$ & $1,39 \%$ & $0,56 \%$ \\
\hline
\end{tabular}

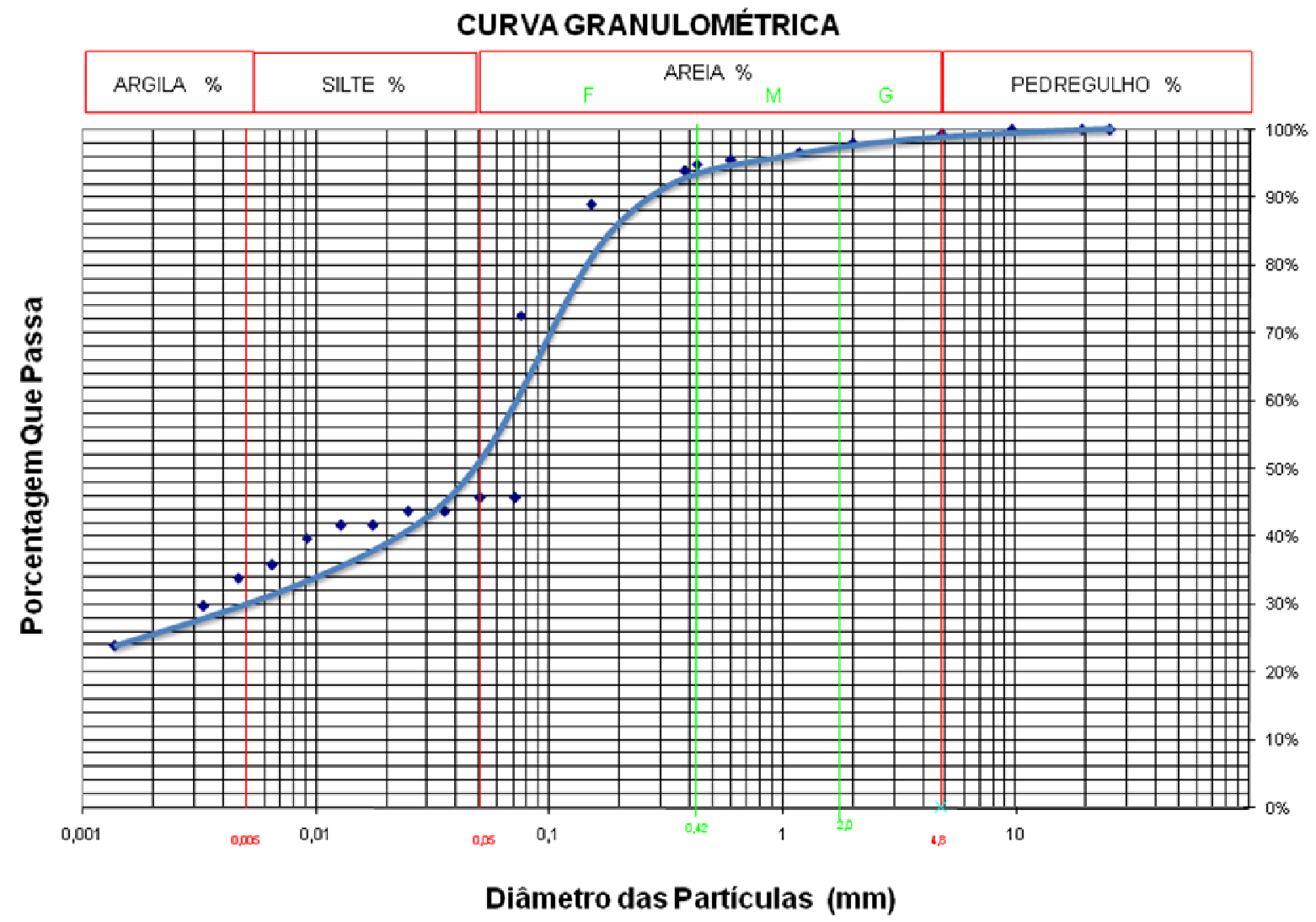

Figura 22 - Curva granulométrica amostra 7E.

Fonte: UFJF - Laboratório de Mecânica dos Solos I.

Notas: Faixa de argila $0,001-0,005 \mathrm{~mm}$; silte $0,005-0,05 \mathrm{~mm}$; areia fina $0,05-0,42 \mathrm{~mm}$; areia média $0,42-2,0 \mathrm{~mm}$; areia grossa $2,0-4,8 \mathrm{~mm}$ e pedregulho $>4,8 \mathrm{~mm}$. 
Tabela 7 - Análise Granulométrica amostra 8D

\begin{tabular}{c|c|c|c|c}
\hline \% Argila e Silte & \% Areia Fina & \% Areia Média & \% Areia Grossa & $\%$ Pedregulho \\
\hline $15,47 \%$ & $48,35 \%$ & $13,71 \%$ & $3,32 \%$ & $19,15 \%$ \\
\hline
\end{tabular}

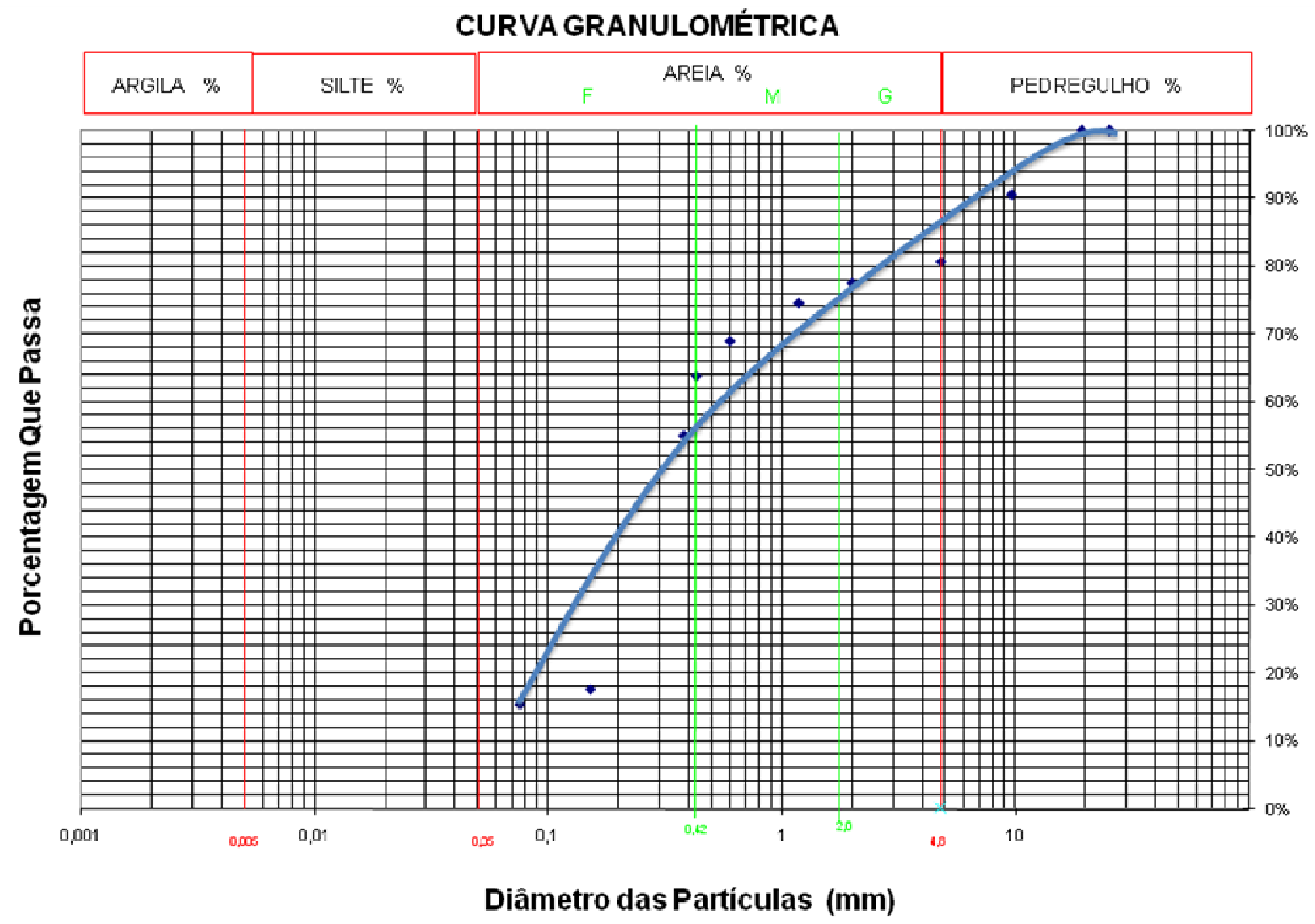

Figura 23 - Curva granulométrica amostra 8D.

Fonte: UFJF - Laboratório de Mecânica dos Solos I.

Notas: Faixa de argila $0,001-0,005 \mathrm{~mm}$; silte $0,005-0,05 \mathrm{~mm}$; areia fina $0,05-0,42 \mathrm{~mm}$; areia média $0,42-2,0 \mathrm{~mm}$; areia grossa $2,0-4,8 \mathrm{~mm}$ e pedregulho $>4,8 \mathrm{~mm}$. 
Tabela 8 - Análise Granulométrica amostra 10D

\begin{tabular}{c|c|c|c|c}
\hline \% Argila e Silte & \% Areia Fina & \% Areia Média & $\%$ Areia Grossa & $\%$ Pedregulho \\
\hline $5,78 \%$ & $89,79 \%$ & $4,43 \%$ & $0,00 \%$ & $0,00 \%$ \\
\hline
\end{tabular}

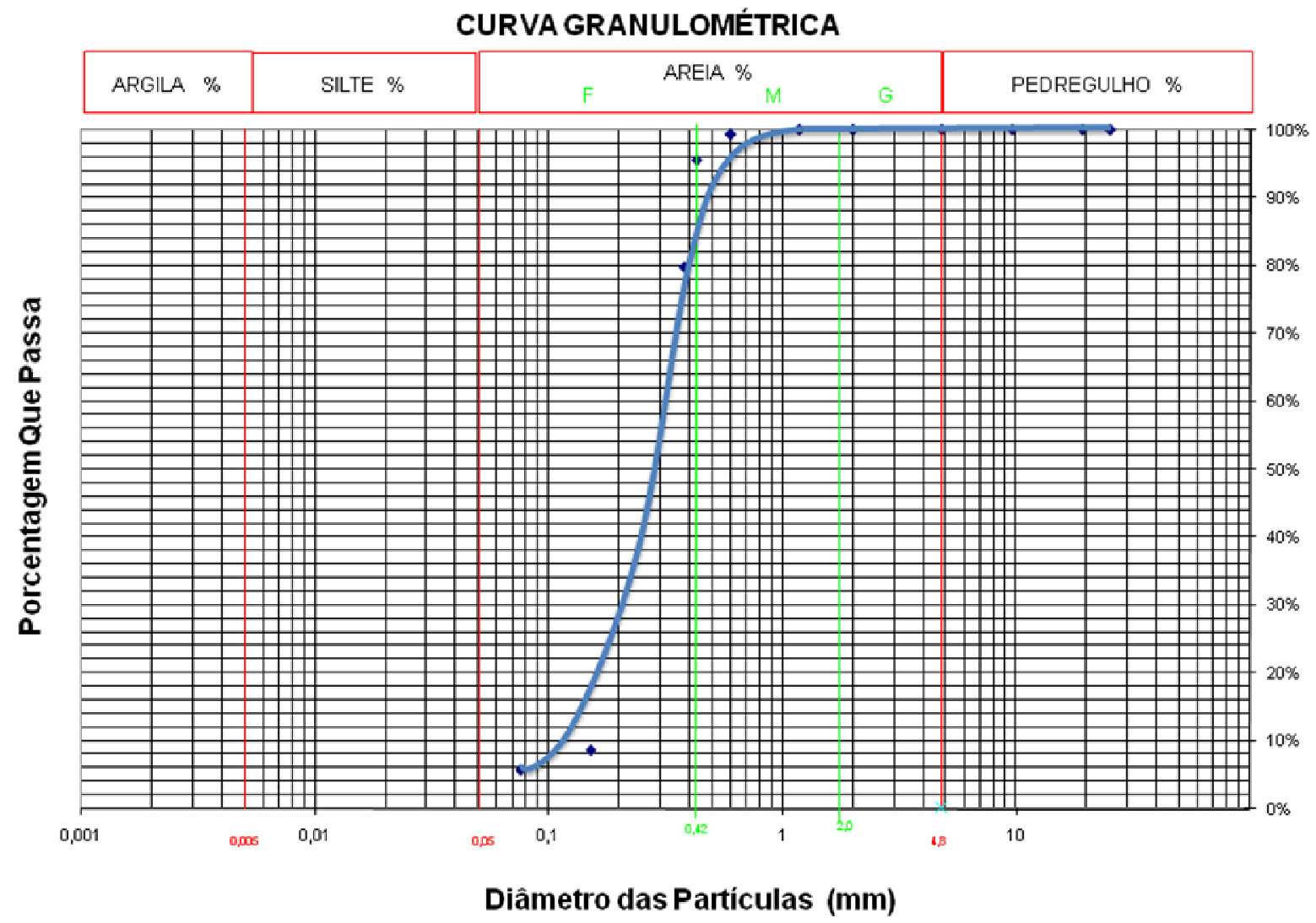

Figura 24 - Curva granulométrica amostra 10D.

Fonte: UFJF - Laboratório de Mecânica dos Solos I.

Notas: Faixa de argila $0,001-0,005 \mathrm{~mm}$; silte $0,005-0,05 \mathrm{~mm}$; areia fina $0,05-0,42 \mathrm{~mm}$; areia média $0,42-2,0 \mathrm{~mm}$; areia grossa 2,0-4,8 $\mathrm{mm}$ e pedregulho $>4,8 \mathrm{~mm}$. 
Tabela 9 - Análise Granulométrica amostra 10M

\begin{tabular}{c|c|c|c|c}
\hline \% Argila e Silte & \% Areia Fina & \% Areia Média & $\%$ Areia Grossa & $\%$ Pedregulho \\
\hline $9,35 \%$ & $38,35 \%$ & $0,00 \%$ & $21,96 \%$ & $30,34 \%$ \\
\hline
\end{tabular}

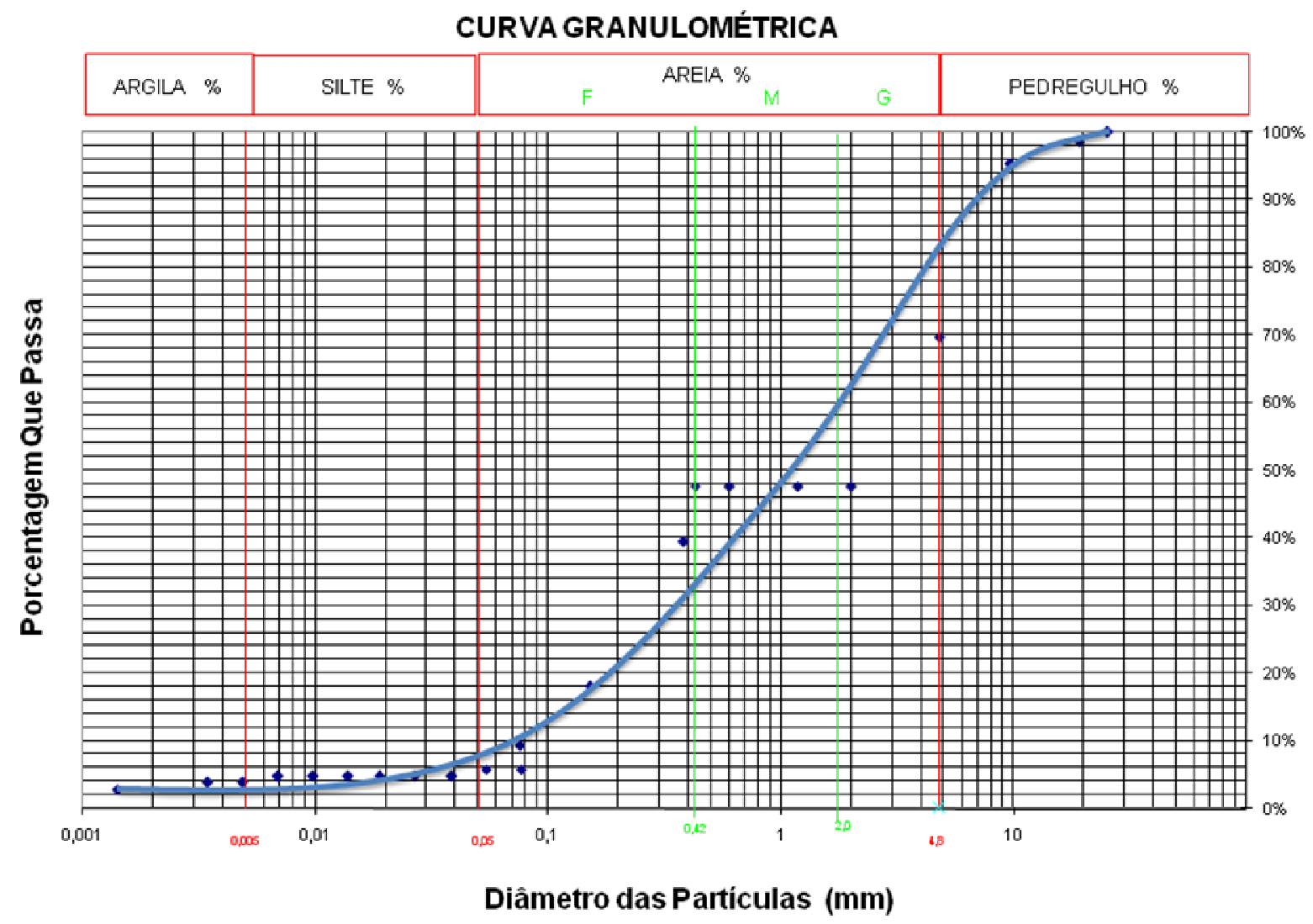

Figura 25 - Curva granulométrica amostra 10M.

Fonte: UFJF - Laboratório de Mecânica dos Solos I.

Notas: Faixa de argila 0,001-0,005 mm; silte 0,005-0,05 mm; areia fina 0,05-0,42 mm; areia média $0,42-2,0 \mathrm{~mm}$; areia grossa $2,0-4,8 \mathrm{~mm}$ e pedregulho $>4,8 \mathrm{~mm}$. 
Tabela 10 - Análise Granulométrica amostra 11D

\begin{tabular}{c|c|c|c|c}
\hline$\%$ Argila e Silte & $\%$ Areia Fina & \% Areia Média & \% Areia Grossa & $\%$ Pedregulho \\
\hline $20,16 \%$ & $78,57 \%$ & $1,27 \%$ & $0,00 \%$ & $0,00 \%$ \\
\hline
\end{tabular}

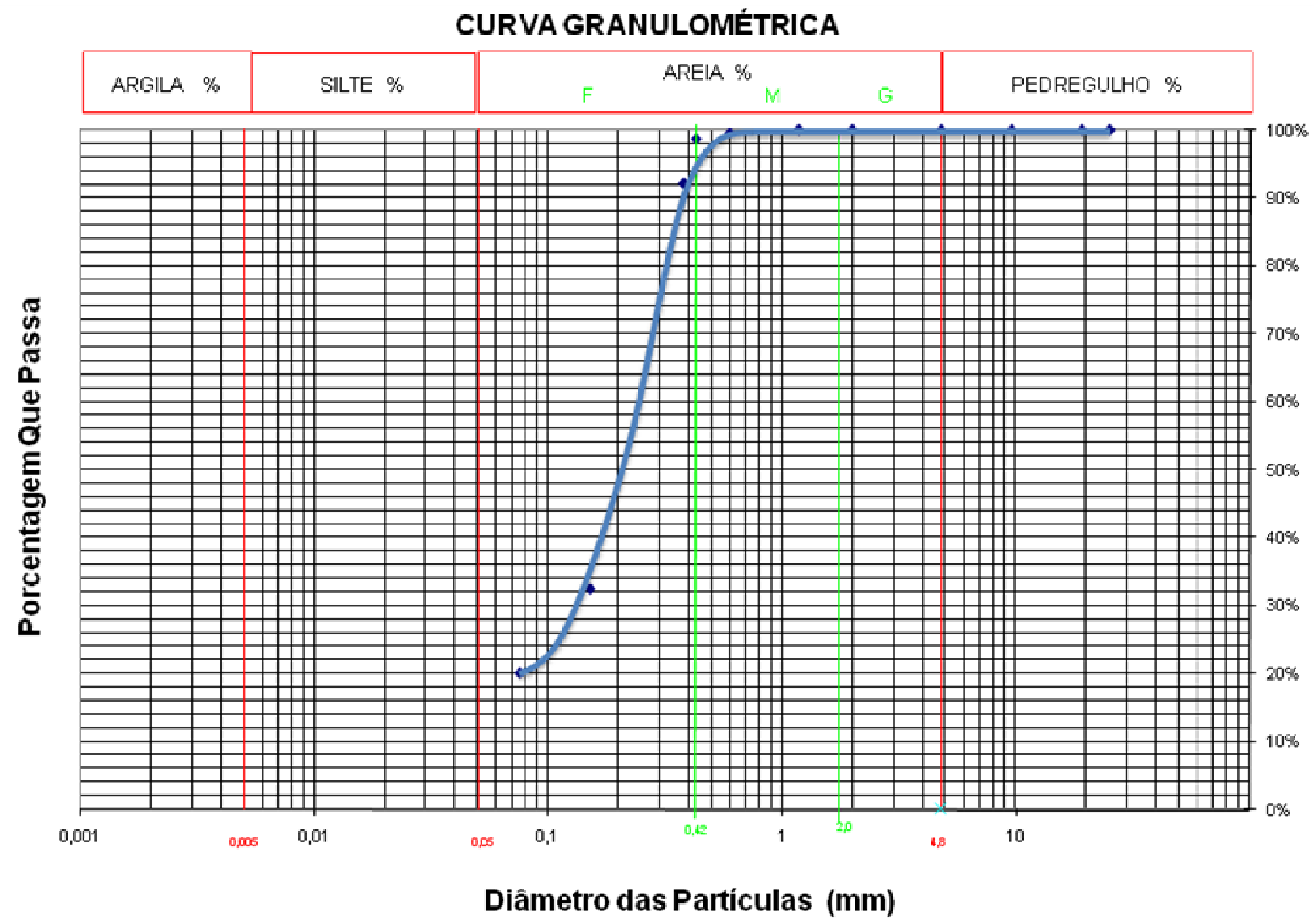

Figura 26 - Curva granulométrica amostra 11D.

Fonte: UFJF - Laboratório de Mecânica dos Solos I.

Notas: Faixa de argila $0,001-0,005 \mathrm{~mm}$; silte $0,005-0,05 \mathrm{~mm}$; areia fina $0,05-0,42 \mathrm{~mm}$; areia média $0,42-2,0 \mathrm{~mm}$; areia grossa $2,0-4,8 \mathrm{~mm}$ e pedregulho $>4,8 \mathrm{~mm}$. 
Tabela 11 - Análise Granulométrica amostra 11M

\begin{tabular}{c|c|c|c|c}
\hline$\%$ Argila e Silte & $\%$ Areia Fina & $\%$ Areia Média & $\%$ Areia Grossa & $\%$ Pedregulho \\
\hline $16,05 \%$ & $60,99 \%$ & $22,96 \%$ & $0,00 \%$ & $0,00 \%$ \\
\hline
\end{tabular}

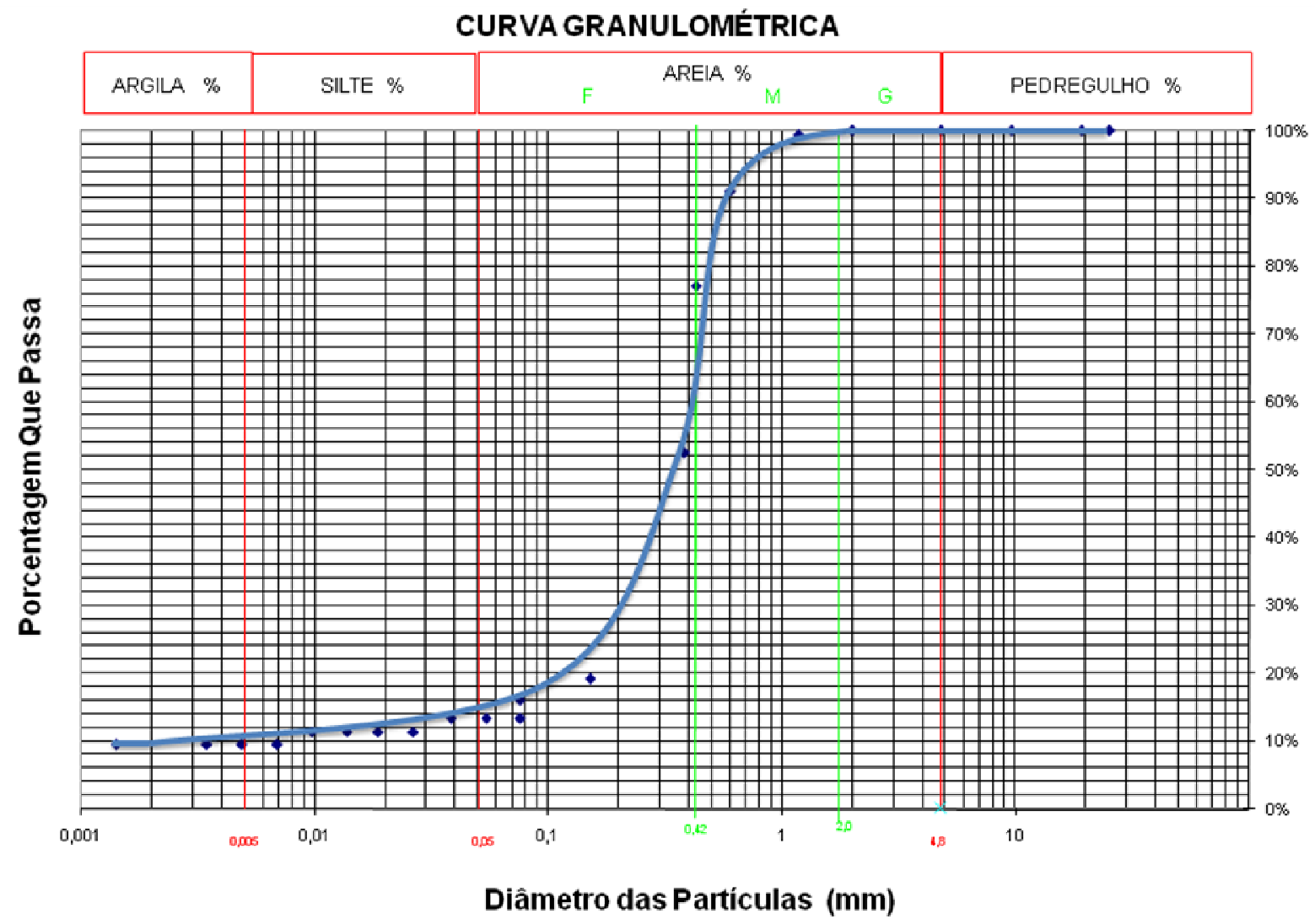

Figura 27 - Curva granulométrica amostra $11 \mathrm{M}$.

Fonte: UFJF - Laboratório de Mecânica dos Solos I.

Notas: Faixa de argila $0,001-0,005 \mathrm{~mm}$; silte $0,005-0,05 \mathrm{~mm}$; areia fina $0,05-0,42 \mathrm{~mm}$; areia média $0,42-2,0 \mathrm{~mm}$; areia grossa $2,0-4,8 \mathrm{~mm}$ e pedregulho $>4,8 \mathrm{~mm}$. 
Tabela 12 - Análise Granulométrica amostra 11E

\begin{tabular}{c|c|c|c|c}
\hline$\%$ Argila e Silte & $\%$ Areia Fina & \% Areia Média & $\%$ Areia Grossa & $\%$ Pedregulho \\
\hline $2,93 \%$ & $15,05 \%$ & $25,86 \%$ & $14,91 \%$ & $41,26 \%$ \\
\hline
\end{tabular}

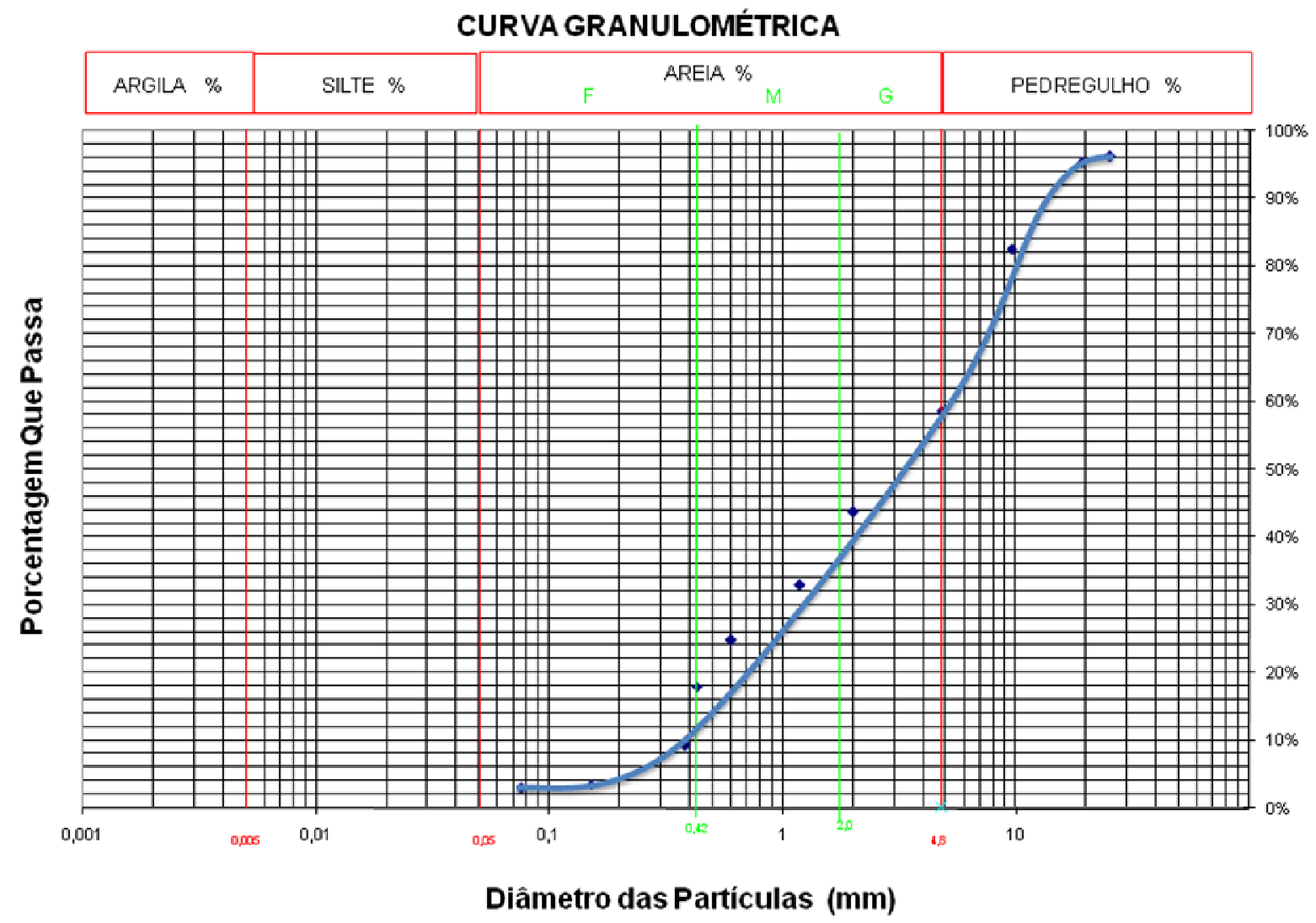

Figura 28 - Curva granulométrica amostra 11E.

Fonte: UFJF - Laboratório de Mecânica dos Solos I.

Notas: Faixa de argila 0,001-0,005 mm; silte 0,005-0,05 mm; areia fina 0,05-0,42 mm; areia média $0,42-2,0 \mathrm{~mm}$; areia grossa $2,0-4,8 \mathrm{~mm}$ e pedregulho $>4,8 \mathrm{~mm}$.

Desta forma através das figuras e tabelas analisadas e literatura consultada observou-se que a caracterização granulométrica está situada entre areia média $(0,42 \mathrm{~mm}-2,0 \mathrm{~mm})$ à areia fina $(0,05 \mathrm{~mm}-0,42 \mathrm{~mm})$.

Segundo a NBR 7211/09 que especifica os requisitos exigíveis para a recepção e produção dos agregados miúdos e graúdos destinados à produção de concretos. A análise granulométrica geral indica que se pode esperar uma grande variação granulométrica na fase do empreendimento e inclusive com a extração de finos, que nem sempre poderão ter aceitação regular em obras comuns. 


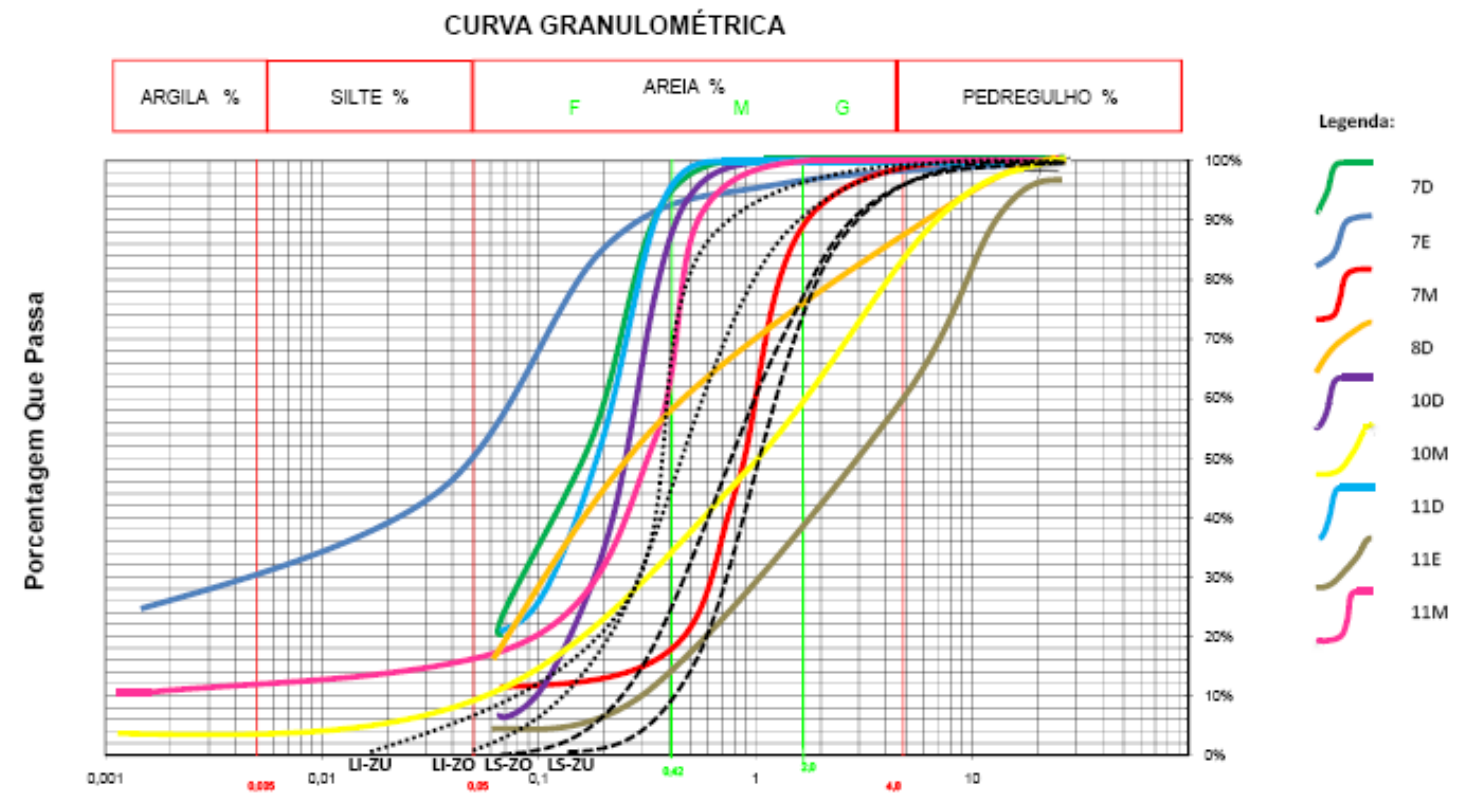

Diâmetro das Partículas (mm)

Figura 29 - Comparação das curvas granulométricas.

Notas: LI-ZU Limite inferior zona utilizável; LI-ZO Limite inferior zona ótima; LS-ZO Limite superior zona ótima; LS-ZU Limite superior zona utilizável.

Faixas da NBR 7211/2009

Pela observação da Figura 29 é possível comprovar que a areia não se enquadra nos limites normalizados. Analisando as quantidades retidas em cada peneira da série, observa-se que quando o objetivo é a busca de uma granulometria contínua, tomando-se por base a média entre os limites da NBR 7211/09, a areia obtida não esta plenamente conforme com a norma.

A Tabela 13 a seguir apresenta a distribuição granulométrica de material retido nas peneiras. 
Tabela 13 - Distribuição granulométrica do agregado miúdo

\begin{tabular}{c|ccccccccc}
\hline Peneiras & \multicolumn{7}{|c}{$\%$ Retida Acumulada Média, em Massa das Amostras } \\
ABNT & 7D & $7 \mathrm{E}$ & $7 \mathrm{M}$ & 8D & 10D & $10 \mathrm{M}$ & $11 \mathrm{D}$ & $11 \mathrm{E}$ & $11 \mathrm{M}$ \\
\hline 9,5 & $0,0 \%$ & $0,0 \%$ & $0,0 \%$ & $9,3 \%$ & $0,0 \%$ & $4,6 \%$ & $0,0 \%$ & $17,5 \%$ & $0,0 \%$ \\
4,8 & $0,0 \%$ & $0,6 \%$ & $0,4 \%$ & $19,2 \%$ & $0,0 \%$ & $30,3 \%$ & $0,0 \%$ & $41,3 \%$ & $0,0 \%$ \\
2,4 & $0,0 \%$ & $1,9 \%$ & $7,6 \%$ & $22,5 \%$ & $0,0 \%$ & $52,3 \%$ & $0,0 \%$ & $56,2 \%$ & $0,0 \%$ \\
1,2 & $0,0 \%$ & $3,2 \%$ & $34,2 \%$ & $25,3 \%$ & $0,0 \%$ & $52,3 \%$ & $0,0 \%$ & $67,1 \%$ & $0,6 \%$ \\
0,6 & $0,5 \%$ & $4,4 \%$ & $75,4 \%$ & $30,9 \%$ & $0,6 \%$ & $52,3 \%$ & $0,2 \%$ & $75,2 \%$ & $8,8 \%$ \\
0,3 & $7,3 \%$ & $6,0 \%$ & $85,9 \%$ & $44,9 \%$ & $20,3 \%$ & $60,4 \%$ & $7,8 \%$ & $90,7 \%$ & $47,5 \%$ \\
0,15 & $58,2 \%$ & $10,9 \%$ & $88,8 \%$ & $82,3 \%$ & $91,3 \%$ & $81,9 \%$ & $67,5 \%$ & $96,4 \%$ & $80,8 \%$ \\
Fundo & $0,0 \%$ & $0,0 \%$ & $0,0 \%$ & $0,0 \%$ & $0,0 \%$ & $0,0 \%$ & $0,0 \%$ & $0,0 \%$ & $0,0 \%$ \\
DMC & 0,6 & 0,6 & 4,8 & 9,5 & 0,6 & 4,8 & 0,6 & 9,5 & 1,2 \\
MF & 0,66 & 0,27 & 2,92 & 2,34 & 1,12 & 3,34 & 0,76 & 4,44 & 1,38 \\
\hline
\end{tabular}

Notas: DMC dimensão máxima característica, MF módulo de finura.

Considerando-se os valores obtidos, há um excesso de material retido nas peneiras $0,6 \mathrm{~mm}, 1,2 \mathrm{~mm}, 4,8 \mathrm{~mm}$ e $9,5 \mathrm{~mm}$, e desta forma a classificação granulométrica da areia não se enquadra aos limites prescritos pela NBR 7211/09 devido a esta variação nas zonas utilizáveis para os limites inferiores e superiores representados pelos módulos de finuras entre areia fina a agregado graúdo. Para apresentar granulometria contínua e melhoria na qualidade para a aplicação em concreto será eventualmente necessário correção no processo produtivo. 


\subsubsection{Teor de Impurezas Orgânicas}

A quantidade de impurezas orgânicas foi analisada em três das amostras de areia $(7 \mathrm{M}, 10 \mathrm{D}$ e $11 \mathrm{M})$ coletadas na área delimitada da obra de desassoreamento.

Segundo a NBR NM 49/01, as três amostras apresentam soluções com uma coloração mais escura comparada com a cor da solução padrão, conforme Figura 30.

Desta forma, os resultados obtidos não atende ao limite citado e prescrito pela NBR 7211/09. Em vista disto, a utilização destas areias em concretos deve estar ainda sujeita a ensaio complementar de qualidade, para avaliação dos seus efeitos sobre o desenvolvimento da hidratação e resistência mecânica do concreto.

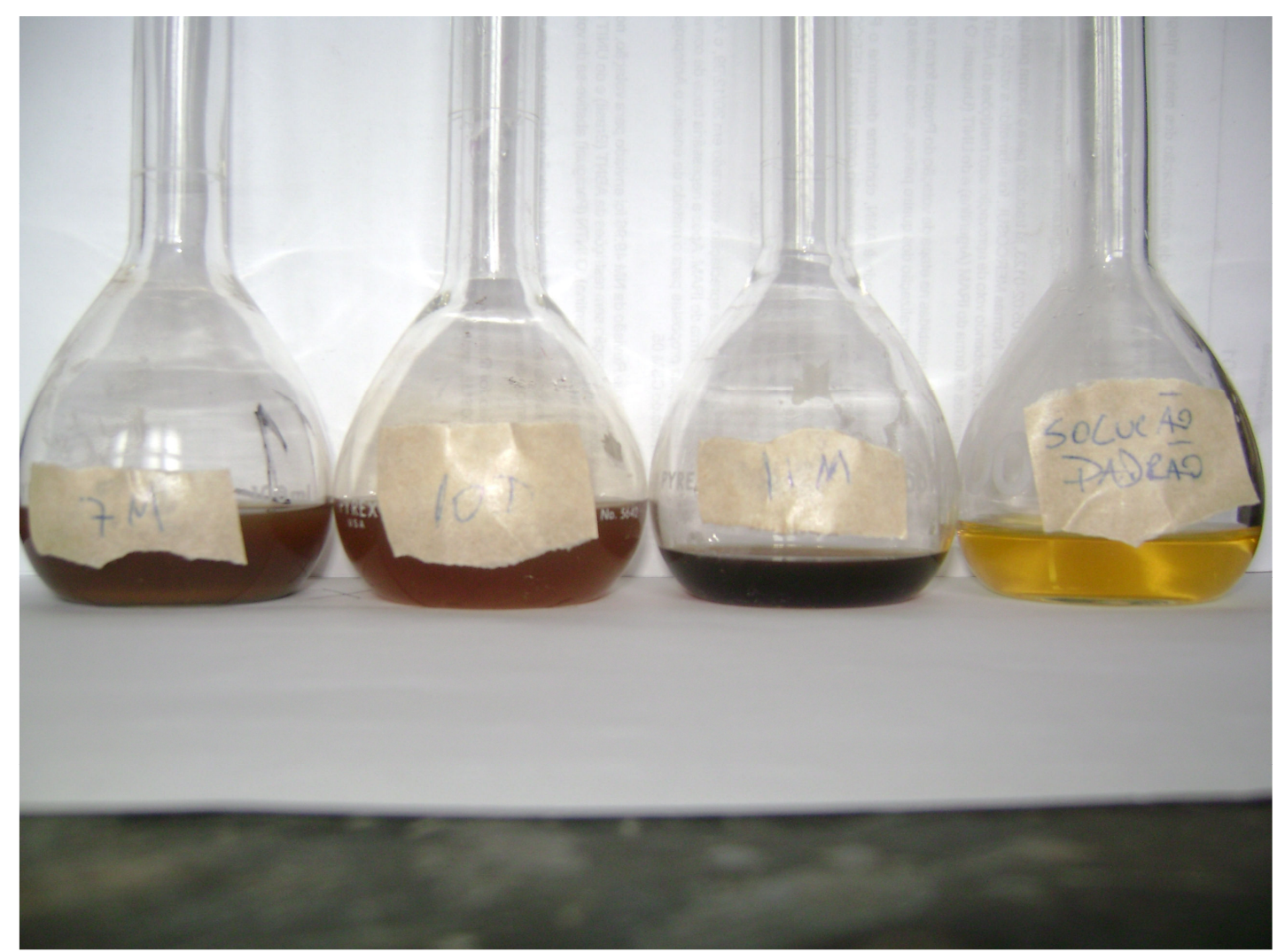

Figura 30 - Resultados do ensaio de impurezas orgânicas. (30/09/09) 


\subsubsection{Análise Química - Fluorescência de Raios X}

A Tabela 14 apresenta os resultados obtidos na análise química quantitativa, por espectrometria de fluorescência de raios $\mathrm{X}$.

Tabela 14 - Resultados quantitativos de composição química pela fluorescência de raios $X$ para a amostra $10 D$

Resultados em \%

\begin{tabular}{|l|l|c|c|c|c|c|c|c|c|c|c|c|}
\hline $\mathrm{N}^{\circ} \mathrm{LCT}$ & Amostra & $\mathrm{SiO}_{2}$ & $\mathrm{Al}_{2} \mathrm{O}_{3}$ & $\mathrm{Fe}_{2} \mathrm{O}_{3}$ & $\mathrm{MnO}$ & $\mathrm{MgO}$ & $\mathrm{CaO}$ & $\mathrm{Na}_{2} \mathrm{O}$ & $\mathrm{K}_{2} \mathrm{O}$ & $\mathrm{TiO}_{2}$ & $\mathrm{P}_{2} \mathrm{O}_{5}$ & $\mathrm{PF}$ \\
\hline $8757 / 09$ & $7 \mathrm{M}$ & 91,6 & 4,08 & 0,88 & $<0,10$ & $<0,10$ & $<0,10$ & 0,17 & 1,49 & 0,16 & $<0,10$ & 1,32 \\
\hline $8758 / 09$ & $10 \mathrm{D}$ & 90,2 & 4,26 & 1,33 & $<0,10$ & 0,12 & 0,26 & 0,31 & 1,26 & 0,66 & $<0,10$ & 0,87 \\
\hline $8759 / 09$ & $11 \mathrm{M}$ & 83,4 & 8,68 & 2,33 & 0,10 & 0,15 & 0,15 & 0,23 & 1,49 & 0,57 & $<0,10$ & 3,27 \\
\hline
\end{tabular}

Fonte: Laboratório de Caracterização Tecnológica do Dep. de Engenharia de Minas e de Petróleo. Certificado: 1034-09 (Resultados das Análises Químicas).

\subsubsection{Composição Mineralógica - Difração de Raios X}

Com o objetivo de conhecer a composição mineralógica de uma das amostras coletadas no sedimento do leito do rio foi feita análises de difração de raios $\mathrm{X}$. A Tabela 15 apresenta os resultados da difratometria de raios $\mathrm{X}$.

Tabela 15 - Resultados da Difratometria de raios X para a amostra 10D

\begin{tabular}{cllll}
\hline ICDD & Nome do Composto & Fórmula Química & Mineral & Obs \\
\hline 01-089-8935 & Quartzo & $\mathrm{SiO}_{2}$ & Quartzo & \\
01-088-1175 & Rutilo & $\mathrm{TiO}_{2}$ & Rutilo & \\
01-075-0948 & Muscovita & $\mathrm{KAl}_{3} \mathrm{Si}_{3} \mathrm{O}_{10}(\mathrm{OH})_{2}$ & Muscovita & \\
01-076-1239 & Microclínio & ${\mathrm{K}\left(\mathrm{Si}_{3} \mathrm{Al}\right) \mathrm{O}_{8}}$ & Microclínio & \\
01-076-0927 & Albita & $\left(\mathrm{Na}_{0,84} \mathrm{Ca}_{0,16}\right) \mathrm{Al}_{1,16} \mathrm{Si}_{2,84} \mathrm{O}_{8}$ & Albita & \\
$00-017-0536$ & Goethita & $\mathrm{Fe}^{+3} \mathrm{O}(\mathrm{OH})$ & Goethita & pp \\
\hline
\end{tabular}

Nota: $p p=$ possível presença

Fonte: Laboratório de Caracterização Tecnológica do Dep. Engenharia de Minas e de Petróleo. Certificado: 469-09 (Resultados da Difratometria de raios X).

A Figura 31 apresenta o difratograma da areia proveniente de leito de rio. Sua análise indica a presença predominante de sílica na forma de quartzo. As fases identificadas neste difratograma podem ser observadas na Figura 32, pelos correspondentes picos de quartzo, rutilo, muscovita, microclínio, albita e a possível presença de goethita. 


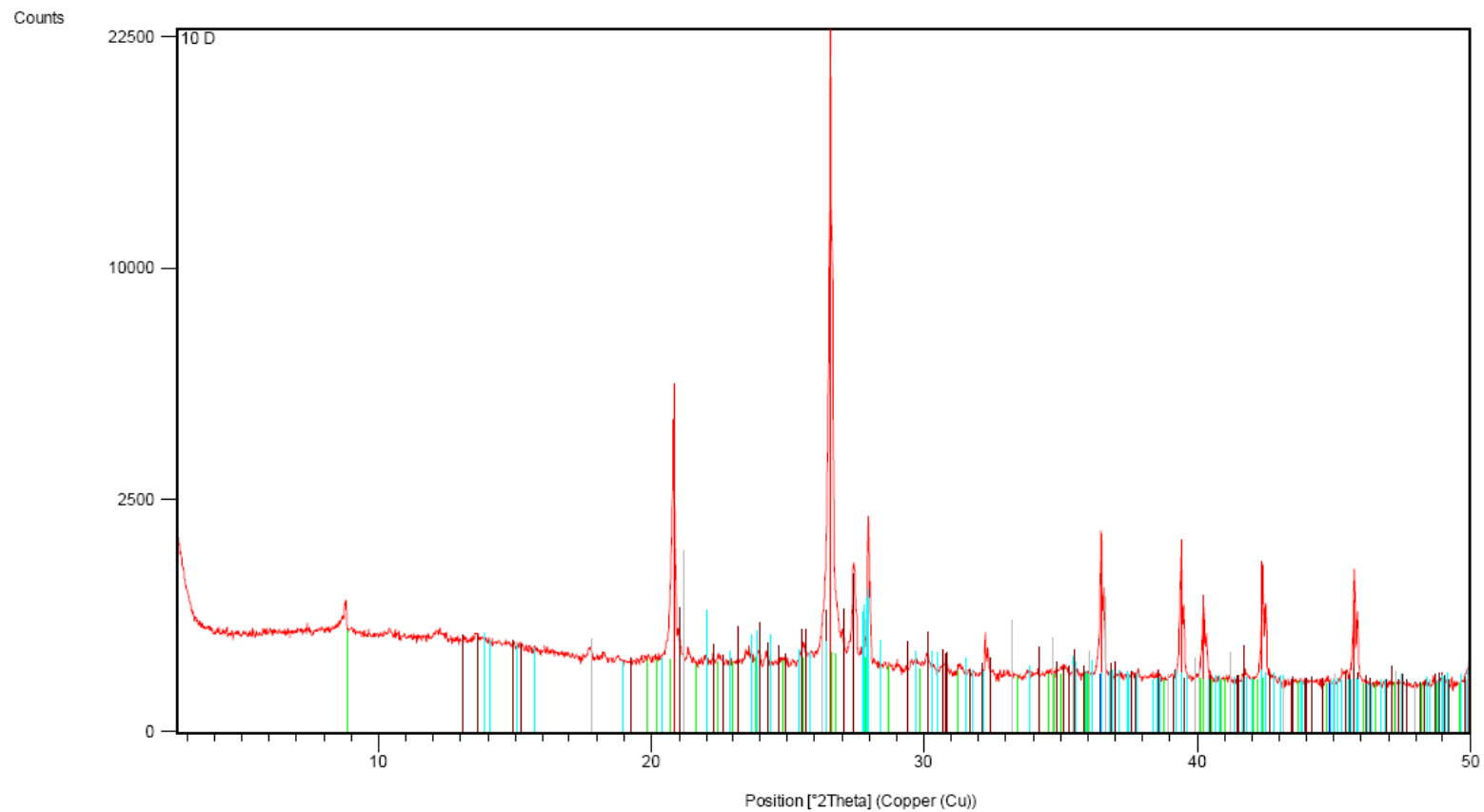

Figura 31 - Difratograma de Raios X da amostra 10D.

Fonte: Laboratório de Caracterização Tecnológica do Dep. Engenharia de Minas e de Petróleo. Certificado: 469-09 (Resultados da Difratometria de raios X).

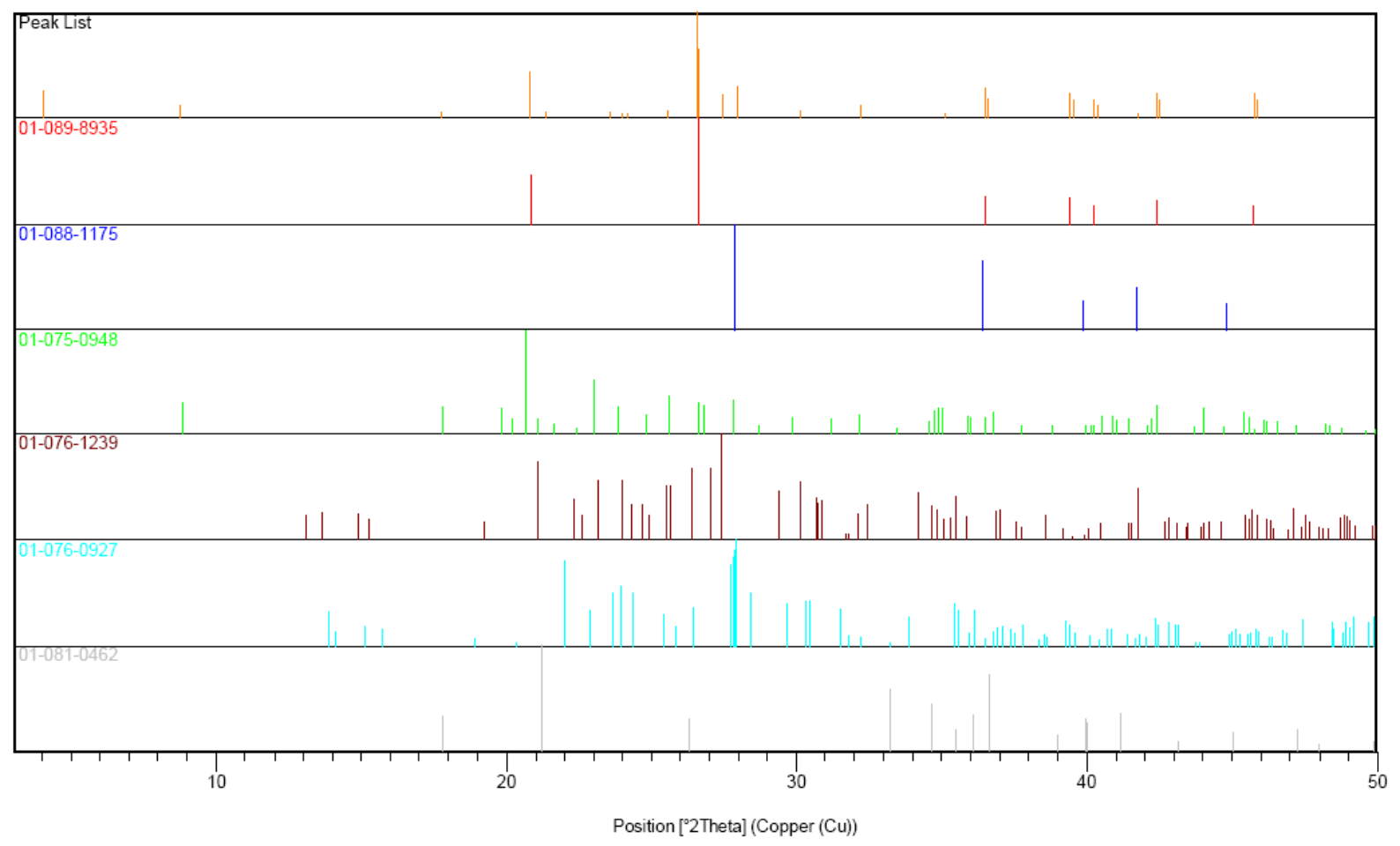

Figura 32 - Fases identificadas no difratograma de Raios X da amostra 10D.

Fonte: Laboratório de Caracterização Tecnológica do Dep. Engenharia de Minas e de Petróleo.

Certificado: 469-09 (Resultados da Difratometria de raios X). 


\subsection{Projeto Conceitual}

O Projeto Conceitual é um roteiro técnico de estudos e análises das diversas fases do empreendimento e dos diversos meios que poderão ser alterados pela implantação do empreendimento e visam fornecer uma estrutura do que poderá ser a instalação industrial.

Para obtenção do direito de lavra, devem ser cumpridos alguns procedimentos específicos nas entidades que detêm as competências no contexto das legislações mineral e ambiental, respectivamente, o Departamento Nacional da Produção Mineral (DNPM) e a Secretaria do Meio Ambiente/SP (SMA). Os procedimentos para o processo de requerimento e obtenção de títulos minerários estão, no caso do Estado de São Paulo, articulados com os procedimentos para o licenciamento ambiental das atividades de mineração.

A fase de licenciamento exige o desenvolvimento e apresentação de planos e projetos referentes à implantação, operação e encerramento da atividade, como descritos a seguir.

\subsubsection{Fase de Implantação}

Após obtida a Licença de Implantação, serão iniciadas as atividades de instalação dos equipamentos e preparação da área e medidas mitigadoras, como cercamentos e preparação de acessos.

\subsubsection{Fase de Operação}

Alvo da obra de desassoreamento, a lavra no leito do rio será realizada pelo sistema de dragagem, por meio de um conjunto moto-bomba instalado sobre uma barcaça auto-dragante, o qual succiona o material depositado no leito do rio, enviando o material dragado (areia + restos vegetais e eventualmente cascalhos) através de uma tubulação até o classificador de dupla granulometria, onde também serão segregados os restos vegetais e cascalhos dragados, ficando estes resíduos amontoados ao pé do classificador, até serem removidos. Este trecho será delimitado por pares de bóias flutuantes, para a preservação das margens do rio e para sinalização das atividades de desassoreamento. 
A seguir são descritas as etapas de operações durante a extração mineral no local.

O beneficiamento inclui várias etapas para a separação por tamanhos que, de uma forma geral, consiste na separação de partículas com base nas dimensões físicas das mesmas, dando início à operação do empreendimento.

\section{Peneiramento}

O peneiramento é um processo mecânico de separação de partículas que se utiliza de peneiras com malhas de aberturas definidas. As partículas com dimensões superiores à da abertura considerada ficam retidas na superfície e as com dimensões inferiores tendem a atravessar a mesma. Os mecanismos envolvidos compreendem basicamente estratificação, transporte e segregação. Os equipamentos tradicionalmente utilizados são as peneiras vibratórias, rotativas e estáticas.

Neste processo, o cascalho é retido e redirecionado como sub-produto para comercialização ou revitalização de vias de acesso.

\section{Classificação}

A classificação é o processo de separação que se baseia na velocidade de sedimentação das partículas se deslocando em um fluido viscoso. O transporte das partículas é feito geralmente na forma de uma suspensão aquosa denominada polpa.

Para esta etapa um classificador será utilizado para segregação do material em pilhas no pátio de beneficiamento.

\section{Desaguamento}

A água desempenha um papel expressivo no tratamento de minérios. No entanto, numa determinada etapa do processo se faz necessária sua retirada para poder se obter produtos com baixa umidade.

\section{Secagem}

A secagem consiste na retirada da água contida num produto sólido particulado através da vaporização da mesma por ação do calor. Este processo 
ocorre concomitantemente à classificação e desague do concentrado para obtenção do produto final.

Em muitos casos a secagem não é necessária e para a areia poucas aplicações demandam esta operação bastante dispendiosa.

\section{Bacia de Contenção}

Dentro do processo de extração por via úmida o rejeito contendo finos (silte, argila e areia fina) é destinado à bacia de contenção para a decantação.

A disposição de rejeitos provenientes do processo de beneficiamento localiza-se ao lado da classificação no pátio, onde o sistema para a decantação e clarificação da polpa fica restrito ao tempo de depuração antes do retorno destas águas ao curso hídrico ou recirculação desta no processo.

\section{$>$ Manuseio de Materiais}

O transporte e estocagem de materiais constituem uma das mais importantes operações em qualquer unidade de tratamento de minérios. $O$ transporte é requerido entre cada etapa do processo e frequentemente como parte do mesmo. Áreas de estocagem também são necessárias antes, durante e depois do beneficiamento e na indústria de areia é denominado pátio de manobras. $O$ manuseio de materiais abrange não só produtos sólidos, enxutos ou secos como também suspensões aquosas das partículas minerais.

\section{Caracterização Tecnológica}

Esta etapa visa determinar a composição e demais características físico, química e tecnológica do material em estudo, inicialmente serão executadas a formação de lote de agregado com as quantidades predeterminadas do material produzido, armazenado ou transportado sob condições presumidamente uniformes. Posteriormente serão executados estudos para a determinação do balanço de massa definindo assim seu melhor aproveitamento para o concentrado, cascalho e finos.

A Figura 33 mostra o fluxograma proposto das fases descritas anteriormente da dragagem do Rio Paraibuna. 
Fluxograma de Dragagem no leito do rio

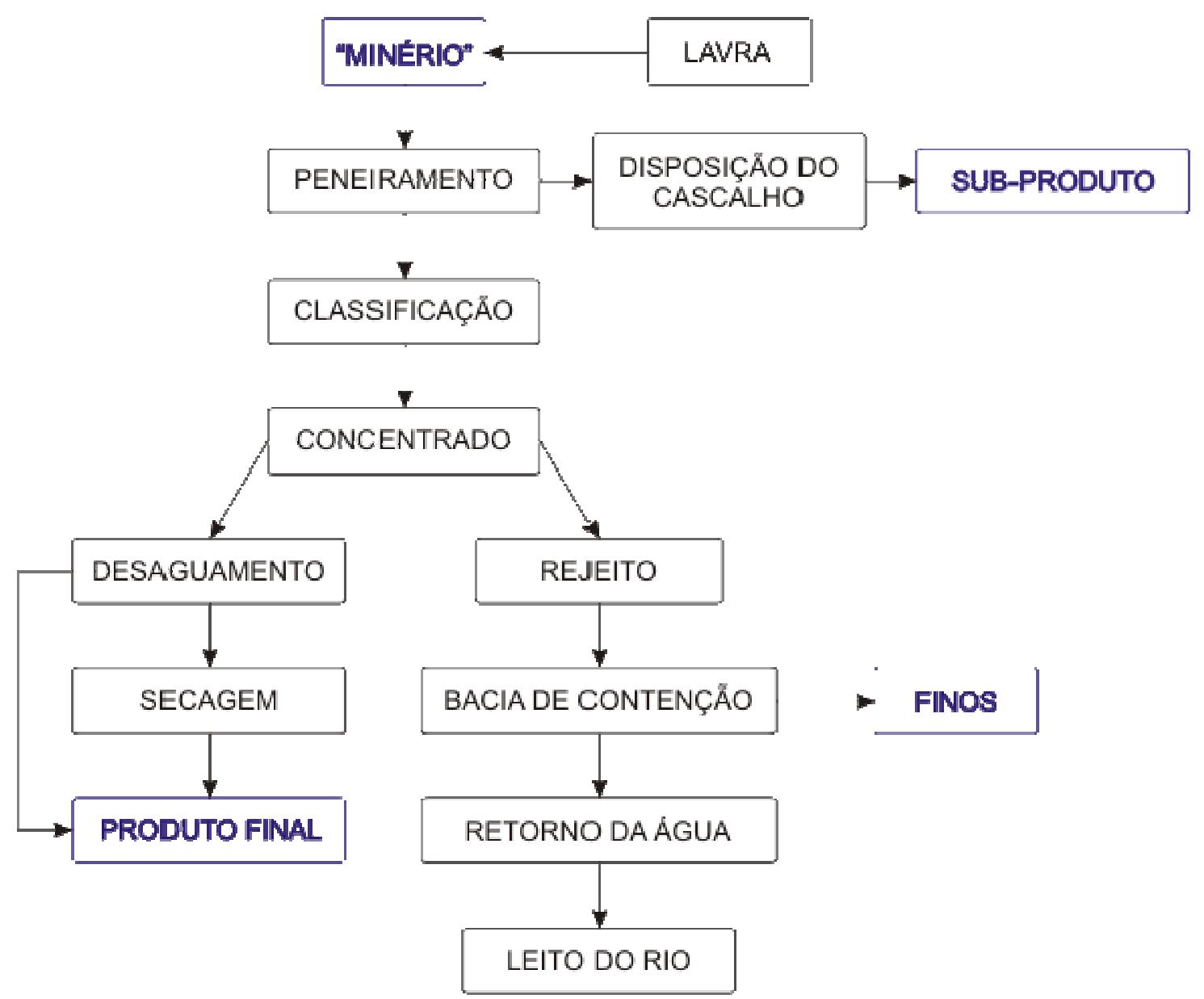

Figura 33 - Fluxograma conceitual da dragagem no leito do Rio Paraibuna.

\subsubsection{Estimativa do Balaço de Massa Preliminar}

Com as informações obtidas na determinação do volume de areia analisados com os resultados das curvas granulométricas e tabelas de porcentagem foi obtido o seguinte balanço de massa, que é usado para se avaliar quantitativamente os processos de concentração e operação do projeto conceitual.

A Figura 34 ilustra o volume considerado para cada operação do empreendimento considerando a eficiência estimada de cada processo. 


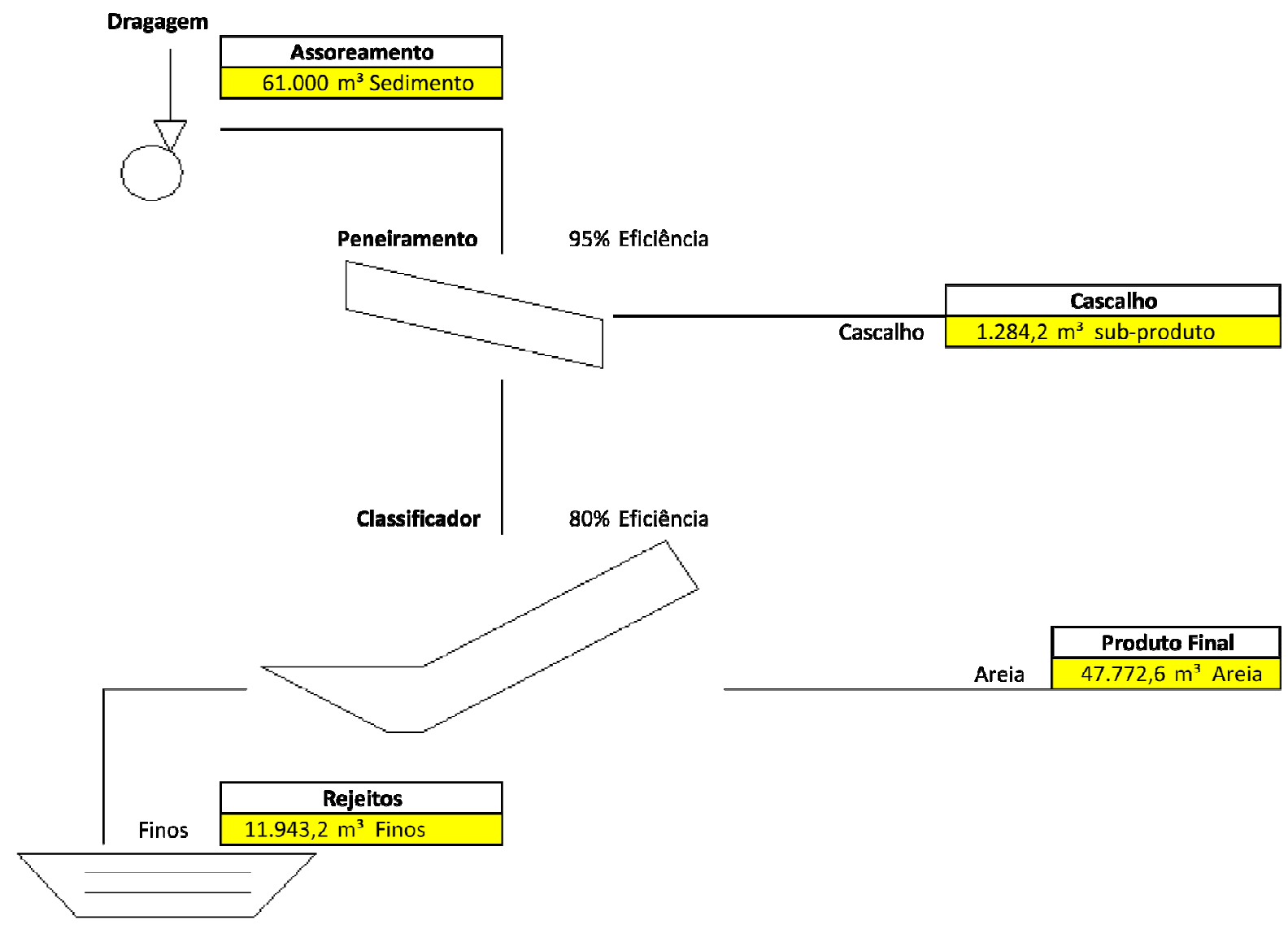

Bacia de Contenção

Figura 34 - Fluxograma da Estimativa do Balaço de Massa Preliminar.

A partir deste balanço a nova receita gerada para o projeto conceitual é de um milhão e duzentos mil reais aproximadamente, considerando o custo de $\mathrm{R} \$$ 25,00 para a tonelada de areia e $R \$ 5,00$ a de cascalho. Desta forma com a execução da obra de desassoreamento de 14 meses, a receita mensal será de cerca de oitenta e cinco mil reais.

\subsubsection{Medidas Mitigadoras}

Os principais impactos que eventualmente poderiam ser observados na área estão descritos a seguir, porém todos são de pequena expressividade, frente às medidas de controle propostas para o empreendimento.

Como itens de baixo impacto pode-se mencionar:

\section{Degradação da Paisagem e Alteração da Fauna}

Esta degradação se relaciona à alteração provocada pela extração de minério do local. Em relação à degradação da paisagem, este impacto negativo 
deverá ser totalmente eliminado com o encerramento das atividades, visto que haverá a remoção completa dos estoques de areia e dos equipamentos das áreas ocupadas pelos pátios. A fauna local, por ser pequena, quase não deverá ser atingida por este impacto.

\section{> Comprometimento do Uso da Superfície}

Trata-se de uma alteração ambiental inevitável e inerente ao tipo de atividade que se desenvolverá no local, pois envolve a utilização de caixas fixas, maquinários e de pequenas pilhas de minério.

No entanto, atualmente, a área apresenta baixa utilização antrópica, e o pátio a ser utilizado já se encontra desprovido de vegetação.

Com o final das atividades extrativas, todos os maquinários, equipamentos e pilhas de materiais serão removidos, sendo a área do pátio recuperada, trazendo ao local um perfil ecológico mais equilibrado. Como a extração ocorrerá somente no leito do rio, não se formará no local nenhuma nova cava, o que resultaria num impacto irreversível à área pela inviabilidade de aterramento das mesmas.

\section{Alterações na Dinâmica Fluvial e Nível d'Água}

A extração no leito do rio foi planejada de forma a se remover os sedimentos depositados nos últimos anos em seu curso em trecho próximo ao pátio. Este posicionamento dos trechos foi selecionado de modo a permitir que se mantivesse certa proximidade do pátio.

Desta forma, cada trecho depois de extraído funcionará como um receptor de sedimentos, evitando com isto uma sedimentação progressiva no leito do rio e consequentemente que o mesmo extravase de seu leito e provoque enchentes, ao mesmo tempo em que praticamente não alterará a nível d'água atual e a dinâmica fluvial existente.

E como itens a receberem medidas de controle ou mitigadoras pode-se mencionar:

\section{Ruído}

As principais fontes de ruídos são decorrentes da operação da draga, máquinas e caminhões transportadores do bem mineral, deixando de ocorrer com o término das atividades extrativas. 
A área de influência deste impacto confina-se principalmente ao local de extração. Desta forma, esta alteração atingirá os funcionários do empreendimento, mais especificamente os operadores das máquinas. Trata-se então de um impacto reversível e de pequena magnitude.

As medidas mitigadoras indicadas para diminuir os efeitos deste impacto são:

- uso de silenciadores nas máquinas e adequada manutenção das mesmas;

- uso de protetores auriculares pelos operadores das máquinas;

- realização de exames audiométricos periódicos nos operadores das máquinas; e

- operação da lavra somente nos horários estabelecidos pela Prefeitura Municipal e/ou órgão ambiental responsável.

\section{$>$ Poeira}

Esta alteração ambiental tem origem no arraste eólico do material depositado nas pilhas de material extraído, além do tráfego de caminhões nas vias de acesso não pavimentadas e da operação das máquinas no pátio de manobras do empreendimento. A área de influência deste impacto está praticamente restrita à área de apoio do empreendimento.

Como medidas mitigadoras para este impacto, principalmente nos períodos de estiagem, devem ser adotadas as seguintes:

- aspersão de água nas pilhas de materiais, na via de acesso interna ao empreendimento e nos pátios de manobra nos períodos mais secos do ano;

- utilização de equipamentos de proteção individual pelos funcionários; e

- cobertura das carretas transportadoras com lona quando for necessário.

Este impacto, como o anterior, possui efeito temporário, visto que com o término da explotação pelo empreendimento, o trânsito de máquinas e veículos transportadores do bem mineral deixará de ocorrer.

\section{Poluição Química das Águas por Óleos e Graxas}

Este impacto pode originar-se durante todo o processo de extração pelo possível derramamento de óleos e graxas no solo e na água do rio, quando da utilização do maquinário. 
Visando atenuar a contaminação no local, o combustível utilizado nos motores dos equipamentos deverá ser transportado em galões, de acordo com a necessidade de abastecimento, da mesma maneira que ocorre nas áreas já licenciadas no entorno.

Periodicamente deverá ser realizada a revisão dos equipamentos utilizados pelo empreendimento, de modo a evitar e prevenir eventuais vazamentos de óleo e/ou combustíveis. Além disto a manutenção dos equipamentos rodantes deverá ser feito fora da área de produção em oficinas especializadas.

\section{Poluição Física das Águas (Partículas em Suspensão)}

A poluição física das águas por partículas em suspensão não trará grande impacto à área, uma vez que o material fino eventualmente produzido pela lavagem da areia deverá se depositar nas bacias de decantação, não retornando ao rio, nem sendo lançado em qualquer outro curso d'água do entorno, será depositado em aterro. Além disto, pelo fato da extração se desenvolver no leito do rio, a areia apresenta-se com quantidade bem inferior de finos quando comparada com a areia extraída normalmente em terrenos de várzea, possibilitando assim uma menor quantidade de partículas em suspensão.

A técnica efetuada para a disposição temporária será em bacias de decantação, onde após tempo de repouso e clareamento da água a mesma será redirecionada ao rio ou reusada no beneficiamento. Para tanto, nessa disposição faz-se necessária a retirada periódica do depositado por meio de escavação mecânica quando cheias, e o seu transporte final para aterro.

\section{> Poluição Biológica das Águas}

Este impacto poderia ocorrer principalmente pela disposição incorreta dos efluentes sanitários produzidos nas dependências do empreendimento.

A lavagem e lubrificação dos equipamentos deverão ser efetuadas em local propício para tal. A fim de se evitar este impacto, deverão ser utilizadas dependências sanitárias a serem implantadas ao lado do pátio, acopladas a fossas sépticas de acordo com as normas da legislação vigente e o mais distante possível dos cursos d'água. 


\section{$>$ Emissão de Gases}

Este impacto origina-se da combustão do óleo diesel pelos equipamentos usados na extração, tendo influência sobre os funcionários, porém sem grandes prejuízos para a qualidade do ar, visto que os gases terão uma rápida dispersão.

A medida mitigadora para esse impacto relaciona-se ao adequado funcionamento e manutenção dos equipamentos. É um impacto temporário que deixará de ocorrer com o final das atividades extrativas na área.

\section{$>$ Circulação de Veículos}

A areia extraída pelo empreendimento deverá seguir por estradas de terra internas da propriedade até a rodovia local, seguindo diretamente a concreteiras, depósitos de materiais de construção e obras de engenharia civil em diversos pontos da região. Os volumes a serem produzidos não são muito grandes, de forma que não haverá grandes alterações no tráfego da região, que é relativamente intenso em função do desenvolvimento econômico da mesma.

Como forma de minimizar as alterações causadas pela circulação de veículos e assegurar a segurança da população da região deverá ser realizada a orientação dos motoristas dos caminhões transportadores quanto à rota a ser seguida, os horários de fluxo e quanto à forma adequada de transporte dos materiais em relação ao volume, nível de material não excedendo à altura da caçamba e proteção da carga com cobertura de lonas ou similares, quando necessário.

\section{> Produção de Sucatas e Resíduos}

A sucata originária da operação do empreendimento deverá ser armazenada em pilhas temporárias em local preestabelecido, sendo comercializada periodicamente junto a sucateiros da região, enquanto que o resíduo "tipo doméstico", proveniente das instalações de apoio do empreendimento, deverão ser periodicamente remetidos ao aterro sanitário mais próximo. 


\subsubsection{Fase de Encerramento}

Assim como a implantação e operação, o encerramento das atividades de extração e fechamento da mina também requer planejamento e projetos específicos.

A reestruturação é um dos elementos que devem ser objeto de preocupação e de ações efetivas desde os primórdios do processo de planejamento, durante a explotação da jazida e por um longo período após o término das atividades no local.

Neste caso, devido à extração localizar-se no leito do rio, as áreas passíveis de reestruturação são os pátios de manobras, beneficiamento, bacias de contenção, além da desmobilização de construções e tubulações. 


\section{CONSIDERAÇÕES PARA A EXPLOTAÇÃO}

O estudo-de-caso focado por esta dissertação, analisou o elevado assoreamento do Rio Paraibuna, no trecho do município de Paraibuna-SP, e discute a necessidade de seu desassoreamento, em caráter de utilidade pública, para melhoria das condições da captação d'água do município.

\subsection{Conclusões}

No presente estudo-de-caso, o problema de assoreamento terá de ser resolvido por uma obra emergencial, em virtude do risco iminente de paralisação das bombas na ETA, além do desgaste acelerado dos encanamentos, motores, filtros e demais equipamentos de tratamento de águas, uma vez que sofrem constante abrasão das partículas de areia que são sugadas pelas bombas e entram nos encanamentos. Outro aspecto que o torna emergencial é o potencial de causar um grave problema de comprometimento da estrutura da ponte da Rodovia dos Tamoios.

Ambos os problemas serão solucionados através do processo de desassoreamento do local e das áreas adjacentes que contribuem para este acúmulo de material depositado.

Para a obra no trecho assoreado, verificou-se que as técnicas de extração mineral a serem desenvolvidas através da dragagem hidráulica em leito submerso e todo o sistema de beneficiamento, são considerados satisfatórios para atender os aspectos sócio-ambientais e econômicos.

A descrição qualitativa do minério, do ponto de vista mineralógico, auxilia na definição da viabilidade da sua explotação econômica, disponibilizando informações para melhor definição de suas características e aproveitamento.

A composição mineralógica do material sedimentado é constituída de quartzo, rutilo, muscovita, microclínio, albita e possível presença de goethita.

Assim, essa caracterização mineralógica aponta potencial de viabilidade em sua explotação econômica e disponibilizando informações para melhor definição de suas características e aproveitamento.

Ante os fatos apontados neste trabalho e sua pesquisa mineral foi verificado que o material encontrado na área de estudo apresenta uma distribuição 
granulométrica, com predominância de areia de média a fina, o que significa que pode ter boa aceitação no mercado. Entretanto, os teores de matéria orgânicos e finos argilosos elevados implicam na necessidade de eficiência no beneficiamento da areia, para melhor aproveitamento e aumento de sua qualidade, especialmente para aplicações específicas como em concreto estrutural.

Com base na demanda e oferta de areia no Vale do Paraíba, os produtos resultantes desta atividade de extração tem potencial para serem comercializados e distribuídos, uma vez que o mercado ao qual se destina é extremamente promissor.

O projeto conceitual proposto visa maior viabilidade para o material sedimentado dragado, e aumento do rendimento econômico retomando o investimento inicial com o faturamento do empreendedor sendo superado pelo valores mensais e anual. Definindo o aproveitamento aceitável para a areia, cascalho e finos promovidos pelo balanço de massa como estimativa preliminar.

Ainda baseado em estimativas preliminares, o empreendimento mostra-se economicamente viável, com a recuperação do investimento, em curto prazo e, devido à sua execução em área degradada, somado as medidas mitigadoras propostas, considera-se ser de baixo impacto ambiental.

Ressalte-se ainda as características de sustentabilidade e proteção ao meio ambiente decorrentes do aproveitamento de um material que precisa ser removido e se não for aproveitado, causará os impactos decorrentes de sua disposição, além de contaminação de águas, assoreamento de canais ou cursos d'água, devido ao seu arraste pelas chuvas, poeiras e a ocupação desnecessária de espaço físico entre outros.

Baseado no Zoneamento Minerário (SMA,1999), observou-se que após a vigência desta nova resolução SMA houve uma considerável mobilização dos empreendimentos minerários nos municípios levantados. Tal ação deve ser tomada como modelo, pelo órgão gestor, a se estender às demais bacias na região, como no caso da área estudada. 


\subsection{Recomendações para Explotação}

Esta pesquisa vem proporcionar as seguintes recomendações para a explotação:

implantação de gestão da governança de lavra: reavaliar técnicas econômicas e sócio-ambientais utilizadas, corrigindo suas próprias deficiências e aspectos negativos;

$>$ instalação de balança de pesagem: promover a quantificação dos produtos de forma a atender as necessidades do mercado e evitar enganos, na aferição de valores de produção e comercialização;

balanço de massa: incluir no planejamento a caracterização tecnológica para lotes de areia durante a fase de operação da explotação, avaliando o cascalho e finos gerados como subproduto;

monitoramento da caracterização e classificação do minério: aplicar a caracterização mineral para cada subcorpo de minério por região, assim atribuindo um tratamento direcionado para atender o tipo específico de material a ser produzido ou comercializado;

agregado com maior conteúdo tecnológico: empreender esforços para que a indústria mineral atenda satisfatoriamente às demandas atuais colocadas pelo mercado e pela sociedade, sendo necessário um contínuo esforço em pesquisas científicas e tecnológicas, assim como mais ênfase na disponibilização e disseminação de conhecimentos e técnicas já disponíveis;

$>$ produção mais limpa: desenvolver estudos no sentido de minimizar custos e desperdícios de energia em operações auxiliares e também conscientizar os futuros empreendedores quanto à gestão de resíduos e disposição dos rejeitos;

rastreamento de dragas: controlar e monitorar a evolução do sequenciamento de lavra e o desenvolvimento da atividade de beneficiamento;

> zoneamento ambiental minerário: partindo deste estudo e importância para o desenvolvimento ordenado na região, deve-se tomar como base para complementar o zoneamento para os demais recursos hídricos e áreas potencialmente econômicas para a explotação mineral, tal como a bacia dos rios Paraitinga e Paraibuna, alvo deste trabalho; 
conscientização sócio-ambiental: promover dentro dos planos de implantação, operação e encerramento do empreendimento, programas de reflorestamento e educação ambiental a serem desenvolvidos junto a instituições de ensino e também do trabalho com a comunidade para aproveitamento dos subprodutos, agregando um diferencial à sua presença no local, atuando como empresa cidadã e ambientalmente correta;

amostragem periódica: segundo a NBR NM 26/2001 (Agregados Amostragem), na fase de operação do empreendimento, pela formação de lotes de agregados; e

aproveitamento dos finos: durante a operação do empreendimento, o balanço de massa poderá direcionar o melhor aproveitamento dos finos gerados, como caso na indústria cerâmica evitando sua disposição em aterro.

\subsection{Estudos Complementares quanto à Qualidade da Areia}

O principal objetivo dos ensaios realizados no âmbito desta pesquisa foi detectar a necessidade ou não de melhorar a qualidade da areia do ponto de vista do processo de beneficiamento e ainda prescrever a realização de análises posteriores, durante a explotação ou em aplicações mais específicas, na fase de comercialização.

Assim, pelos resultados obtidos nesta pesquisa, recomenda-se que o processo de lavagem da areia seja o mais eficiente possível, com vistas à redução de matéria orgânica em futuros lotes de comercialização.

Caso não seja possível estabelecer processo de lavagem específico para este fim, na fase de explotação, então é recomendado que a aplicação da areia como agregado miúdo em concretos e argamassas seja precedida por análises complementares para:

> avaliação de efeitos da matéria orgânica ou finos argilosos na resistência mecânica, por ensaio previsto na NBR 7221/87 (Agregados - Ensaio de Qualidade de Agregado Miúdo);

avaliação pela análise petrográfica de agregado miúdo, com o objetivo de permitir sua avaliação para uso em concreto. Seguindo o método pela NBR 7389-1/2009 (Agregados - Análise petrográfica de agregado para concreto, parte 1: Agregado miúdo), que baseia-se na 
identificação e quantificação das fases minerais presentes na amostra; e avaliação de outros eventuais deletérios, principalmente em obras sujeitas a ambientes úmidos, através de ensaios que investiguem a sua suscetibilidade a reações expansivas, por exemplo com álcalis do cimento, e tomando-se por base os métodos e critérios prescritos pela NBR 7211/09. 


\section{REFERÊNCIAS}

ALMEIDA, F. F. M. Os fundamentos geológicos do relevo paulista. Boletim do Instituto Geográfico e Geológico, São Paulo, v. 41, p. 169-263, 1964.

ALMEIDA, A. S. Métodos de mineração. In: TANNO, L. C.; SINTONI, A. (Coord.). Mineração \& município: bases para planejamento e gestão dos recursos minerais. São Paulo: Instituto de Pesquisas Tecnológicas, 2003. p. 61-85. (Publicações IPT, 2850).

ANUÁRIO MINERAL BRASILEIRO. Brasília: DNPM, v. 34, 2005. 426 p.

ASSOCIAÇÃO BRASILEIRA DE NORMAS TÉCNICAS. NBR 7181: Solo - análise granulométrica. Rio de Janeiro, 1988. 13 p.

ASSOCIAÇÃO BRASILEIRA DE NORMAS TÉCNICAS. NBR 7221: Agregados Ensaio de Qualidade de Agregado Miúdo. Rio de Janeiro, 1987. 5 p.

ASSOCIAÇÃO BRASILEIRA DE NORMAS TÉCNICAS. NBR NM ISO 3310-1: Peneiras de ensaio - Requisitos técnicos e verificação. Rio de Janeiro, 1997. 12 p.

ASSOCIAÇÃO BRASILEIRA DE NORMAS TÉCNICAS. NBR NM 49: Agregado miúdo - Determinação da impurezas orgânicas. Rio de Janeiro, 2001. 3 p.

ASSOCIAÇÃO BRASILEIRA DE NORMAS TÉCNICAS. NBR NM 248: Agregados Determinação da composição granulométrica. Rio de Janeiro, 2003. 6 p.

ASSOCIAÇÃO BRASILEIRA DE NORMAS TÉCNICAS. NBR 7389-1: Agregados Análise petrográfica de agregado para concreto parte 1: Agregado miúdo. Rio de Janeiro, 2009. $5 \mathrm{p}$.

ASSOCIAÇÃO BRASILEIRA DE NORMAS TÉCNICAS. NBR 7211: Agregados para concreto - Especificações. Rio de Janeiro, 2009. 11 p. 
ASSOCIAÇÃO BRASILEIRA DE NORMAS TÉCNICAS. NBR NM 26: Agregados Amostragem. Rio de Janeiro, 2009. $10 \mathrm{p}$.

BITAR, O. Y.; FORNASARI FILHO, N.; VASCONCELOS, M. M. T. Considerações básicas para a abordagem do meio físico nos estudos de impacto ambiental. In: CONGRESSO BRASILEIRO DE GEOLOGIA, 35., 1988, Belém. Anais. Belém: SBG, 1988. p. 1974-1982.

BITAR, O. Y.; IYOMASA, W. S.; CABRAL JUNIOR, M.. Geotecnologia: tendências e desafios. São Paulo em Perspectiva, São Paulo, v. 14, n. 3, p. 78-90, jul./set. 2000.

BRASIL. Ministério do Meio Ambiente. Conselho Nacional do Meio Ambiente. Resolução CONAMA n 369 , de 28 de março de 2006. Dispõe sobre os casos excepcionais, de utilidade pública, interesse social ou baixo impacto ambiental, que possibilitam a intervenção ou supressão de vegetação em Área de Preservação Permanente - APP. Diário Oficial da União, Brasília, n. 61, 29 mar. 2006. Seção 1, p. $150-151$.

CARVALHO, N. O. Hidrossedimentologia prática. Rio de Janeiro: CPRM, 1994. $472 \mathrm{p}$.

CHRISTOFOLETTI, A. Geomorfologia fluvial. São Paulo: Edgar Blucher/EDUSP, 1988. Não paginado.

COMITÊ DE BACIAS HIDROGRÁFICAS DO RIO PARAÍBA DO SUL (CEIVAP). Projeto qualidade das águas e controle da poluição hídrica na Bacia do Paraíba do Sul, São Paulo. Resende: Agência Nacional de Energia Elétrica, 1999. 122 p. (Relatório Final do PQA da Bacia do Paraíba do Sul, Estado de São Paulo).

COMPANHIA DE PESQUISA DE RECURSOS MINERAIS (CPRM). Mapa geológico do Estado de São Paulo: escala 1: 750.000. Coord. por M. M. Perrota et al. São Paulo: CPRM, 2006. 1 Mapa. 
COMPANHIA ENERGÉTICA DE SÃO PAULO (CESP), Disponível em:

$<$ http://www.cesp.com.br/portalCesp/portal.nsf/V03.02/Empresa_UsinaParaibuna?Op enDocument> Acesso em 01 jan. 2010.

DEPARTAMENTO ESTADUAL DE PROTEÇÃO DE RECURSOS NATURAIS (DEPRN); COMPANHIA AMBIENTAL DO ESTADO DE SÃO PAULO (CETESB); POLÍCIA AMBIENTAL (PAmb). Levantamento técnico, 2007.

FERREIRA, G. C.; DAITX, E. C. Características e especificações da areia industrial. Geociências, São Paulo, v.19, n. 2, p.235- 242, 2000.

FERREIRA, G. C. Estudo dos mercados produtor e consumidor de areia industrial no Estado de São Paulo. 1995. 142p. Tese (Doutorado) - Instituto de Geociências e Ciências Exatas, Universidade Estadual Paulista, Rio Claro, 1995.

INSTITUTO BRASILEIRO DE GEOGRAFIA E ESTATÍSTICA (IBGE). Mapa topográfico Paraibuna / SP: SF-23-Y-D-II-4. Rio de Janeiro, 1973. 1 mapa. Escala 1: 50.000 .

INSTITUTO DE PESQUISAS TECNOLÓGICAS DO ESTADO DE SÃO PAULO S.A. (IPT). Mapa Geomorfológico do Estado de São Paulo. São Paulo, 1981. Escala 1:1.000.000.

INSTITUTO DE PESQUISAS TECNOLÓGICAS DO ESTADO DE SÃO PAULO S.A. (IPT). Mineração \& município: bases para planejamento e gestão dos recursos minerais. São Paulo, 2003. 177 p. (Relatório IPT, 2850).

INSTITUTO DE PESQUISAS TECNOLÓGICAS DO ESTADO DE SÃO PAULO S.A. (IPT). Minerais industriais: orientação para regularização e implantação de empreendimentos. São Paulo, 2005. 86 p. (Relatório IPT, 3000).

ISAIA, G. C.(Ed.). Concreto: Ensino, pesquisa e realizações. São Paulo: IBRACON, 2005. 2 v. 
KAHN, H. Notas de aula, 2009.

LANDSAT TM 5: imagem de satélite. São José dos Campos: INPE, 1987-1988. 1 imagem de satélite. Escala 1:100.000. canais 3,4 e composição colorida 3,4 e 5. OLIVEIRA, T. Ordenamento territorial. In The Mine, São Paulo, n. 16, p. 76-77, 2008.

PARAIBUNA (Município). Decreto $n^{\circ} 2285$, de 24 de março de 2009. Declara de utilidade pública as obras de desassoreamento do Rio Paraíba do Sul e de seus afluentes, nos trechos necessários a melhoria das condições da captação d'água para a estação de tratamento de águas do município de Paraibuna. Paraibuna: Prefeitura Municipal de Paraibuna, 2009. 2p.

PARAIBUNA (Município). Decreto n. 2416, de 23 de março de 2009. Altera a redação dos artigos $1^{\circ}$ e $2^{\circ}$ da Lei $n^{\circ} 2411$, de 27 de fevereiro de 2009. Paraibuna: Prefeitura Municipal de Paraibuna, 2009. 2p.

PROJETO RADAMBRASIL. Folhas SF.23/24 Rio de Janeiro / Vitória: geologia, geomorfologia, pedologia, vegetação, uso potencial da terra. Rio de Janeiro: DNPM, 1983. 775 p e mapas (Levantamento de Recursos Naturais; v.32).

RATTI, G. Notas de aula, 2009.

ROSS, J. L. S.; MOROZ, I. C. Mapa geomorfológico do Estado de São Paulo. São Paulo: FFLCH-USP/IPT/FAPESP, 1997. 2 v.

SÁNCHEZ, L. E. Projetos de Recuperação: Usos Futuros e a Relação com a Comunidade. Encontro de Mineração no Município de São Paulo. São Paulo, Anais. 1995. $22 \mathrm{p}$.

SÁNCHEZ, L. E. Desengenharia: o passivo ambiental na desativação de empreendimentos industriais. São Paulo: EDUSP, 2001. 254 p. 
SÁNCHEZ, L. E. Mineração e meio ambiente. In: TENDÊNCIAS tecnológicas Brasil 2015: geociências e tecnologia mineral. Ed. por Francisco Rego Chaves Fernandes et al. Rio de Janeiro: CETEM/MCT, 2007. Parte 2, capítulo 6, p. 191-208.

SANTOS, A.; OLIVEIRA, L. Venda de areia cresce em 2008. Areia \& Brita, São Paulo, n. 43, p. 22-24, jul./set. 2008.

SÃO PAULO (Estado). Secretaria do Meio Ambiente. Resolução SMA 42, de 16 de setembro de 1996. Disponível em:

<http://www.cetesb.sp.gov.br/licenciamentoo/legislacao/estadual/resolucoes/1996_R es_SMA_42.pdf> Acesso em: 03 mar. 2009.

SÃO PAULO (Estado). Secretaria do Meio Ambiente. Resolução SMA 28, de 22 de setembro de 1999. Diário Oficial do Estado, São Paulo, 23 set. 1999. Seção I, p. 19.

SÃO PAULO (Estado). Secretaria de Estado do Meio Ambiente. Atlas das unidades de conservação ambiental do estado de São Paulo: parte 2 - Interior. São Paulo: Metalivros, 1998. $30 \mathrm{p}$.

SERNA, H. A. et al. Agregados para a construção civil. Sumário Mineral, Brasília, v. 28, 2008. Disponível em:

$<$ http://www.dnpm.gov.br/assets/galeriaDocumento/SumarioMineral2008/Agregados. pdf $>$. Acesso em: 03 mar. 2009.

TEXIER, G. Visão governamental européia. In: INTERNATIONAL SEMINAR ON CONSTRUCTION AGGREGATES, 2001, São Paulo. Anais. São Paulo: ANEPAC, 2001. p. 24-28.

UNIVERSIDADE FEDERAL DE JUIZ DE FORA (UFJF). Laboratório de Mecânica dos Solos I. Disponível em: < http://www.geotecnia.uff.br/>. Acesso em: 03 mar. 2009. 
VALVERDE, F. M. Agregados para a construção civil. Balanço Mineral Brasileiro. Brasília: DNPM, 2001. Disponível em:

$<$ http://www.dnpm.gov.br/assets/galeriadocumento/balancomineral2001/agregados.p df>. Acesso em: 03 mar. 2009.

WIKIPÉDIA, Disponível em:

<http://pt.wikipedia.org/wiki/Ficheiro:SaoPaulo_Micro_ParaibunaParaitinga.svg>. Acesso em 03 mar. 2009. 